University of South Florida

DIGITAL COMMONS

@ UNIVERSITY OF SOUTH FLORIDA
Digital Commons @ University of

South Florida

1887

\title{
Contribution to the Anatomical Study of Asteroids: A translation of Contribution À L'ètude Anatomique Des Astèrides
}

Lucien Cuénot

John Lawrence

University of South Florida, lawr@usf.edu

Follow this and additional works at: https://digitalcommons.usf.edu/bin_books

\section{Recommended Citation}

Cuénot, L. (2020). Contribution to the Anatomical Study of Asteroids: A translation of Contribution $\grave{A}$ L'ètude Anatomique Des Astèrides (J. M. Lawrence, Trans.)

This Book is brought to you for free and open access by the Integrative Biology at Digital Commons @ University of South Florida. It has been accepted for inclusion in Integrative Biology Books by an authorized administrator of Digital Commons @ University of South Florida. For more information, please contact digitalcommons@usf.edu. 


\title{
THESIS
}

PRÉSENTÉS

\section{A LA FACULTÈ DES SCIENCES NATURELLES DE PARIS}

\author{
POUR OBTENIR
}

\section{LE GRADE DE DOCTEUR ÈS SCIENCES NATURELLES}

\author{
BY \\ L. CUÉNOT \\ LICENCIÉ ES SCIENCIES NATURELLES DE LA FACULTÉ DE PARIS
}

CONTRIBUTION À L’ÈTUDE ANATOMIQUE DES ASTÈRIDES.

Soutennes le 11 novembre, devant la Commission d'Examen

HEBERT, Président

DE LACAZE-DEUTHIERS, Examinateurs, BONNER 


\title{
THESIS
}

PRESENTED TO

TO THE FACULTY OF SCIENCES OF PARIS

TO OBTAIN

THE DEGREE OF DOCTOR IN NATURAL SCIENCES

\author{
BY \\ L. CUÉNOT \\ LICENCIÉ IN NATURAL SCIENCES FROM THE FACULTY OF PARIS
}

\section{CONTRIBUTION TO THE ANATOMICAL STUDY OF ASTEROIDS}

Defended November 11, before the Examining Committee

\author{
HEBERT, President \\ DE LACAZE-DEUTHIERS, Examiners \\ BONNER

\section{POITIERS} \\ TYPOPGRAPHIE OUDIN \\ 4, RUE DE L’ÉPERON, 4


Translator's note:
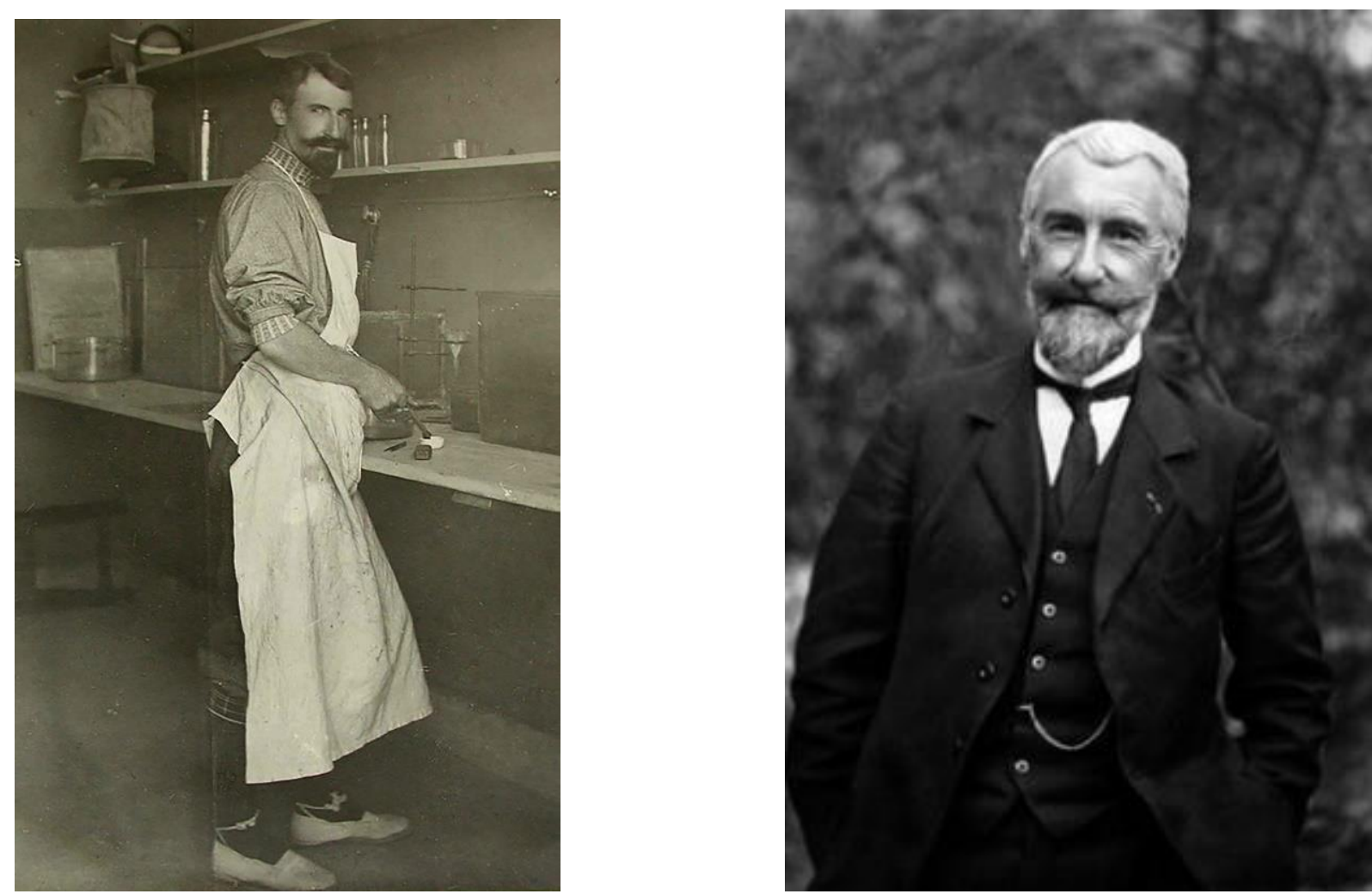

Lucien Cuénot 1906

Lucien Claude Marie Julien Cuénot (21 October 1866-7 January 1951). Cuénot was a student of Lacaze-Duthiers at the Faculty of Sciences of the Sorbonne. He received his licentiate in 1885 and his docteur ès sciences naturelles degree in 1887 at age twenty-one with his thesis on asteroids.He was appointed to to the Faculty of Sciences of Nancy in 1890. He was appointed a full professor in 1898 and remained at the university until he retired in 1937. Although he had broad interest in evolution and adaptation, he continued an interest in echinoderms He published a major memoir on the morphology of echinoderms in 1891 and a synthesis on echinoderms in 1948.

Cuénot, L. 1891. Ètudes morphologiques sur les Echinodermes. Archives de Biologie. 11, 33-681. Cuénot, L. 1948. Anatomie, éthologie et systématique des échinodermes. In: Grassé, P.-P. (Ed.) Traité de Zoologie. 11. Masson et Cie., Paris., pp. 3-272.

Cuénot is not known in the scientific world for his work with echinoderms, but is famous as a genetist. In 1905, his work with inheritance of coat color in mice proved that Mendelism applied to animals as well as plants.

Several of Cuénot's anatomical terms have no exact correspondence to contemporary terms. E.g., "glandes lymphatique" (lymph glands). Currently lymph glands in humans are considered to 
function by filtering foreign particles and by producing white blood cells and cells involved in the immune response. Cuénot's description is understandably more limited. He says the lymph glands are the site of production of blood corpuscles. He does not distinguish between blood corpuscles and lymphocytes: "Origin of blood corpuscles or lymph corpuscles." His usage of the term is sometimes difficult. E.g., "les branchies lymphatiques", literally lymphatic gills. These are the papulae. Cuénot does not state they produce blood cells. Cuénot' apparently called them lymphatic because they contain a fluid, lymph, that was not blood. Michel Jangoux has advised me this was common in the nineteenth century. I have retained Cuénot's "lymph gland". The difference in usage of lymph gland by Cuénot in the latter part of the nineteenth century and now should be noted.

Another example of Cuénot's usage that is not used today is "embryonnaires". He used the term not only for cells of the embryo but for undifferentiated cells of post-metamorphic individuals.

Cuénot used the system of Lacaze-Duthiers, which oriented all echinoderm classes to that of crinoids: the upper surface as the oral surface, the lower surface as the aboral surface. He states "In my descriptions, I shall always place the asteroid by the method adopted by de LacazeDuthiers, the mouth above and the aboral pole below, so that the vertical axis, comparable to the long axis of a holothuroid, goes from the middle of the mouth to the center of the opposite surface. The surface on which the animal is lying, generally called the ventral surface, will be the upper surface. The dorsal surface of authors will be the lower surface.I have not changed his terminology." E.g., he states "When one examines the upper or oral surface of an asteroid...." This should be remembered when Cuénot refers to the asteroid's orientation.

Cuénot's Bibliography is idiosyncratic. Variation in style is obvious. The title of one of Carpenter's citations is in French. I have not changed anything in the Bibliography. The form of the descriptions of the plates also is variable and I have not changed them.

I thank Constance Rinaldo, Librarian of the Ernst Mayr Library and Museum of Comparative Zoology Archives at Harvard University and Janessa Cobb Fletcher, Fish and Wildlife Research Institute, Florida Fish and Wildlife Conservation Commisssion for their help with the Plates. 


\title{
TO LACAZE-DUTHIERS
}

\section{MEMBER OF THE INSITUTE}

\author{
PROFESSOR OF ZOOLOGY, ANATOMY AND COMPARATIVE PHYSIOLOGY OF THE FACULTY OF \\ SCIENCE \\ $\mathrm{V}$
}

\section{DEAR AND HONORED MASTER.}

Please accept the homage of this thesis as a small tribute to the gratitude I owe you. It was you who made me love zoology. It is you who, by your constant benevolence, allowed me to continue my studies in your laboratories. I owe you everything and cannot prove my gratitude to you except by my work. My only ambition is to make myself worthy of such a master, and to hold a place, however small, in the rich constellation of zoologists you have given to France.

\section{Cuénot}




\section{BIBLIOGRAPHY}

1. Agassiz (A.). Embryology of the Starfish. Contrib. Nat. Hist. U.S., vol. V, 1861.

2. ----- North American Starfishes, Memoirs of the Museum of Comparative Zoology at Harvard College, Cambridge Mass, vol. V. $\mathrm{n}^{\circ} 1,1877$.

3. Baudelot. Etudes générales sur le système nerveux, Arch. Zool. exp., tome I, 1872, pag. 177.

4. Bell. Note sur l'Asterias glacialis et les espèces alliées, Zool. Anz., juin 1882, analysé dans Arch. Zool. exp., tome 10, $1^{\text {re }}$ série, 1882, Notes et Revues, pag. LIX.

5. Carpenter $(\mathrm{H})$. The minute Anatomie of the Brachiate Echinoderms (The Quaterly Journal, avril 1884).

----- Sur les relations anatomiques du system vasculaire chez les Echinodermes (The Quaterly Journal, oct. 1883, pag. 537), analysé dans Arch. Zool. ep., tome 2, $2^{\text {me }}$ série, 1884. Notes et Revues, pag. XIX.

----- Notes sur la morphologie des Echinodermes (The Quaterly Journal, avril 1881, analysé dans Arch. Zool. exp., tome 3, $2^{\text {me }}$ série, 1885, Notes et Revues, pag. I.

6. Chiaje (della). Memoria sulla Storia et Notomia degli animali senza vertebre, etc., vol. II, 1825.

7. Desor. Uber die Entwickelung der Asteriden, Müller's Arch. für Anat., 1849, pag. 70.

8. Dujardin et Hupé. Zoophytes, suite à Buffon.

9. Duvernoy. L’Institut, 1837, pag. 208 (Société d'Histoire naturelle de Strasbourg).

10. Sur l'analogie de composition et quelques points de l'organisation des Echinodermes, Mém. l'Acad. des Sciemces, 1849, Vol. XX, pag. 579.

11. Fœttinger. Sur l'existence de l'hémoglobine chez les Echinodermes, Archiv. de Biologie, tome 1, p. 105.

12. Fol (H.) Recherches sur la fécondation et le commencement de l'hénogénie chez divers animaux, Genève, 1879, Mémoires de la Société physique et d'hist. nat. de Genève, tome XXVI.

13. Gaudry. Squelette buccal des Stellérides, Ann. Sc. Nat., 1851, tome XVI, $3^{\text {me }}$ série, p. 339.

14. Geddes. Sur le fluide périviscéral des Oursins, Arch. Zool. exp., tome 8, $1^{\text {re }}$ série, 1879, p. 483.

15. Giard. Particularités de reproduction de certains Echinodermes en rapport avec l'éthologie de ces animaux, Bulletin scientifique du dép. du Nord, $1^{\text {re }}$ année, $2^{\text {me }}$ série, 1878, pag. 296.

16. Greeff. Ueber den Bau und die Entwicklung der Echinodermen, Sitzungsbericht der

Gesellschaft zür Beford. der ges. Naturw. zu Marburg, 1871-79.

17. Hæckel (E.). Ueber die Augen und Nerven der Seestern. Zeitschrift für wiss. Zool., tome 10, 1860, pag. 183.

18. ----- Die Kometenforme der Seesterne und der Generation wechsel der Echinodermen, Zeitschrift: für wiss. Zool., tome 30, 1878, pag. 124; analysé dans Arch. Zool., exp., tome 6, $1^{\text {re }}$ série, 1877, Notes et Revues, pag. XXXIII.

19. Hamann. Beiträge zur Histologie der Echinodermen, Zeitschrift für wiss. Zool., tome 39, 1883, pag. 145.

20. ----- Beiträge zur Hist. der Echin., Heft 2. Die Asteriden, Jena, 1885. 
21. Herapath. On the pedicellariae of the Echinodermata, The Quaterly Journal, 1865, pag. 175.

22. Hoffman. Zur Anatomie der Asteriden, Nederlandisches Archiv. für Zool., 1874-75, Band II, pag. 1.

23. Howell. Note on the presence of Hœmoglobin in the Echinoderms, John's Hop. Univ. Stud. Biol. Lab., vol. 3, no ${ }^{\circ}$ 6, pag. 289.

24. Huxley. Report upon the Researches of Prof. Müller into the Anatomy and develop. of the Echinoderms, Ann. and Mag. Nat. Hist., vol. VIII, 1854, pag. 1.

25. Jourdain. Sur les yeux de l'Ast. rubens, Comptes-Rendus de l'Acad. des Sc., tome 60, 1865 , pag. 103.

26. ----- Recherches sur l'appareil circulatoire d'Ast. rubens, Comptes-Rendus, tome 65, 1867, pag. 102.

27. ----- Sur les voies par lesquelles le liquid seminal et les oeufs sont évacués chez l'Asterie commune. Comptes-Rendus, tome 91, 1882, pag. 714.

28. Kowalewsky. Zeitsch. für wiss. Zool., tome 22, 1872, pag. 283.

29. Lacaze-Duthiers (H. de). Sur une forme nouvelle et simple du proembryo des Echinodermes (Stellérides, Asteriscus verruculatus, M. et Tr.), Comptes-Rendus, tome 78, 1874, pag. 24.

30. Lange (W.). Beiträge zur Anatomie und Histologie der Asterien und Ophiuren, Morph.

Jahrb., Bund II, 1876, pag. 246.

31. Lóven. Etudes sur les Echinoidées, Kongl. Svenska Vetenskaps Akademiens, Handlingar, Bandet II, $\mathrm{n}^{\circ}$ 7, Stockholm, 1875.

32. Ludwig (H.). Beiträge zur Anatomie der Asteriden, Zeitsch. für wiss. Zool., Band 30, 1878, pag. 99.

33. ----- Zur Kenntniss der Gattung Brissinga, même recueil, Band 34, p. 216.

34. ----- Ueber die Genitalorgane der Asterina gibbosa, Bd. 31, pag. 395.

35. ----- Entwicklungsgeschichte der Aserina gibbosa, même recueil, Bd. 37, 1882, pag. 1.

36. Lutken. Description de quelques Ophiurides nouveaux ou peu connus, avec quelques remarques sur le division spontanée chez les Rayonnés, Oversigt over d. k. D. Selsk. Forhandl. O. S. V., n² 2, Kjöbenhaven, 1872.

37. Von Martens. Ueber ostasiatische Echinodermen, Arch. für Naturg, tome 32, Band I, 1866, pag. 66.

38. Mettenheimer. Ueber die Gesichtorgane des violetten Seesterns der Ostsee. Müller Arch., 1862, pag. 210.

39. Muller (Joh.). Anatomische Studien über die Echinodermen, Archive für Anat., Phys. und wiss. Medicin, 1850, pag. 117.

40. ----- Ueber den Bau der Echinodermen, Berlin, 1854.

41. Müller et Troschel. System der Asteriden, Braunschweig, 1842.

42. Owsjannikov. Ueber das Nervensystem des Seesterne, bulletin de l'Académie de St-

Petérsburg, nov. 1870, pag. 310.

43. Perrier (Ed.). Recherches sur les pédicellaires et les ambulacraires des Astéries et des

Oursins, Ann. Sc. Nat., tomes 12 et 13, 1869-70.

44. ----- Même sujet, response à M. A. Agassiz, Arch. Zool. exp., tome 3, $1^{\text {re }}$ série, 1874, Notes et Revues, pag. VII.

45. ----- Recherches sur 1'appareil circulatoire des Oursins, Arch. Zool. exp., tome 4, $1^{\text {re }}$ série, 1875, pag. 605.

46. ----- Revision des Stellérides du Muséum, Arch. Zool. exp., tomes 4 et 5, $1^{\text {re }}$ série, 1875-76. 
47. Perrier (Ed.). Sur une Astéride des grand profondeur de l'Atlantique pourvue d'un pédoncule dorsal. Comptes-Rendus, tome 95, 1882, pag. 13-79.

48. ----- Sur l'organisation des Crinoïdes, Comptes-Rendus, tome 97, 1883, pag. 187.

49. ----- Resumé de recherches sur l'organogénie et l'anatomie des Comatules. Zool. Anz, 12 février, 1885.

50. ----- Comptes-Rendus, tome 102, 24 mai 1886, pag. 1146.

51. ----- Sur les corps plastidogène ou prétendu cœur des Echinodermes, Comptes-Rendus, tome 101, 17 janvier1887, pag. 180.

52. Perrier et Poirier. Sur l'appareil circulatoire des Etoiles de mer, Comptes-Rendus, tome 94, 1882, pag. 658.

53. ----- Sur l'appareil reproducteur des Etoiles de mer, Competes-Rendus, tome 94, 1882, pag. 894.

54. Romanes et Ewart. Observations on the Locomotor System of Echinodermata. Phil. Trans., 1881, pag. 810.

55. Rymer Jones. Zur Naturgechichte der Asteriden, Fror. Not., Bd. 42, n 248, 1839.

56. Sars (G.-O.). Uber die Entwickelung der Seesterne (Fragment aus meinen "Beitragen zur Fauna von Norwegen"), Arch. für Naturg., tome 19, 1844, pag. 162.

57. ----- Researches on the structure and affinity of the genus Brisinga, Christiania, 1875.

58. Semper, Reisen im Archipel der Philippinen, 1868, II, Holothurien, pag. 148.

59. Von Siebold. Zur Anatomie der Seesterne, Müller's Arch., 1836, pag. 291.

60. Simroth. Anatomie und Schizogonie der Ophiactis virens, Zeietsch. für wiss. Zool., tome 28, 1877, pag. 419.

61. Sladen. Annals and Mag. of Nat. Hist., août 1880, pag. 101.

62. Studer. Echinodermen aus den antartischen Meere, Monatsber der Berlin Akad., 1877, pag. 457.

----- Uber Geschlechts dimorphismus bei Echinodermen, Zool. Anz., 1880, n 67 et 68, pag. 523 et pag. 543.

63. Spix. Mémoire pour server à l'histoire de l'Asterie rouge, de l'Actinia coriacea (Cuv.), et de l'Alcyonium exos, Ann. du Muséum, tome XIII, 1809, pag 438.

64. Teuscher. Beitrage zur Anatomie Asteriden, Jenaische Zeietsch. fûr Naturw., Bd. X, 1876, pag. 493.

65. Tiedemann. Anaatomie der Rohron-Holothurie, des pommeranz farbigen Seesterns und Steinseeigels, Landshut, 1816.

66. Viguier. Squelette buccal des Stellérides. Arch. Zool. exp., Notes et Revues, tome 8, 18791880 , pag. 1.

67. ----- Squelette des Stellérides, Arch. Zool. exp., tome 7, $1^{\text {re }}$ série, 1878, pag. 33.

68. Volkmann. Ueber des Gefässystem der Seesterne, Isis, 1837, pag. 543.

69. Carl Vogt et Yung. Traité d'Anatomie comparée, $9^{\text {me }}$ livre son.

70. Vulpian. Leçons sur le physiologie générale et comparée du système nerveux, Paris, 1866.

71. Williams. On the use of the sandcanal of Starfishes. Ann. of Nat. Hist., $2^{\text {me }}$ série, vol. 19, 1857, pag. 55.

72. Wilson. The nervous system of the Asteriden. Transactions of the Linnean Society, 1862, tome 23 . 
We shall complete this list, already very long, with the bibliography of Mûller and Troschel (System der Asteriden) that contains all the works prior to 1841 and with that of Perrier (Revision des Stellérides) that is especially concerned with the classification of these animals.

I have indicated each work by an ordered number. In this work, I shall cite simply the number. Reference to this bibliographic list will give all the necessary information. 


\title{
CONTRIBUTION
}

TO

\section{THE ANATOMICAL STUDY}

OF

\section{ASTEROIDS}

BY

\author{
L. CUÉNOT \\ LICENCIÉ IN NATURAL SCIENCES OF THE FACULTY OF PARIS
}

\section{INTRODUCTION}

Asteroids have been the subject of numerous studies, in France, in England and in Germany. However, no point of their organization is without uncertainty. The nervous system, the water vascular system, the genital organs are especially the subject of the most eager discussions. All the studies that have been published absolutely lack generalizations, concerning only one or two species. Moreover, their authors have used exclusively either dissections and injections or sections. Perhaps there is no animal in which both procedures are more necessary than in the echinoderms As de Lacaze-Duthiers has correctly said, one should explore first fine dissection and injections, then to verify the results by means of sections with diverse histological methods. I have sought to make in this work different conditions than those in preceding studies. I accept a character as true only when the anatomy, sections and dissections agree. Moreover, I have been 
able to study eighteen species of twelve different genera from the ocean, the Mediterranean and the Red Sea. This gives my results sufficient generality.

It is usual, at the beginning of a work, to give the history of the question I have preferred, as I go, to cite the opinions of the different authors. This avoids continuous repetition and tedious numbering.

This memoir has been done entirely in the laboratories of experimental zoology of de Lacaze-Duthiers. I began it at the Sorbonne, then to continue and finish in two visits to the seashore. I have been able thus to study the asteroids of the ocean at Roscoff and those of the Mediterranean at Banyuls. I must thank my dear master for accepting me into his laboratory where I found such a generous hospitality and for having helped me with his excellent advice that brought my study to a good end; that he receives the expression of my deepest appreciation.

I must also thank Dr Faurot, who entrusted to me the asteroids that he collected on his mission to the Red Sea, Ed. Fournier and several of my friends who helped me in various ways.

\section{Orientation}

In my descriptions, I shall always place the asteroid by the method adopted by de LacazeDuthiers, the mouth above and the aboral pole below, so that the vertical axis, comparable to the long axis of a holothuroid, goes from the middle of the mouth to the center of the opposite surface. The surface on which the animal is lying, generally called the ventral surface, will be the upper surface. The dorsal surface of authors will be the lower surface. It corresponds in regular urchins to the periproct with its ten calcareous plates, etc, in the opposite direction of my predecessors. Sections of the madreporite are placed as usual. This does not have any great morphological importance because the madreporite or the pores that represent it is very variable in position in the various echinoderms.

In their exterior form, the asteroids never have bilateral symmetry with an anteriorposterior plane, as in spatangoids for example. Agassiz, Lovén and Ludwig have given three different theories on this subject. That of Lovén seems to me to be the true one. But as it can be applied only to asteroids with 5 arms, some complementary studies seem indispensable to me. Moreover, in an anatomical work, fixation of the anterior-posterior plane does not have great utility.

\section{Connective tissue and muscular tissue}

It is difficult to describe the histology of different organs without having precise understanding of the connective tissue. I thus am going to make a complete histological study.

When one makes sections of very young asteroids or ophiuroids, one sees that the nonepithelial tissues are nearly exclusively cellular. They are formed of cells with a large nucleus, containing a very refractive nucleolus. The protoplasm is very granulose. Most of the connective tissue comes from these cells.

Connective tissue or undifferentiated cells. - Many of these original cells do not change. They remain either separated or agglomerated, sometimes in large numbers. These more or less spherical masses are up to 24 to $45 \mu$ in diameter. There are many of them in the integument of Asterias glacialis and Asterina gibbosa, in the connective tissue layer of the tube foot, etc. (see pl. I, fig. 12, $f$, and pl. II, fig. 2). 
Hamann has not interpreted these cellular masses in any way. He makes it the epithelial covering of a lacunar system particularly developed in the wall of the body. I shall return to it in regards to circulation.

A large number of these cells remain isolated. One sees them in abundance in all sections of the integument. Often they remain spherical with their nucleus located laterally (pl. II, fig. 2). Often they have more or less numerous extensions formed of very granular protoplasm (pl. II, fig. 3) that can anastomose. In this form, they show well the star-shaped connective tissue cells so developed in some animals, the mollusks for example (Fleming). In young asteroids that he studied nearly exclusively, Hamann has seen these cells and figured them very accurately.

Up to now the cell is scarcely changed. They can be recognized very easily. The second type is fibrous. These have fibers sometimes very long, very thin, homogeneous and stained strongly with carmine. They have a beautiful round nucleus with a nucleolus surrounded by some protoplasmic granules (pl. II, fig. 4). They are easily recognized. In general, these fibers are very loosely connected. They are found in all organs that have great changes in form (tube feet, ampullae, papulae, etc.). Often they have a spiral form when a part of the contracted organ is fixed with reagents (pl. II, fig. 5). Hamann was the first to describe accurately these fibers. I think they can compare them physiologically to the elastic fibers of higher animals.

One can recognize a very clear derivation of the undifferentiated cell that has served as a point of origin. The third type of connective tissue cell is very elongated. They have very fine long fibers that are stained a bright pink by picrocarimine. They have small fusiform nuclei. I have not been able to see the nucleolus (pl. II, fig. 6; pl. I, fig. 1 and 2,f). They are found in the organs that have great resistance, in the mesentery, the fibrous peduncle of crossed pedicellaria of the genus Asterias. This form of fibrous connective tissue has been often mistaken for muscle fibers (Herapath, Perrier). It is very clearly distinguished by all its characters, its staining by reagents, its mode of insertion, etc.

Finally, the last form of connective tissue and the most frequent is the fundamental substance, very compact fibrous felt. It is very elastic, perfectly homogeneous to the naked eye. When it has been hardened by different alcohols, it becomes extremely strong and is a great obstacle to making sections. This fibrous substance is stained very irregularly by carmine. It is first transformed by boiling into a brownish material that has the aspect and consistency of elastic gum, then it becomes friable and gelatinous without becoming soluble in water. This distinguishes it from gelatin and chondrin.

In very thin sections, there are in places small oval nuclei distributed irregularly (pl. II, fig. 7). In vivo or in sections not hardened by alcohol, this substance appears like a very dense felt made of very fine fibrils in bundles. Finally, it can contain many undifferentiated cells (Asterina gibbosa). When an animal becomes weakened, this tissue dies first and decomposes into nacreous fibers that are very well known to those who have kept asteroids or holothuroids alive in aquaria. This fibrous substance is found in all organs of asteroids. The integument of culcitids is formed entirely of it, to a thickness of 15 to $20 \mathrm{~mm}$, which explains its great elasticity.

Calcareous framework - The calcareous tissues has always been very badly described. It is composed of fundamental substance with numerous undifferentiated cells. The fundamental substance forms more or less dense meshes, but which are never regularly arranged as in the spines of an urchin. On these types of mesh especially at the intersections, are numerous undifferentiated cells. Often these latter are interconnected and one only sees then protoplasmic tracts following the path of the connective tissue substratum with many nuclei where the meet (pl. II, fig. 8). The calcite is absolutely localized in the fibrous fundamental substance. The undifferentiated cells have 
scarcely any role in its formation. They are mummified, so to speak, in the interior of the mineral layer. The connective tissue has very diverse appearances that explains the divergence of opinion on its constitution.

Muscle fiber. - As a comparison term, I am going to describe the muscle fiber, whose character have been recognized in asteroids and holothuroids by Hamann and Jourdan.

It is large and very long, often bifurcated, entirely smooth and homogeneous, never having any trace of striation in either direction. It is stained pale pink by carmine, but in pieces fixed with picric acid, it has a golden yellow tint that makes it very easy to distinguish from connective tissue, always brightly colored. The nucleus, located in an indentation of the fiber, is large, very clear, with a nucleolus. Some protoplasmic granules connect the nucleus to the fiber (pl. II, fig. 10).

The muscle fiber has very conspicuous characters that does not allow it to be confused with a fibrous connective tissue cell. The muscle fibers are never in communication with the ectodermal cells, as Hamann suggested. They result from the direct transformation of an undifferentiated cell that has a very elongated fiber. They have the same properties of irritability as those of higher animals. Physical agents, pricks, acids, etc. make them contract. If one gently touches an internal organ such as a Polian vesicle or a tube foot ampulla with a needle, circular muscle fibers at the point of contact very strongly contract to nearly close the lumen of the organ. Everywhere where there are muscles (axial hemal sinus, stomach caecae, mesenteries, etc...), a simple prick will make them contract. This observations makes it possible to understand how Tiedemann and Hoffmann were led to be wrong on the subject of the contractions of the heart (axial gland). They mistook the movement of mesenteric fibers for a true cardiac systole.

Enigmatic yellow bodies. - Principally in preparations of the axial gland, in the midst of normal cells, are found rounded corpuscles, with fine granules of 7 to $10 \mu$. In preparations with osmic oxide, they are greenish yellow, looking a little like the color of chlorophyll, and appear surrounded by a transparent membrane. In sections stained with picrocarmine, the have a bright yellow color. I have not seen a nucleus (pl. VIII, fig. $8 a$ ). I have found them in very large numbers in the axial gland and its extensions. Hamann reported identical corpuscles (Körnerzellen) in a section of the intestine of Cucumaria Planci (19, pag. 151). These formations do not appear to me to belong to the animal itself. They are perhaps vegetable cells (zooxanthellae, zoochlorellae).

\section{Integuments.}

The integuments of asteroids have some aspects completely different according to the species. Of extremely variable thickness, whose two extremes are the culcitids and palmipids, incrusted with calcite forming variably arranged plates, they have appendages that can be placed in three categories: spines, pedicellariae and papulae. The spines are very variable and provide good characters for identification. The pedicellariae, small grasping organs, are considered characteristic for each species, but a large number of asteroids lack them. Finally, the gills, respiratory organs, exist in all groups and have a great conformity in structure.

The integument always has three layers: an internal one formed by the epithelium of the perivisceral coelom, a middle connective tissue one, and an external one formed of an epithelium with very tall cells. It is in the middle layer and in its most external parts that the calcareous plates of the body are formed, as in the holothuroids.

The peritoneal epithelium is formed of flat cells that have a projecting nucleus in the sections. They are easily impregnated with silver nitrate with precautions to prevent formaton of silver chloride. There is then a mosaic of polygonal cells, more or less dense according to region 
that is impregnated. It is completely like the peritoneal epithelium of vertebrates and annelids (pl. II, fig. 9). The nucleus is large, irregular and nucleolated. These flat cells cover all the diverticula of the perivisceral coelom and all the internal organs.

The external epithelium is formed of very tall, elongated cells. They are covered by a thick cuticle and have cilia. These cells have a thin one part of which is attached to the underlying connective tissue and the other supports the overlying cuticle. A spherical or oval nucleus surrounded by a small quantity of protoplasm projects from the surface of this filament that represents the body of the cell (pl. 1, fig. 12). To study this epithelium better, it is necessary to shred it after staining with osmic acid in carmine $(*)$.

The entire cellular layer appears to be mixed to form a continuous cuticle. It is not so. One can completely impregnate the surface with silver and show that they are simply juxtaposed in the cuticular layer. We do not see the pores through which the cilia pass. The cells are separated from each other in a way to provide from place to place empty spaces so regularly arranged that one could believe in glandular bodies. But nothing appears by the various modes of preparation. This leads me to conclude that they are simply vacuoles between the cells.

Two types of glandular cells are found in these undifferentiated cells. They are very well developed especially in Asterias glacialils. Some are mucous glands. These are large cells stained slightly gray in osmic acid. The nucleus is lateral or sometimes in the base of the cell. It is sometimes on a pedicle (pl. I, fig. 23), sometimes resting by its base on the connective tissue layer (pl. I, fig. 12, q).

The others, more frequent, have, in the mature state, a muriform mass like a cluster, supported by a thin pedicle with a nucleus (pl. I, fig. 12, 18, 23, m). Each grain of this cluster is round, slightly refringent, slightly yellow in the living state. The cluster is stained like lees of wine by osmic acid in carmine. Often the young state is found mixed with these. They have in the interior a polygonal protoplasmic system, sometimes very apparent, other times only fine granules (pl. I, fig. 13 and fig. $23, m$ ). The protoplasmic meshes indicate the location of yellow vesicles expelled by the cell. The granular form was seen by Hamann, but I repeat, this is not at all the final state of the cell. The mucous cells secrete abundant mucus when the asteroid is stimulated. As for the muriforom cells, I attribute a defensive role to them, a physiological similarity to the nematocysts of coelenterates. I shall discuss them again in regard to the pedicellariae.

Muriform cells are fouond in Astropecten, Echinaster sepositus and Asterias. They are much rarer in the other species. The mucous cells, very numerous in Asterias and Astropecten, are less frequent in the other asteroids.

We know the magnificent colors of some asteroids. The red orange of Astropecten aurantiacus as indicated by its specific name, the bright red of Echinaster sepositus, etc., are due to a special pigment. The red pigment is found in the cells of the external epithelium, in the form of small granules. It resists the action of osmic acid, but disappears in nitric acid and $90 \%$ alcohol. The pigmented cells, after the destruction of their principal pigment, have a protoplasm filled with granules (pl. I, fig. $18 \mathrm{c}$ ), which shows that each grain of pigment has a protoplasmic substrate. The other integumentary pigments (violet, etc.) are also contained in epithelial cells,

Between the bases of these diverse cells is a fibrous layer that is the superficial nerve plexus (pl. I, fig. 12, 18, 23, $n$ ).

The composition of this epithelium remains identical on the upper surface and on the lower surface. It covers all the appendages, gills, pedicellariae or spines. It is interrupted only on the organs exposed to abrasion such as the top of the spines. Above, it is continuous with the epithelium of the ambulacral groove and that of the digestive tract. 
The two epithelial layers, internal and external, are separated by connective tissue in all its forms. The fibrous fundamental substance is the most important (culcitids). The calcareous nodules with extremely diverse forms fills the external part. However, in culcitids, there are some rods located on the internal surface. This is in relation to the exceptional thickness of the body wall. The spines are always articulated on the calcareous masses (pl. I, fig 20,p).

The external epithelium is sometimes applied directly on the fibrous substance. But in the species whose skin is not rigid (Ast. glacialis, Ech. sepositus, Asterias gibbosa), there is a thick interpolated layer of elastic fibrils (pl. I, fig. 15, $f$ ).

Finally, there is in all sections, between this connective tissue layer and the peritoneal epithelium, a more or less thick muscle layer, arranged in every direction, but most often parallel to the direction of the arm. These fibers are dependencies of the radial muscle cord. They extend into the mesentery straps that connect the digestive tract to the body wall. They allow the body wall to exert some pressure on the perivisceral fluid that results in protrusion of the papulae, evagination of the stomach outside the animal, etc. When an arm is broken, either by autotomy or by accident, it is likewise these fibers that close the wound by bringing together the lower and upper walls of the arms.

Dermal glands of Echinaster sepositus. - This magnificent star, a beautiful red, that ornaments the aquaria at Banyuls, has a unique peculiarity in asteroids. In addidtion to the muriform cells that are distributed irregularly in the external epithelium are true glands embedded in its dermal wall, especially in the region of the papulae and towards the end of the arm. Teuscher discovered them (64), but described them poorly.

When we examine a living Echinaster at high magnification, we see that all the skeletal part is covered by a thick dermal layer that is only slightly resistant. When stimulated from place to place with a needle, we see its design of small pores and a drop of mucus comes out of the opening. This mucus is ropy and can be removed easily with forceps. It is usually opalin, sometimes slightly colored violet. An examination at a high magnification (oc. 2, obj. 9 to $1 \mathrm{~mm}$, Nachet) shows that it composed of an infinity of transparent vesicles, from 5 to $6 \mu$. Some are violet, sometimes a red yellow. We find the cells of the gland projected by the pressure exerted on the skin.

We find these glands easily in sections (pl. I, fig. 15). They have a very irregularly form (1/2 mm in length) and more or less spherical. They are embedded in the sub-epidermal fibrous tissue that forms a kind of a sheath. The orifice is a shallow depression. The external epithelium ends at its borders. The gland is formed of a connective tissue stroma, composed of a wide mesh circumscribing ovoid spaces (pl. I, fig. 16, f). In each mesh is a voluminous cell that is the interesting part of the organ. The vesicles produced by its activity are at its borders or in the connective tissue (pl. I, fig. 16, v). The nucleus is also at the periphery. But, to better understand their constitution, it is necessary to shred it after staining with osmic acid in carmine. The glands are so numerous that in treating an epidermal fragment, one always finds easily recognizable glandular cells. They are from 27 to $38 \mu$, with extremely granular protoplasm, generally round or ovoid, sometimes with extensions. Their form evidently depends on the connective tissue mesh that contains them. The nucleus is small relative to the volume of the cell (pl. I, fig. 17, g). One sees it moving towards the periphery, flattening, perhaps even to move outside. In fact, one finds a large number of free nuclei in the gland (fig. 17, $n$ ). In the interior of the cell one sees clear areas that are only the vesicles. They are sometimes free, most often connected in a central mammelated mass formed of irregular sacs made polyhedral by reciprocal compressions. They look like a wall with refringent angles that are not colored by picrocarmine. The interior liquid is very pale pink. 
Sometimes a large part of the cell is filled by a mass of vesicles. The cell is thus entirely transformed (fig. 17,v), the nucleus alone remains surrounded again with protoplasm and recommences the same cycle. As for the vesicles that are produced, they are little by little expelled in reaching the opening by a kind of propulsive force.

The vesicles produced by this gland of Echinaster sepositus are formed of the same substance as the muriform cells that I described in the external epithelium of asteroids. They respond in the same way to reagents. This leads us to consider them as having the same defensive function. I shall talk of it again after the pedicellariae.

Skeleton, muscles. - Detailed conditions on this subject can be found in the work of Viguier (67). This author has studied the skeleton in numerous genera and has even deduced a classification from it. I shall present my observations on this subject in regards to classification. As for the odonntophore, that Carl Vogt and Yong still consider, like Meckel, as a modified supporting ambulacrum, I take the opinion of Viguier who considered it as a special piece. But he did not give it any role. It seems to me that this piece has a completely mechanical function. It is what separates the ambulacral pieces between which it is solidly encased. Thanks to it, in all the movements of the animal, the mouth keeps its regular form. Finally, it can be seen, when the living animal is observed and not the dried one, the interbrachial support in all is the odontopore, either the support is very small (Astropecten, Echinaster) or that it is of great importance (Culcita, Asterina, Asterias). The odontophore plays a little the role of a keystone in relation to the peribuccal pieces. It is on it that the interbrachial septum takes a solid insertion. All this leads me to replace the name odontophore that is unfortunate. First of all it has no teeth in the asteroids, because the pieces to which we have given this name have no masticatory function. Then the odontophore does not have them because it is supported by them. It seems to me that the name of interradial support, indicatingp its position and a little its function, would be preferable.

Lovén has compared the skeleton of asteroids to that of urchins based on the study of the young. He has shown in a precise faction that the lower part of the arms and disk of asteroids corresponds to the periproct of the urchin with 10 calcareous plates. The ocular plates (radials of Lovén) between at the end of the arms, the genital plates (costals of Lovén) persist on the disk (one being transformed into the madreporite, as in the urchin). This is especially visible in Asterina gibbosa, whose apical pole has an appearance recalling that of the urchin. It is regrettable that Vignier has not taken the theory of Lovén as the basis for his descriptions and that he has not sought to find the genital or costal plates in the asteroids he studied in his work, otherwise excellent and of great accuracy.

\section{Papulae}

When a live Asterias glacialis is examined in an aquarium, one sees that the entire surface of the disk and the arms is covered with small bunches of transparent caeca that nearly hide all the other appendages of the body. When one touches these caeca with the point of a needle, one sees them quickly contract, to protrude soon after (pl. VIII, fig. 11, br). These are the papulae (Hauatkiemen, Kiemenblascen of the Germans, tubules of Carl Vogt and Yung).

They can be described as a portion of the body wall that has become very thin. It has special muscles and is extended by pressure of the liquid of the coelom. These papulae exist in all asteroids and are characteristic of the family. They are found in the intervals between the calcareous pieces of the skeleton. They are missing where the body wall is exposed to abrasion, the upper surface, 
for example. This is especially clear in the pentagonal species (Asterina gibbosa), whose oral surface completely lacks them.

An examination of a vertical section of these papulae shows (pl. I, fig. 20, 21, 22) that they have three layers, extensions of those of the body wall. Hamann (20) was the first to describe a small cellular thickening of the internal layer (pl. I, fig. 21) at the top of the gill. This is the thickest part because it is there that the strongest pressure is exerted on the papula under the action of the liquid of the body cavity. When one presses on one of the arms to cause the liquid to flow elsewhere, often the papulae give in to the stress and burst. The external epidermal layer has many glandular cells like those we have described in the integuments. It is naturally very ciliated (pl. I, fig. 21, $e$ ). The connective tissue layer $(f)$ contains muscle fibers, denied by Hoffmann, Teuscher, confirmed by Hamann, some longitudinal, some circular. The longitudinal ones retract the papulae when they are irritated. The circular ones close the lumen of the organ if it bursts so the liquid of the body cavity is not lost. These muscle fibers are especially visible in tangential sections. The internal peritoneal layer $(p)$ is very ciliated. The cilia produce a spiral movement known by the old anatomists. Plasmodia or blood corpuscles inter into the papulae to go around and exit the opposite side.

The papula is surrounded by a circular lacuna (pl. I, fig. 20 and 22, l). It has been seen by all those who have worked with asteroids, Ludwig, Teuscher, Hamann. Hamann made the lacunar system an extension of the body wall (Schizocœlraum). He does not represent it as closed but continuous with a series of cavities. It is not so. This lacuna is perfectly closed. It does not have an epithelium of the schizocœl as Hamann suggested. The nuclei seen at its surface are those of undifferentiated cells located at this level. But it does not have the constitution of an epithelial covering. It is a simple separation of the connective tissue whose role is the following: when the papula is dilated, under the influx of internal liquid, it tends to close those cavity and then it acquires a great capacity. By this arrangement, the perforation of the wall is also as small as possible, corresponding to a sufficient respiratory surface.

The distribution of the papulae varies greatly according to species, but they are all of this type. In species with a thick skin (culcitids), the wall of the body has numerous irregular cavities (pl. VIII, fig. 18, br) that are always divided. These are diverticula of the body cavity going out to the papulae. In Luidia ciliaris, the papulae, instead of being simple as in cribellids, asterinids, etc., form a dense tuft of small caecae. This group is surrounded by the usual lacuna (pl. I, fig. 22).

I shall examine the functions of the papulae in regard to the haemal liquid.

\section{Ciliated spines}

The study of the papulae is connected to that of the ciliated spines. They are found only in the genera Luidia and Astropecten.

In Luidia ciliaris, the border of the arm is limited by a series of flat plates perpendicular to its direction. Between these are regular, very large spaces. These are marginal pieces having four spines. The lateral surface, bodering the spaces mentioned above, have very small articulated spines that form a continuous covering. When these spines are placed under the microscope, one sees that they have the form of a long round cylinder at the top (pl. I, fig 19), about $1 / 2 \mathrm{~mm}$ and covered with extremely stout and long cilia. In the center is a calcareous system, very delicate, determining the rigidity of the organ (fig. 19,r). The cilia are on an epithelium with elongated cells. They have an action so strong that a detached spine turns on itself with a great speed. 
The current produced by the action of all these cilia is directed from the upper surface towards the lower one. I do not confirm this because it is very difficult to determine the exact direction in a living animal. However, I have clearly seen small particles in suspension in water transported in this direction.

The papulae of luidiids are aligned regularly in transverse rows. Now, a ciliated space corresponds to each row. I think the ciliary movement functions to determine an active movement of water on these papulae. Without that, respiration would be very rudimentary. The paxillae covering the lower surface prevents an easy renewal of oxygenated water.

The ciliated spines also exist in Astropecten aurantiacus, platyacanthus and bispinosus, especially around the disk. But they are far from having the same importance as in Luidia ciliaris.

\section{Pedicellariae.}

These are small grasping organs that do not exist in all asteroids. Astropectinids, for example, lack them.

Perrier was the first to study them in great detail (43). He established a distinction between two principal forms: the pedicellariae that have two jaws and a basal piece (Asterias and close genera) and those that have two or three jaws, articulated directly on the integument (Asterias with two rows of tube feet).

Luidia ciliaris has two kinds of pedicdellaria: one tridacatyle described by Perrier; the others didacatyle that no one has yet reported. In the individuals from Roscoff, the first are easily seen. They are found in small numbers on the borders of the ambulacaral groove. In individuals from Banyuls, I have found only tridactyyles. But between the maraginal plates, on the border, with the ciliated spines are found pedicellaria with 2 jaws (pl. II, fig. 1). There is one at nearly every marginal interval. $5 / 4 \mathrm{~mm}$ in length, their finely toothed jaws meet over their entire height. The pedicellaria is articulated at its base on the calcareous body wall, a transverse muscle cause the closing of the jaws. The external ones open them. It is even in the same species that are found in the Ocean and the Mediterranean. This variation is thus simply individual.

Gymnasteria carinifera, a species close to Culcita and Pentaceros, gives an analogous example. I have studied two species of them preserve in alcohol, coming from the Red Sea (near Obock). Perrier described very unusual pedicellariae in this species, located on the lower border of the arms among the papulae. Nothing similar exists in my specimens: the arms have no pedicdllariae. But in the ambulacral groove, attached to the border plates, are numerous didactyle pedicllaiae (pl. I, fig.14). The figure is better than a long description. The toothed jaws rest on each other for part of their height. They are also joined at the base. A transverse muscle $(a)$ closes the jaws. External muscles $(b)$, attached to the piece that supports them, opens them. Finally, a strong bundle of connnective tissue fibers $(f)$ attaches the pedicellaria to the groove in which it is enclosed

Perrier also spoke of the spicules in the dermis. There are certainly none in my specimens of Gymnasterias carinifera. I consider all these difference as simply individualistic.

The pedicellariae of Asterina gibbosa, a very interesting species from many points of view, found in abundance on the shore of Roscoff and Port Vendre, has very special characters.

The lower or aboral surface is covered with scales on which are various spines, isolated or united in more or less numerous groups. Didactyle groups are very frequent. Are these pdicellariae? Perrier thought so. Now, the differences of pedicellariae and of a spine are the form, the musculature and the particular movements. These three characters are lacking in Asterina gibbosa. The groups with two spines have the same form, the same coloration as the others. The 
transverse muscle that connect them and that appears so characteristic to Perrier is found between all the spines, connecting them two by two. Finally, very often three or four spines of a group come together when they are stimulated. I readily recognize that the groups of two contract more strongly and more quickly than the others. This is especially seen in the specimens from the Mediterranean. But it is impossible to establish an absolute distinction between spines and pedicellariae that shows the best transition. Expressed in another way, I shall say that these are pedicellariae that are scarcely different from spines.

I think the preceding examples are sufficient to prove that, in some species, these organs vary according to the provenance of the individuals. This observation will have some importance when I consider their functions. If this fact is accepted (which still needs other examples, I do not consider it as shown), some species that have been established only by the different pedicellariae would have to be rejected,

Asterias glacialis is certainly the best species in terms of the pedicellariae that show the greatest degree of complexity.

As we know, from the works of Duvernoy, Herapath and Perrier, we can divide them into two groups: crossed pedicellaria (forciform of Herapath) and straight pedicellaria (forficiform of the same author). I shall add a $3^{\text {rd }}$ group, that of tridactyle pedicellaria.

The first, very small, in immense number, forming collars around spines have three pieces, two jaws and a basal piece described by Perrier. Each jaw has proximal part going to the basal piece (pl. 1, fig. 1).

The six muscles, described more or less accurately by Perrier Two (fig 1,b), that open the jaws are very reduced, inserting from one part on the basal piece, the other part on the external part of the jaws. Four close it, the first two entering the interior of the jaws and inserting on their calcareous cross bar of one part on the basal piece of the other part (fig. 1, $a$ ). The two latter form a double transverse bundle attached on the latter and on the proximal part of the jaws (fig. 1, $a^{\prime}$ ). This not all. At high magnification of the crossed pedicellariae of the living animal, one can see a white bifurcated peduncle that clasps the pedicellariae (fig. 1, f). This is what Perrier called the general motor muscle. This not a muscle, but a mass of very fine and very resistant connective tissue fibers. The bundles are divided into two branches that cross each to envelop the proximal part of each jaw. We see immediately its usefulness.

I have believed it necessary to give a figure of the crossed pedicellariae, that of Perrier being inaccurate from various points of view, especially regarding histology.

To study the histology of the pedicellariae, it is necessary to make sections. The most instructive preparation is the vertical section of a spine with its collar of crossed pedicellariae. A half of such a section is shown in fig. 2, pl. I.

The entire base of this collar is a flexible and mobile tissue formed of connective tissue fibers with a large nucleus mixed with muscle fibers, forming a maze that prevents description. Numerous undifferentiated cells are found mixed there. One recognizes elements with diverse colors stained with carmine. The peduncles of these pedicellariae, stained bright pink that contrasts greatly with the less deep color of the other elements, remain isolated to the base of the collar. Their fibers are dissociated and are lost in the very confused maze mixed with other fibers (fig. 2, f). One part of the collar goes up the length of the spine that serves as an axis for it. There are numerous muscle fibers $(m)$, which explains how it can be covered by the sheath that surrounds it. These muscles are inserted on the calcareous mass of the spine. Their other ends are lost in the tissue of the collar. 
Various muscles stained golden yellow are seen on the section of the pedicellariae $(p)$. All that is not calcareous is formed of connective tissue fibrils. All is covered with an external epithelium that goes between the jaws where it is interrupted here and there by calcareous asperities. The epithelium is identical to that I have described above. It is excessively glandular. One also sees many clear spaces, intercellular vacuoles.

Straight pedicellariae. - The straight pedicellariae are less numerous than the preceding, isolated or in small groups. Their size is sometimes considerable, up to $4 \mathrm{~mm}$.

They are formed of three hollow calcareous pieces, known for a long time, a basal and two jaws. The figure given by Perrier of straight pedicellariae of Asterias glacialis agrees little with what I have observed. It recalls rather Asterias rubens. In large pedicellariae of 2 or $3 \mathrm{~mm}$, the jaws do not articulate for their entire length as he shows, but only at their end that is widened and with teeth that mesh with their counterparts (pl. I, fig. 9). Sometimes, in some specimens, this toothed part is considerably widened and the jaw takes a discoidal form (pl. I, fig. 10). It then has a large size, 3 and $4 \mathrm{~mm}$.

Before reaching the form shown in fig. 9, the straight pedicellariae of young Ast. glacialis have the aspect that Perrier showed, and that is fixed in A. rubens.

The muscle apparatus of these organs has always been very badly described. It is necessary to study it in longitudinal sections that are not very easy to do, it is true, but that give very clear results (fig. 11, pl. I. There are six muscles that have only little or no resemblance with the muscles of crossed pedicellariae (fig. 11). Two small bundles that open the jaw (fig. 9 and 11, b) insert on the basal piece and on the external and lower part of each jaw. Four close it. Two of these are very large, entirely hidden in the calcareous pieces, going from the base of the basal piece where they are inserted up to the end of the jaw (fig. 11, $a$ ). The other two, much smaller, are inserted in a part on the basal piece and the other part on the lower and internal part of each jaw (fig. 9 and 11, $a^{\prime}$ ). Perrier has described and figured (43) a general motor muscle attached to the basal piece and recalling that of crossed pedicellariae. This bundle does not exist. One can be assured of this either in living animals where it is easy to see with the magnifying glass or in sections.

The straight pedicellaria is enveloped in a connective tissue sheath covered with the external epithelium. The connective tissue is formed of numerous fibers and undifferentiated cells, isolated or in a mass (pl. I, fig. 12, f). The epithelium contains the same glandular cells that we have already seen.

I end by the study of the tridacatyl pedicellariae that have not been reported by any author. They are very rare and are not found in every individual. They are found on the arms, mixed with straight pedicellaria of the same size. I have observed them at Roscoff and at Banyuls. The specimens with them had only two or three on each arm. Figs. 7 and 8, pl. 1, show two that are very different. On is probably only a young form. They are composed of 3 jaws, articulated on a single basal piece. The musculature is the same as that of the straight pedicellariae. They are of interest because they reproduce in the most perfected type of asteroid the form of pedicellariae of Luidia, which is the lowest type.

Individual variations. - Asterias glacialis of different origins show considerable differences in their pedicellariae. These are variations comparable to those that I have shown in Luidia ciliaris and Gymnasteria cariniferu. Thus, at Roscoff, the species found at Réc'hier Doun, a rocky shore beaten by waves, living in the midst of a very rich fauna composed exclusively of attached species, ascians, bryozoans, ciripedes, bivalves etc., having only dark colors. Their pediceellariae are not numerous and of very small size. The characters that I have figured of the straight pedicellariae are not clear. They are mixed with those of Ast. rubens, The same 
observations for a dwarf variety of Ast. glacialis of dark green color, found at Banyuls under rocks constantly beaten by the waves and living in the midst of a fauna of fixed species.

To the contrary, Ast. glacialis that we collected near Astan (northeast of Roscoff) and found in the midst of a fauna extremely rich in annelids, crustaceans, bryozoans and ascidians has clear colors, pink or white and a considerable development of pedicellariae, both straight and crossed. The collars that are found around the spines are nearly always present. The very numerous and very large (1 to $4 \mathrm{~mm}$ ) straight pedicellariae meet exactly the preceding descriptions (pl. I, fig. 9 and 10). The same observations for the large Ast. glacialis collected at Banyuls. The straight pedicellariae have very great variation in form even on the same individual.

Development. - Development of pedicellariae can be studied either in young or even in adults where there are always some in process of development or on regenerating arms.

The two kinds of pedicellariae differ only at a very advanced stage. They begin by a slight protrusion of the integument. The mamelon that forms is a low pedicle, then becomes bilobed at its free end (pl. I, fig. 3). In each of the two lobes thus formed that always growing appear some parallel calcareous rods that are grouped. These are the rudiments of the two jaws (pl. I, fig. 4. When they are clearly formed, the basal piece appears. It grows rapidly. It has a triangular form (pl. I, fig. 5). If it is a straight pedicellaria, the pieces expand and grow considerably in a way to form a completely hollow apparatus. One recognizes in the three rudiments the constituent parts of the straight pedicellaria.

If it is crossed pedicellaria, development continues. The elongate, rough jaws form on their surface. The lower part that is on the basal piece elongates into a kind of rounded handle. One of the extensions moves to the right, the other to the left from the basal piece. The muscles begin to form; the fibrous peduncle also appears. The characteristics of the crossed pedicellaria are easily recognized (pl. I, fig 6).

This development shows how unwarranted is the opinion of Perrier who said, in his work on the pedicellariae: " “...The structure so particular of these organs (crossed pedicellariae) alone is sufficient to reject any idea of a relation or abortion tending to unite them to straight pedicellariae..." (43, page 213$)$.

We can make an interesting conclusion from this. We have seen that the asteroids one can call lower, those with two rows of tube feet, have didactyle pedicdllariae, without a trace of the basal piece (pl. I, fig. 15 and pl. II, fig. 1). The pedicellariaae so perfected in Ast. glacialis pass by this phase. There is better: the tridactyle pedicellariae of Luidia is also found in Ast. glacialis, always with the basal piece in addition (pl. I, fig. 7 and 8). Finally, the crossed pedicellariae is a perfectioning of the straight pedicellaria. We shall see in its physiologoy that it is much more useful to the animal. Following the expression of Hœckel, so often used today, the ontogeny of the pedicellaria agrees with its phylogeny.

Physiology of the pedicellariae and the dermal glands. — We still know nothing with certainty of the functions of the pedicellariae. The opinions are based on incorrect observations or are not general.

It is without doubt they are grasping organs. But what do they grasp? Perrier gave no hypothesis on their functions. Romanes and Ewart (54) gave an active role of locomotion to the pedicellariae of urchins. It is sufficient to observe a living urchin to be convinced that they move only with the spines or tube feet. And that the pedicellariae have nothing to do with it. This explanation is not applicable to stars that move on a side nearly lacking in pedicellariae. The cited authors explain their preence as being inherited organs, vestiges without usefulness to the animal. It is sufficient to have studied them, even superficially, to see how this opinion is absurd. 
Agassiz gave the pedicellariae of urchins the role of moving fecal material on the lateral sides of the animal, from where they would be easily swept off by sea water. In any case, this is inapplicable to stars.

Other authors, based on the abundance of pedicellariae near the buccal membrane gave them the role of gasping food. This is inapplicable to asteroids that feed on large urchins, crabs, debris or fish, generally immobile. In any case, grasping it by means of the tube feet/

I am absolutely convinced that the pedicellariae of asteroids have a purely and exclusively role of defense. I base this opinion on numerous observations made on living animals at Banyuls and Roscoff. I take the example of Ast. glacialis. This animal is entirely lacking in parasites or foreign bodies fixed on its appendages. There are neither diatoms nor ciliates that are so abundant in ophiuroids. It is however vulnerable because a worm could penetrate the opening of a papula and perforate the thin membrane. I think the pedicellariae serve to defend it. In fact, of one touches it, even very slightly, a part of the integument or a collar of pedicellariae, the surrounding papulae contract in order to escape from the irritating cause. So if one touches the collar of crossed pedicellariae on one side only, only the papulae on this side contract.

When puts a small annelid or nematode on the integument, the phenomena that occur are most remarkable. When the animal touches a collar of pedicellariae, the surrounding papulae rapidly contract and remain in this state as long as the worm is active. The surrounding spines, in spite of their apparently immobility, very clearly lean towards it in order to help the pedicellariae that have captured it. Their collar of pedicellariae leans as much as possible to try to seize and immobilize the struggling animal. At the same time, the abundant glandular cells on the appendages of the body wall release their products. The animal becomes enveloped in mucus, overwhelmed with vesicles that perhaps are venomous. Its death is not slow to occur.

No one says the asteroid cannot take advantage of this. I have seen living individuals capture annelids of 5 to $6 \mathrm{~mm}$ that crawl on their surface. The pedicellariae have held them for some time, a day and more, then released them. Asterias glacialis captures living bodies of small size that irritate its integumentary surface, keeps then until their death and even beyond whatever they are, always very different from the usual food. I have found often, in separating pedicellariae under a strong magnifying glass, small nematodes that I had not seen at first and that probably had been killed by the glandular cells.

The nematocysts of coelenterates are also defensive organs, very feared by all the animals that live with them. If one puts in an aquarium an actinian with its tentacles extended and an Asterias glacialis from Astan, for example, and observes their behavior, one sees that a shrimp flees both with the same rapidity when it happens to touch with its antennae the atinian or the asteroid. Each time one wounds an asteroid, either by irritating its external surface or cutting it, it secretes a considerable quantity of mucus that can play a defensive role there. When one irritates a portion of the integument lacking pedicellariae located, for example, between two collars, one sees these two masses bend to the contact to seize the apparent enemy that attacked it.

All these observations are applicable to the straight pedicellariae. These are supported by a thick, more or less long peduncle. If one touches the base with a fine needle, on any side, one sees the pedicelariae incline from this side, with more or less activity, to seize the enemy that menaces it. When it has reached it, it closes its jaws abruptly, having opened them before. If it does not seize anything, it reopens them a little after and resumes its original position if the stimulus has stopped. The straight pedicellaria can describe a nearly a half circle in the vertical or horizontal plane. 
The relation I have determined between the abundance of pedicellariae and the richness of the fauna supports again my opinion. One can again remark that the species with pedicellariae in the ambulacral groove do not have commensals, while Luidia ciliaris, Echinaster sepositus, various Astropecten have nearly always one or several annelids (Ophiodromus flexuosus, Archolë astericola) in the ambulacral groove to the movements of which the very delicate organs found there have become accustomed (Banyuls).

The fibrous bundle that supports the base of the crossed pedicellariae functions to prevent a too great separation of the jaws (pl. I, fig. 1,f), but I believe it mostly unites these organs. It is twisted on itself to provide more resistance. In fact, when they grasp a foreign animals, the pedicellariae have sometimes to support a considerable pull. If this becomes too strong, the pedicellaria is lost. It is separated from the connective tissue peduncle that remains attached to the asteroid. It is at the point of union of the jaws and the peduncle that the effort is the greatest. We then understand that the peduncle increases resistance at this point. The straight pedicellariae, having a wide base and being much more robust, are naturally lacking in fibrous bundles.

We have seen that the only vulnerable points are the tube feet and especially the papulae. Also the pedicellariae are in great abundance in both of these regions. In all the asteroids that possess pedicellariae, these are found either in the midst of papular pores or on the borders of the ambulacral groove (Culcita, Pentaceros, Archaster, etc.).

But there are many asteroids that lack pedicellariae. How do they defend themselves?

Echinaster sepositus, that has a soft and vulnerable skin, has an immense number of venomous glands that, at the least shock, releases their contents. They secrete vesicles completely like the muriform cells of Asterias glacialis. These glands have a physiological role identical to those of the pedicellariae.

Astropecten aurantiacus, that has numerous papulae, has neither glands nor pedicellariae. But we know that the papulae are located between the paxillae, calcareous pieces with a circle of radiating spines at the top, forming a coarse umbrella. In living, healthy animals, the papulae swell and pass between the intervals between the paxillae. If one touches, even slightly, the top of a papula, these first contract and then the paxillae come together, their radiating spines are lowered in interlocking with each other in a way to form a nearly impenetrable roof above the injured point. Moreover, Astropecten has numerous muriform and mucous cells in its integument (pl. I, fig. 18). When it is irritated, it also secretes a large amount of mucus. The paxillae play here the same role as the pedicellariae of Asterias and the glands of Echinaster.

Each asteroid has very probably its means of defense in relation to its particular enemies. To prove this, it is necessary to observe living animals in the natural environment, which is often difficult.

A last argument: in Holothuria impatiens, one finds very numerous filaments, the tubes of Cuvier that are expelled from the body. Jourdan ${ }^{1}$, who has studied them, considers them as defensive organs: "It is easy to see, he says, how these large sticky filaments would inconvenience the animals that attack them." The internal epithelium of these tubes is formed of large muriform cells that we have described. In their young form, these cells have likewise a protoplasm in a polygonal system. It is interesting to find again at such a distance exactly the same venomous cells.

I speak only as a reminder of the spines that border the ambulacral groove. When the tube feet are irritated, these contract and the spines on the groove are lowered to close it completely. It is the same for those that surround the eyespot and the terminal tube foot of the arm. These spines form a kind of spiny eyelid whose contraction is very rapid.

\footnotetext{
${ }^{1}$ Jourdan, Ann. Mus. d'Hist. nat. de Marseille, v. I, 1883.
} 
Luidia ciliaris is a beautiful, very active species that lives on rocky bottoms, drift algae etc. One often finds it in the process of devouring the bait on the ropes used to fish for dogfish (Roscoff). When one grasps it strongly, that portion remains between the fingers and it rapidly escapes. Thanks to a contraction of the peritoneal muscle fibers, the wound is closed immediately by the close application of the lower surface to the upper surface. It is a special defensive method, analogous to that of the crab that loses its claw in the hands of those that have seized it (Fredericq).

Nearly all asteroids have this particular defensive behavior that is autotomy. If an arm is attacked and the ordinary means of defense of useless, the part is separated from the rest of the individual and it can then freely flee. In Ast. glacialis, the rupture is nearly always at the edge of the disk. In other species, Astropecten, Luidia, Echinaster, Asterina it is in the interval between two arm ambulacra. The arms that regrow often have a different color (Ast. glacialis). Generally, there remains no trace of the separation so there is no difference in size. The various organs reform very rapidly. I have seen in adult Echinaster sepositus, one arm in the process of regeneration measuring $3 \mathrm{~mm}$. The eye, the terminal tube foot and the tube feet are perfectly formed. In regeneration, a scar forms of undifferentiated cells and blood clots. Then all the lost organs grow and keep their proper structure.

\section{Digestive tract.}

Asteroids have a voluminous digestive apparatus filling a large part of the disk and the arms. Its general form has been known for a long time (Tiedemann, Müller and Troschel). As a general rule, it is formed of a retracted esophagus opening into a vast stomach with very folded walls. From the lower part of this extend ten glandular, very folded caeca that go into the arms. These are the radial caeca. Still lower, near the anal opening, are some glands that I call stomach caeca. The anus is lacking in Luidia and Astropecten. There are no stomach caeca in Luidia, as has been stated by Mùller and Troschel. When an anus is present, it is asymmetrical and in a very constant location. When the star is observed by the lower or aboral surface, the madreporite is placed before, the anus is always in the following interradius, to the right of the plate (pl. V, fig 9, 10 and 11, an). Lóven has shown it was the same in the very young regular urchin. But in them, the anus is deplaced little by little to the right to make it opposite the ambulacrum that follows the interradius that it left. This relationship has a great importance in regards to fixing the anteroposterior plane of the asteroid.

Asterias glacialis. - The digestive tract forms from a horizontal part that invaginates at the center to form the buccal opening. Leaving the mouth (pl. IV, fig. 1 and 2), the digestive tract increases in size. Its walls are greatly folded. Finally, after having produced the radial caeca, the sac is against the lower and internal wall of the body wall where it receives the stomach caeca. A very clear, very glandular zone is located in this lower part of the digestive tract, having numerous small folds forming a kind of smooth surface that is extended into the lower part of the radial caecum. The esophageal part is smooth, more brightly colored and appears also more glandular than the very folded portion that follows it and separates it from the stomach.

This general type can be applied to all asteroids. In all the beginning and end of the stomach are slightly more glandular than the intermediate part. But, in no type is it as clear as in the Echinasteridae. The lower portion of the stomach, according to the state of fullness of its cells, is 
colored bright red or orange. The upper portion or esophageal has an usual development (pl. II, fig. 14). When one opens an Echinaster sepositus by its lower surface, after raising most of the stomach, one sees ten pouches of a reddish brown, with extremely folded walls, that form a crown around the esophagus. They are about 4 or $5 \mathrm{~mm}$. They are held by strong mesenteric cords that connect the digestive tract to the ambulacral ossicles. Their internal cavity is nearly hidden by their numerous folds. Because the esophagus has the same red color, one can consider them as glands that are added to it. Cribella oculata also has them, but less brightly colored. It is probable that Culcita, Pentaceros and Gymnasteria have very voluminous ones, but alcohol deforms the digestive tract so much that one cannot give an exact description of it.

Radial caeca. - Radial caeca ae present in all the asteroids I have studied. Morphologically, they are diveticula of the stomach that are extended into the free part of the arms. They appear only very late. In a young Astropecten squamatus whose major radius (measured from the center of the mouth to the end of the arms) is $12 \mathrm{~mm}$ (one fourth of the adult size), they have a length of $4 \mathrm{~mm}$ (pl. III, fig. 5). It is a simple tubular elongation of the stomach, with accentuated folds and having the same histology.

But they are very differentiated in the adult. A very flat, wide sac (pl. II, fig. 20, p) with lateral pouches perpendicular to its direction, and which alternate regularly. These pouches in turn are folded laterally a number of times to considerably increase the surface. Only these latter folds are colored black or brown. The rest keep a whitish color identical to that of the stomach. The median, which is the direct extension of it, is enlarged at its base and opens by a very large opening into the digestive tract. Sometimes these caeca seem to originate by pairs on the same extension (Asterias, Mùller and Troschel). In others, they are very separated. These are unimportant details. They are sometimes very short. In Astropecten platyacanthus, spinulosus and squamatus, where they are scarcely a third of the arm. It is the same in Palmipes, this nice and singiular species that is regularly pentagonal. As the arm cavity is nearly nothing, the radial caeca remain in the disk but exist never the less (pl. II, fig. 13, r). They are 4 to $5 \mathrm{~mm}$ in an individual with $\mathrm{R}=21 \mathrm{~m}$. The structure that with just described in the families Asteridæ and Astropectinidæ. The families of Echinasteridæ (Echinaster, Cribella) and Asterinidæ (Asterina, Palmipes, Solaster) have a special improvement: the median sac is extended considerably and forms a large reservoir that, in the natural position of the animal, is located below a radial caecum. This reservoir extends nearly half or three fourths of the caecum. It is marked with regularly spaced oblique folds (pl. II, fig. 11, 13, 18). It has a large opening into the stomach, of which it is only a continuation (pl. II, fig. 15, $s$ ).

Stomach caeca. - No part has more variation of form. It has been given the names of Blinddarmchen (Tiedemann) and interradial caeca (Mùller and Troschel, which implies an alternation with the radial caeca. I reject this name, because it is in no way true. These caeca have the most diverse and locations and have no morphological relation to the interradius. Carl Vogt and Yung called them rectal caeca in Astropecten aurantiacus, as representing the rectum that is lacking in this species. It is only necessary to remark that these caeca exist also in the asteroids with an anus to reject this opinion.

They are simple diverticula of the stomach, analogous to the radial caeca, having the same histology. One can be convinced by the study of its development. In very young Astropecten aurantiacus $(\mathrm{R}=82 \mathrm{~mm})$, we see them appear as simple tubular extensions of the stomach (pl. III, fig. 4). These extensions, first separate, are then united, then are greatly folded to their interior. They slowly attain their adult size.

We know they are lacking in Luidia. The interior part of the stomach resembles greatly the same part in ophiuroids. They are closely applied to the wall of the body by numerous mesenteric 
cords. In all astropectinids I have studied, the very small stomach caeca form a mass separated into two lobes connected by a mesenteric cord attached to the test. The two lobes are more or less equal and regular in Astropecten aurantiaacus; these are the Blinddarm of Tiedemann (pl. III, fig. 6. They are very small but equal in Astr. spinulosus and squamatus (pl. III, fig. 7). In Astr. hystrix, the two lobes are very elongate and are free in the body cavity (pl. III, fig. 9). Finally, in Astropecten platyacanthus, each lobe has some small secondary tubes that ramify again at their end (pl. III, fig. 8).

If we carefully cut the mesenteric cord and its connections to the test, we see in the area where the anus should be, calcareous plates arranged in concentric rows that gradually thin to limit a small central space (pl. III, fig. 7 and 9,a), so that one could believe in an anal opening. Effectively, the body wall is reduced at this point to a very thin layer but it is not perforated. We know, according to Lóven, that the anus is produced from inside out. The body wall thins more and more until perforation of the body wall is complete (Ast. glacialis). Besides Luidia ciliaris that has a perfectly smooth body wall without any trace of thinning, Astropecten is stopped at a later phase but the opening is not yet functional. Finally, in Archaster, so close to Astropecten that it is nearly impossible to distinguish them, there is a very small but perfectly formed anus

The stomach caeca are likewise formed of two lobes in Brisinga coronata (Ludwig, 33).

In the family Culcitidæ, Mùller and Troschel have shown that there are ten stomach caeca. It has five interradial tubes that soon divide into two branches going into two contiguous arms. I have found this form in Pentacerous turritus and Gymnasteria carinifera.

In Asterina gibbosa, they are very reduced and divided into five very deep lobes (pl. II, fig 11, c, and 12). Palmipes has five long, very thin tubes (pl. II, fig. 13, c).

In Echinaster sepositus and Cribella oculata, the stomach caeca are very irregular. They form a very large pouch, brightly colored, that follows all the bends of the interior wall. There are generally five lobes, each is bifurcated to go into two contiguous arms (pl. II, fig. 15 and 17). If we opens one of these sacs, we see that they are not simply folded at their interior, but well covered with very large villi, visible with a magnifying glass (pl. II, fig 16). In all these types, this glandular apparatus opens into the stomach by a large opening that can be closed by a sphincter. At the opposite end, it is extended to form a short rectum of several millimeters with a very strong muscular wall. The feces, to be released (if they do, which is doubtful) are forced to cross the gland.

In Asterias glacialis and rubens, the glands are very irregular and have much individual variation. They are formed of a variable number of elongated tubes, a little ramified, divided into two groups by a mesenteric cord and that converge towards the same point. According to the state of their cells, they are greenish black or gray. I once saw one of them purple like the caeca of Echinaster. When we prick them with a needle, we see them slowly contract. They have, in fact, a strong muscular layer. In the interior, they are extremely folded. In young Asterias (pl. II, fig. 19), there are only three very small caeca, and the gland becomes convoluted until it reaches the state represented in fig. 19. These stomach caeca are not inserted directly on the digestive tract. The stomach is extended into a short rectum and it is on the flanks of the rectum that opens the small pouch with thick walls formed by their reunion. Their contents, in spite of this apparently unfavorable arrangement, can flow back into the stomach when the rectum is closed at the end by contraction of is walls. This can be proven by injections into the ends of these tubes. Most of the colored liquid passes into the stomach without any escaping by the anus.

Histology. - The digestive tract is formed of four layers: an internal, the glandular epithelium filled with a thick cuticle; a connective tissue layer, a muscular and an external zone 
formed by the peritoneal epithelium. The muscular layer is very thick in the horizontal portion of the esophagus where it is formed of radiating fibers (pl. IV, fig. 16, $m$ ). This explains how the mouth can be closed or opened wide. It is formed of circular fibers in the stomach caeca (pl. II, fig. $21, m)$. Finally, it is very thin in the stomach and absolutely lacking in the radial caeca. The connective tissue layer, formed of fibrils and fundamental tissue, varies in thickness with location, like the muscular layer. It is very thin in the radial caeca (pl. II, fig. 26). In all the folds or villi, it sends a supporting glandular epithelium (pl. II, fig. 21). In Culcitidae and Ophidiaster Chinensis, there is a large number of spicules in the connective tissue layer, as well as in the mesenteric cords. These spicules have the most diverse forms (pl. III, fig. 10), small rods, pitted plates, but never geometrically defined.

There are two kinds of glandular cells. One is mucoid and very expanded. The other is granulose, which secretes the digestive enzymes and which are much more important. To study them successfully, it is necessary to keep them in $1 \%$ osmic acid for 24 hours and cut them into small pieces after a more or less prolonged period in distilled water. (Procedure of Ranvier.) The mucoid cells (pl. II, fig 22, q, fig. 21) are calycinal. They are composed of a great enlargement in the form of a cup, supported by a pedicle containing the nucleus. Sometimes we see a very clear reticulum in the cup (pl. III, fig 3). These cells are ciliated and have two or three ciliated, but without a cuticle. They are found everywhere but especially in the esophageal pouches of Echinaster. They secrete a transparent mucus that envelops the prey of the asteroids but I do not believe they have any direct action in digestion. The cells in the form of a bottle described by Hamann do not exist. I have never found them in my numerous sections while I can confirm the presence of the cells I describe.

The granular cells are very different. They are very long, 70 to $180 \mu$. They contain a reticular protoplasm and an ovoid nucleus and a nucleolus. They base is very small and is inserted in the underlying connective tissue layer. Small refringent granules form in the protoplasmic reticulum (pl. II, fig. 23 and 25). When they reach a certain size, they fall into the spaces until the cell is filled. I cannot explain how these granules leave the cell because these are covered with a cuticular layer with one or two cilia (pl. III, fig. 3,c). They exit in some fashion, leaving a reticular that begins a new development. In the living state, the granules are pale yellow, rarely slightly purple or brown. I have assured myself that ophiuroids have identical cells with brown granules in all the stomach covering. According to the studies of Jourdan, the digestive element of holothuroids is similar to that we just described. Finally, in actinians, according to the works of the Hertwig brothers ${ }^{2}$, the esophageal canal (Schlundrohr), in addition to the mucoid and epithelial cells, have a large number of digestive cells with large granules that appear identical to those of asteroids, with the same mode of secretion.

In Echinaster and Cribella, the digestive granules of the stomach have a much larger size than in the preceding descriptioins (fig. 24, 25, 26), which gives the cell a singular aspect. It is formed of a stacking of small spheroids that do not touch, being separated by the protoplasmic reticulum that has formed them. This is nothing other than a simple variation. The microscopic characters remain identical.

One will doubtlessly find some resemblance between the digestive cells of cribellids and the muriform cells of the external epithelium (compare the preceding figures with fig. 12, pl. I, $m$ ). They have a similar form, but the parallel we can establish stops there. In fact, the two kinds of granules respond in a manner completely distinct with the various reagents. Thus the digestive

${ }^{2}$ O. and R. Hertwig, Die Actinien, Jenn, 1879. 
granules are refractory to carmine that stains the others pink. They do not resist at all picric acid, which leaves the second intact.

All my figures represent active cells, full of granules. But the aspect is completely different when the cells are empty. One sees only large protoplasmic filaments that have the most diverse forms and without any trace of granules. Apart from this indifferent state, the granulose cells are more or less widespread in large number on the surface of the digestive tract. They are more numerous at the beginning (esophageal zone) and at the end (stomach zone) (pl. II, fig. 22, 23, 25). In the intermediary part, they are mixed with indifferent cells. The stomach caeca (pl. III, fig. 2) and the radial caeca (pl. III, fig 1) have an epithelium formed entirely of digestive cells. The reservoir of the radial caecum (pl. II, fig 26) is less active. We have already seen that the epithelium is a little special in Echinasteridæ. The esophageal pouches (pl. II, fig. 24) contain many cells with large granules mixed with mucoid cells.

Finally, except in the stomach caeca, we find everywhere mucoid cells, rare, it is true.

A fibrous layer, which should be considered as nervous, runs between the bases of the cells. I have found it decreasing in size the entire length of the digestigve tract from the esophagus to the anus. It is extended, likewise very reduced, in the reservoir of the radial caecum. Finally, in Astropecten aurantiacus, I have found it with indisputable clarity in the stomach caeca. Hamann has recognized a nervous layer in the esophagus, but the figure he gives of it is not very accurate. He says that he was not able to follow it further. I shall talk of it when I consider the nervous system, where I shall give the proof of its nervous nature, this question being very discussed at this time.

Physiology. - All those who have observed asteroids at the sea shore know their singular mode of capturing food. When a star has found a prey, it evaginates its stomach that is applied to it to completely envelop it in its folds. Indeed, the food particles are detached little by little by the action of the digestive enzymes, but they are ingested into the anterior portion of the digestive tract. There the true digestion of the food occurs transforming it into soluble substances. As soon as we disturb the asteroid, it abandons its meal and withdraws its stomach into the interior of the body. To evert the stomach, it contracts the peritoneal muscles. The pressure of the liquid in the body cavity then everts the digestive tract. To retract it, the muscles of the mesenteric cords contract and pull it into the interior.

At Banyuls, we see Asterias glacialis in aquaria attack large urchins and devour all the nutritional parts on the test. At Rec'hier Doun (Roscoff), I have found in a small tide pool at low tide an asteroid of this species in process of eating a very large Portunus puber that had just molted. In this case the asteroids immbolize their prey with their tube feet. Their favorites are mollusks, especially lamellibranches. Although these can bring their valves close together, the asteroid holds them closely, secrete a soft mucus with special venomous properties, so that the mollusk soon gives up and opens its valves without being able to close them. The stomach evaginates and goes into the opening and soon has devoured everything. One can easily repeat this observation by placing in the same aquarium Asterina gibbosa and scallops or mussels. Asterina gibbosa even manages to devour extraoraly gastropods such as the periwinkle (Littorina littorea). When the prey are small, this species swallows them completely or in part and digests them interiorly (arms of ophiuroids, phascolosomids).

Asterina rubens, so common on some beaches, ravages banks of oysters or mussels. Oyster gatherers say that at some times they have destroyed entire banks at Cancale, Oléron, Arcachon, etc. de Montaugé cites banks of ousters at Tremblade, Portugal, devastated by the stars. ${ }^{3}$ In the

\footnotetext{
${ }^{3}$ De Montaugé, Les ennemis des huitres, pag. 16.
} 
river of Auray is a natural bank of 10 to $12 \mathrm{~km}$ without interruption. Asteroids have been taken by the fishermen who clean their nets near a bank near the middle of Ours river. This bank is currently devastated. The only recourse of the oyster gatherers is to dredge the bottom of the attacked areas and then to take the stars onto land where they can serve to improve the clayey soil. It is usual for some persons to impale the stars with a pointed stick like one does for slugs and throw them onto the beach. It appears to me completely insufficient. These animals have an extraordinary vitality. One other preventative method, asteroids not moving greatly, is to have the fishermen not to throw the stars from the nets into areas where they have not yet appeared.

All Astropecten and Luidia that I have studied swallow preferentially the mollusks that nourish them, while one rarely finds other species in the digestive tract. I have found around twenty Venus orate, all empty and digested, in the stomach of an adult Astropecten aurantiacus. It is useful to remark that the shell are never broken (which proves there is not the least trace of mastication) and that the most delicate calcareous details are perfectly preserved. Two Luidia cililaris collected at Roscoff the summer of 86 were caught on the fishing lines for dogfish $(S$ yllium canicuda) in the process of devouring the fish used as bait. Finally, I have found in the stomach of various Astropecten debris of crustaceans, cephalopods and fish scales. We see that if the asteroids are carnivorous, they voluntarily consume all sorts of food.

The food never goes into the radial caeca nor into the stomach caeca. Their content is these is moved naturally into the digestive tract when it is needed. Muscular contraction of the stomach caeca greatly aids the movement of secreted products. When starved, the radial caeca are empty or filled with little matter, in which one easily recognizes digestive granules, either mixed together and having the appearance of large greasy drops or still isolated.

What is the role of the anus? I have seen only one time an Asterina gibbosa and an Echinaster sepositus expel some excrement by the anus. We know the anus is very muscular; the bodies are projected abruptly far from the asteroid. But the use of the anus must be singularly restrained. I believe that works only when the excrement accidentally goes into the stomach caeca. The non-digested bodies are most often expelled by the mouth, as occurs necessarily in Astropectinidae and the ophiuroids.

We agree generally to attribute to the stomach caeca an excretory function. Their position near the anus seems to confirm the point of view. Milne-Edwards says that uric acid is found there. ${ }^{4}$ In this hypothesis, how can the absence of these important organs be lacking in Luidia? They are present in Astropecten where there is no anus and where their excretory product would have to cross the entire digestive tract.

They have the same histology, the same coloration as the very glandular parts of the digestive canal. Finally, I have sought many times to detect the presence of uric acid by the classic procedure and I have always had negative results. True renal organs such as the bodies of Bojanus of acephalids and mogulids give me obviously the colorof murexide.

We shall see, in regard to the haemal fluid, how excretion occurs.

Nervous system.

The nervous system of asteroids has been and still is the object of serious discussion. The uncertainty is not only about the constitutive elements but its place: that which is nervous for some is connective tissue or an epithelium for others. We see how the opinions differ.

\footnotetext{
${ }^{4}$ Milne-Edwards, Leçons de physiologie, volume 5, p. 324.
} 
Before beginning the history of the question, I believe it is better to describe the results of my research. This will make it easier to discuss and report the various opinions.

When one examines the upper or oral surface of an asteroid, with its tube feet removed, one sees at the border of the pentagon indicated by the calcareous pieces of the disk, a slight elevation of the buccal membrane that is extended into the five arms to the base of the ambulacral groove where it ends at the eye and median tentacle. If one makes vertical and horizontal sections of the peristome or the arms (pl. IV, fig. 6, 7 and 16, n), one sees below them this thickening, a wide vessel or sinus ( $s$, fig. $7 ; r$, fig. 16) that, in general is separated into two by a more or less thick septum. Still below it, separated from this sinus either by the vertebral muscles (fig 7, $x$ ), when the section is by an ambulacral ossicle, or by a connective tissue lamella, when it passes between two consecutive ambulacral ossicles (pl. VIII, fig. 10), a second vessel that is the radial canal $(a$ or $b)$.

It is in this upper thickening $(n)$ that is found the nervous system, running between the bases of the epithelial cells. A thin connective tissue layer covered by an epithelium separates it from the underlying hemal sinus (pl. III, fig.11, s). This epithelium also covers the vertical septum that contains the most diverse formations, as we shall see in regard to the circulatory system.

Dissection and the study of living animals cannot tell us any longer. It is necessary to have recourse to various reagents. The most precious is osmic acid at $1 \mathrm{p}$. 010 , which is used first along and then compared with preparations in carmine in osmic acid. When the coloration is as strong as possible ( $24 \mathrm{~h}$ and more), one places it in distilled water for 24 and $48 \mathrm{~h}$, to dissociate the elements. We disintegrate it in glycerin. Very thin sections stained with picrocarmine or carmine in boric acid also give good results. In the discussion that follows, I felt constrained to verify some facts reported by preceding authors, especially Hamann. But as Hamann has nearly always studied extremely young individuals, some millimeters in diameter, and only one species, it is not useful to generalize the discoveries he has made to adults. Moreover, they have been contradicted or interpreted in a different fashion by more recent authors, Perrier among others (50), which makes it necessary to make a second confirmation. These studies are very delicate and the controversies fierce enough to make a new finding superfluous.

The nerve ring and the radial cords have exactly the same constitution. They are formed of an epithelium with extremely elongated filamentous cells, between which are the nervous elements (pl. III, fig. 11). The lower part of the cellular epithelium is applied on the underlying connective tissue $(f)$. The upper part, a little enlarged, is flattened to support a thick cuticle, with one or two very short and not very active cilia. Whole cells measure $1.10 \mu$. The nuceli are located in the upper part, all at nearly the same height. They are large, oval or spherical, nuclolated, most often stuck together in protruding onto the cellular filament and surrounded by a small amount of protoplasm (pl. III, fig. 31,b). In the enlarged part of the cell are some protoplasmic granules. In Astropeten aurantiacus, the nerve cord is yellow (this is the orange vessel of Tiedemann, orange farbene Gefäss). This is due to irregular grains of yellowish pigment located in the cells I just described (pl. III, fig. 13, $a, j$ ). The cuticle is $4 \mu$ thick. It is formed of flat juxtaposed cells.

Between the cellular filaments and at about a height of $120 \mu$ is the nervous substance, fibers and cells. The fibrils are longitudinal in the radial cord, circular in the nerve ring. These are extremely thin fibrils whose structure cannot be perceived at even the highest magnification (1400 times). It is a mass of granulose substance, with a fibrous structure. It is refractory to carmine, colored gray in osmic acid. The fibrils are not stiff and parallel, but instead continuously anastomosing in a way to form a coarse fibrous plexus (pl. III, fig. 12, $n$ ). In transverse sections, they give the appearance of fine dots that with the hardest pencil one cannot exactly reproduce the 
appearance. Sometimes where they are found, they have exactly this description that makes them very easy to recognize. They are always parallel to each other. Never have I seen in my numerous sections or separations the crossed bundles of which Hamann speaks.

The nerve cells are very few. One sees them isolated in the midst of the fibrils and irregularly dispersed. It is in the radial cord and nerve ring that one finds them most frequently. They are everywhere where there are fibrils. They are fusiform (pl. III, fig. 12) with a large round nucleus, nucleolated, occupying exactly the center of the spindle. It is impossible to see if the fibrils depend on these bipolar cells. They are simply intercalated between the fibrils. They are the only nerve cells that exist. We see that they are not very important. All these multipolar cells that have been described (Wilson, Lange, Perrier, Carl Vogt and Yung) are cells of the connective tissue or of epithelial cells, and have no relation with those that are going to define.

The radial cord is not clearly delineated as claimed by Teuscher, Wilson, Carl Vogt and Yung, but it is continuous laterally with the external epithelium of the tube foot (pl. VI, fig. 8 and pl IV, fig. 6). In the interambulacral spaces, it spreads out in decreasing thickness. Hoffmann, Lange, Ludwig and Hamann have certainly seen this continuation. The epithelium hardly changes in shape. The nerve layer decrease in thickness and is found as always between the bases of the cells. In the tube foot, the fibrils are always circular. I have never seen longitudinal ones (Hamann). At the sucker (pl. III, fig. 22), the thickness of the fibrous zone increases slightly, as well as the height of the cells. The epithelial cells ae long, filamentous, with a nucleolated nucleus located at different heights. They have a thick cuticle with very strong cilia. One rarely finds glandular cells like those of the external epithelium. Jourdan has given a very erroneous description of the epithelium of the sucker of asteroids and he does not speak of the nerve layer.

At the end of the arm, the nerve strand (pl. II, fig. 14, 15 and 16) has ocular cups and covers the terminal tentacle. I shall reserve the description to the chapter on the sense organs.

The peribuccal nerve ring is not more limited (pl. IV, fig. 16). It is directly continuous with the covering of the digestive tract (Ludwig, Hamann). The epithelium covers the horizontal portion of the esophagus. It is invaginated in the center to form the internal glandular layer of the digestive tract. Does the nervous layer follows it through its course? Hamann has been able to follow it into the beginning of the esophagus in very young Asterias rubens, but he has not been able to go further: "Wie ihr Verhalten zu den zellen des Mitteldarm und der radiaren Blinddarme ist, konnte ich nich eruiren (20, page 14)". I have repeated his study in adults and in all the species that I have been able to obtain alive. I have obtained a perfectly general result, thanks to the precious reagent of the nervous system, osmic acid. The glandular cells become black, although the nervous substance remains gray. I decide to confirm its existence for each species only when I was able to see clearly the characteristic fibrous structure. As for the direction of the fibrils, Hamann believes that they are longitudinal, i.e., parallel to the axis of the digestive tract. I think instead they are circular. However I will not confirm it in a precise way.

In the esophagus, the nervous zone is about $20 \mu$ thick, more than an eighth of the height of the glandular cells. One finds it in the smallest folds of the esophageal pouches of Echinasteridæ (pl. II, fig. 24, $n$ ).

In the stomach, the nervous zone continually gradually decreases in thickness (pl. II, fig. 22 and $25, n)$. It is nearly a tenth of the total thickness. The glandular cells are full of granules nearly its entire length. The rest is a small filament that goes into the nerve fibrils and goes to attach to the underlying connective tissue. To see this arrangement clearly, it is necessary to choose a time where the cells are empty. One finds a nervous layer in the part below the stomach (fig. 22). 
There remain the glands of the radial caeca and stomach. We have seen that they form very late as extensions of the stomach surface. I have found a thin nervous layer, 1/10 of the total thickness, in the reservoir of the radial caeca of Echinasteridæ and Asterinidæ (pl. II, fig 26, $n$ ). In Asteriadæ and Astropectinidæ, where there is no reservoir, I have found beginning at the median sac to which they are attached the lateral glandular pouches of the caecum, a thin nervous layer, $1 / 18$ of the total thickness, notably in Astropecten aurantiacus. But in all the types, the nervous layer decreases little by little in thickness and it is impossible to find it beyond the first third or half the caecum. Finally, in the true brown glandular part (pl. III, fig. 1), I have never found a trace of fibrils.

In the poorly developed stomach caeca in Astropectinidæ, I have found a nervous layer in their entire length. It is very thin, $1 / 18$ of the total length (pl. III, fig. $2 n$ ). I have never found it in the well-developed glands of the other families. I do not assert the non-existence of a nervous zones because of the special difficulties that prevent a good separation. However, it is very probable that the nervous zone stops at their base.

Finally, to end this study of the nervous system, it remains to speak of the superficial nerve plexus, It is Hamann who discovered it and described it first in young Ast. rubens. I do not know if it is easy to see it in the young, but in the adults, it is necessary to make a large number of sections and dissociations before getting passable results. The big obstacle is the glandular cells that release their secretory product when one touches the epidermis and that hinders the action of osmic acid. However, with much patience and some knack, we arrive at having good preparations. This nerve zone, hidden between the bases of the epithelial cells, coves absolutely all of the epidermis. The fibrils appear to form a plexus looser in the points where we have previously reported them. The nervous zone has a very variable thickness, about $1 / 8$ the height of the epithelial cells. It is a little thicker in the papulae (pl. I, fig. 23,n) and the pedicellariae (pl. I, fig 12,n) that are the most sensitive organs of the body wall.

I have recognized this superficial layer in all species with a soft integument, as Asterias glacialis and Echinaster sepositus, as well as in those whose epithelium is raised on the skeleton like Astropecten aurantiacus (pl. I, fig. 18,n) and Asterina gibbosa. This nervous zone is in direct continuation with that of the nerve ring and radial cords. We see in the sections of the epithelium of the nerve strand is continuous with the ordinary epithelium of the body is considerably thinner. The nerve fibrils follow the path of the epithelium in which they are enclosed.

This superficial nerve plexus that I am going to describe is evidently homologous with that which Jourdan and Hamann have found in holothuroids, and Lóven and Prouho $\left({ }^{5}\right)$ in urchins. But the anatomical arrangements are noticeably different. This is explained by the difference in position of the radial and buccal nerve cords in the latter echinoderms.

I cannot help pointing out the extraordinary resemblance between the nervous system of asteroids and that of actinians that we know from the beautiful works of the Hertwig brothers. We only have to look at their figures, notably the section of the tentacle of Anthea cereus to be convinced of the histological identity of the two systems. I have not wanted to make a strong cononection, but it is evident that those who want to separate the echinoderms from the coelenterates to place them beyond the worms make a grave error. Generally connections based on the nervous system are very valid, and it is impossible to ignore the links that unite from this point of view the lower echinoderms such as the asteroids and perhaps the crinoids to the higher coelenterates such as the actinians and the medusa. A priori, it can seem bizarre that in animals so inferior as the asteroids, the digestive tract has a very developed nervous layer, a kind of continuous

\footnotetext{
${ }^{5}$ Prouho, sur le system nerveux de l’Echinus acutus, Comptes-Rendu, 22 febrier 1886, n 8, pag. 444.
} 
stomach-gastric system. In actinians, we find in the esophageal canal (Schlundrohr) right down into the intestine, a nervous layer passing between the bases of the glandular cells, of which we have already noted the identity with the digestive cells of the asteroids.

A difference to report however is that Herwig figured beautiful ganglionic cells, very developed, often united in a plexus (buccal disk, muscular lamellae of the septum of Anthea cercus). The resemblance with the nervous system of the asteroids is so striking that I have investigaed with great care in the latter the ganglionic cells in different organs. I am convinced that there are only the small bipolar cells that I described above.

The nervous system of asteroids is entirely contained in the various epithelia. All the surface of the body and the digestive tract is covered with it. It is, indeed, entirely sensory. It is, moreover, the character of the nervous system of lower animals. But there are muscles that are in physiological communication with the external epithelium. If one touches the nerve strand as slightly as possible, the adjacent pedicellariae move to try to seize the enemy, the tube feet contract, the spines of the ambulacral groove fall back on it to protect the touched point. It is evident that the pressure felt is transmitted to the muscles of the pedicellariae, the tube feet and the spines. But by what means? All those who have spoken of nerve fibrils going to the muscles have been deceived by false appearances or are based on obvious errors in interpretation. It is impossible to see in the sections these very thin fibrils passing across the thick and compact connective tissue. No one has ever seen them. It seems improbable to me that these are the means that communication is established. In ophiuroids, large nerves come from the radial nerve strand and go the muscles of the arms (Ophiolepis, Ophiocoma scolpendrina). It has been impossible for me to detect a parallel arrangement in asteroids although it is evident there must be some kind of analog.

Sense organs. - The only sensory systems are those of touch and vision. But here I differ completely with the opinion of Hamann. He describes in the exterior epithelium of the pedicellariae, papulae, tube feet and tentacle special cells (Sinneszellen), sensory, more delicate than the other epithelial cells said to support them (Stützzellen) and directly continuous with the underlying nervous layer. It is the same with the cells of the eye.

I am completely convinced that there is no connection between the epithelial cells, sensory or otherwise, and the nerve layer. A negative observation does not have great value, I know this, so I have sought to see in the most sensitive cells possible, if I can express myself this way, i.e., in the eye and the tentacle, how they are connected at their base. I have been able to confirm from the preparations (pl. III, fig. 17 and 21), that the cell is attached by its lower end on the underlying connective tissue. The filament of the cell body is so fine, so delicate, that it often can be broken. But it is not so.

Moreover, is it necessary that the sensory cell be connected directly to the nerve fiber? The excitation will be transmitted just as well if it is surrounded on all sides. Here is a proof that seems decisive and correct to me: the nerve strand, whose cells are less delicate and so clear after treatment with osmic acid that one can follow them one by one (pl. III, fig. 11) to show with absolute certainty that none of its epithelial cells are continuous with the nerve fibers in which they are found. There is thus no sensory cell in the sense understood by Hamann. However, if one touches the nerve strand, even with the greatest care, of an inverted living animal, we see all the surrounding organs contract and move in all directions. The excitation has spread.

We find, in the various epithelia, more or less delicate cells that others that appear identical to the Sinneszellen de Hamann (pl. III, fig. 22, $a$ ). I have found many times that these cells are not continuous with the nerve fibrils. Because of their fragility, whose cause is all mechanical, they are more easily broken than the others and seem to be lost in the midst of the fibers. I think thus 
that these are the accidents of preparation the led Hamann into error and that there are no sensory cells in the sense that he intended. I know well that this is against the generally accepted opinion, but I must express my conviction.

Tactile organs. - The end of the arm is the site of the most delicate sense of touch. The nerve strand ends in Asterias glacialis (pl III, fig.14) in a rounded surface, with a well-defined cushion colored a bright red. Above the ocular cushion is the tentacle that is an extension of the radial canal (Ludwig). It is present in the youngest stages of development as shown by Agassiz (1), Lacaze-Duthiers (29), Ludwig (35), etc. It thus has no relation with a tube foot as is often said. In regenerating arms, it is formed nearly immediately. We see it easily in the bud of 2 to $3 \mathrm{~mm}$. The tentacle and the ocular cushion that it has at its base are sheltered under the ocular plates (radial of Lóven) and are surrounded by a circle of very mobile spines (pl. III, fig. 16). When one touches the tentacle, it quickly retracts and the spines are closed completely to prevent external sensations.

There are also some tube feet for touch. They are longer, lacking a sucker, keeping the undifferentiated character of very young tube feet (pl. III, fig. 15 and 19,a). Naturally, they do not serve at all in locomotion, but they pass gradually to the active tube feet. In Asterias glacialis, the four pairs nearest the median tentacle are thus transformed into tactile organs and are strongly colored yellow. The following four to six pairs are slightly colored with the terminal part very long and thin and pass gradually to tube feet with suckers. In all the asteroids that I have examined some terminal tube feet of also transformed. When the arm advances, they retract the moment they touch an external body to elongate a moment afterwards, like the tentacle of a snail. They have small vesicles like ordinary tube feet.

The epithelium of the tentacle and tube feet is similar. They cells are very delicate. At their base, they are attached to the underlying connective tissue while spreading slightly. We see some whose cellular filament is contracted in a spiral. This is another proof the cells are not continuous with the nerve fibers (pl. III, fig. 21). A thick cuticle with very long cilia ends the epithelium. The nervous zone is nearly half the total thickness, from 70 to $80 \mu$.

The tube feet are very sensitive to pressure, thanks to the thickness of their nervous layer. But these are not organs of touch as is very often said. In fact, the sucker is fixed on a wall that the tentacles explore. Even when the asteroid is immobile, fixed by all its tube feet, the tentacles are constantly in motion.

Some astropectinids of small size (Astr. spinulosus, squamatus) have one peculiarity in regard to tactile organs. When we observe them in an aquarium whose bottom is covered with a thick layer of sand, we see them most often bury themselves completely with some rapidity. The five arms have the eye and the tentacle raised above the sandy layer. In addition, we see elevated from the center of the aboral surface a conical extension of nearly a centimeter in height. This cone, very sensitive, swollen by the liquid of the body cavity, appears to function to alert the animal of the approach of a strange body. In fact, if we touch it, it is retracted rapidly, the aboral surface pbecomes flat and the animal buries more deeply into the sand.

Visual organ. - We have seen, in front of the tentacle, a brightly colored cushion. It is the visual organ, an ensemble of small pigmented masses of bright orange. It is very rudimentary and not very useful. Urchins, comatulids and ophiuroids lack it and live in the same conditions as asteroids.

In Asterias glacialis, the ocular cushion is rectangular (pl. III, fig 14). In other types it is oval (pl. III, fig 16). It is extremely reduced in Luidia ciliaris (pl. III, fig. 15).In order to give a good description, it is necessary to combine studies on living animals with sections and 
separations. The visual apparatus consists of a multitude of small pigmented cups separated by colorless spaces. These cups are slightly hollow and have no lens or any refractory conformation (pl. III, fig. 17). The cuticle (c) that covers the radial nerve cord goes up into the ocular cups that it completely covers. In living animals, I have never seen cilia. The pigmented cells form a dense cover. The largest are naturally the most external. Those in the bottom of the cup are much shorter.

The pigment formed of a bright red granulation is located in the upper and enlarged part of the cell. The granules, very dense at the surface, differ a little at the nucleus (pl. III, fig 18). This always is found immediately below the pigment. It is large, oval, with a refringent nucleolus. Generally it projects onto the lateral surface of the cell, surrounded by a thin protoplasmic layer. The rest of the cell is reduced to an extremely fine and delicate filament, more or less long according to where it is observed. It ends in a slightly swollen end on the underlying connective tissue. When one shreds it in osmic carmine after a long time in distilled water, one can have completely isolated cells and easily confirm all their characteristics. Sometimes the cellular filament has small, separated protoplasmic granules. Very rarely secondary filaments are apparent (fig. 18). Either they go to attach to the substratum or they are lost in the nerve layer. Finally, I have seen some that leave from one point in the cell to go to attach a little lower (fig. 18). These filaments do not exist in all cells, far from it. They evidently function to increase the points of contact with the nervous tissue. The cell has a cuticular layer on its surface that protects it. This layer often has a bizarre appearance. They seem to be obliquely attached to the cells. This is related, as we can assure by looking at the figure of the ensemble, with the place where we consider them. We see some, rarely it is true, that have two of these cuticular plates (fig. 18, $c^{\prime}$ ). Lange and others who followed him, have considered them as small crystals. This is an error. They behave with osmic acid like all the cuticles that we have been able to see so frequently in the digestive tissue and diverse epithelia. In the living animal, we see that they have no special refractory property. Finally, in shredding, I have seen them in perfect continuity with the cuticle of surrounding nonpigmented cells.

The pigment is extremely resistant. It keeps its brightness of color in osmic acid, acids and even absolute alcohol. It is thus very different from all the red pigments that color the external integument.

The space between the ocular cups is occupied by ordinary filamentous cells that are less delicate than the visual cells (pl. III, fig. 17). They are inserted on a very reduced space towards which they converge. The nervous layer contains no more nerve cells than in the rest of the radial cord. It occupies about half of the height of the cells. All the visual apparatus rests on a connective tissue layer, very thick and containing many fibers with a large nucleus.

History. - A large number of works on the visual organs have followed each other since the discovery of Ehrenberg (1834). The concern to find the classical elements, cornea, lens and retina, has nearly always affected the opinions of the authors. At the same time, the erroneous ideas about the nervous system prevented them from understanding the anatomy of the ocular cups.

Mettenheimer, Wilson and Hockel (1860) took the cuticular surface, divided into small polygons corresponding to the underlying cells (see pl. III, fig. 17) for a cornea composed of polygonal cells.

Jourdan (1865) gave a very good description of the eye from the macroscopic point of view. But saw there a crsytal filling the center of each ocular cup.

Lange (1876) described the connective tissue thickening as a ganglionic mass in communication with the pigmented cells. It is the same with Wilson and Jourdain. These are the connective tissue nuclei that they took for nerve cells. 
Ludwig (1878) corrected this error. Hamann (1833) reviewed the knowledge of his predecessors, but he made the pigmented cells continuous with the nerve fibers. His figures are wrong on several points. Finally, I have shown that I am completely not of the opinion of Lange and his successors on the subject crystalline pseudo-bodies.

The only reason I consider this apparatus as visual is the presence of this special pigment, because all the usual formations of the eyes are lacking. Following the expression of Jourdain, it is a photoscopic eye that gives only the sensation of light (Vers), in contrast to the idoscopic eye, forming true images (insects, mollusks, crustaceans).

Organs of hearing and smell. - They are not represented in asteroids. I believe them completely insensible to sound. As for smell, it appears to be very sensitive in stars, because they recognize very quickly the presence of dead prey. It can operate easily across the epithelia, the nerve layer being very near the exterior surface (tentacle).

Physiology. - What is the relative value of the diverse parts of the nervous system? Is it more or less comparable to a brain? Vulpian, in 1866, thought that such was the role of the nerve ring. According to him, when an arm was separated from the disk, it had incoherent movements. The nerve ring was thus a center of coordination. This conclusion, attacked by Baudelot, then by Romanes and Ewart, has been reprised by Hamann, who named the nerve ring the cerebral ring (Gehirnring.). At Banyuls, where the animals are completely acclimated in the aquaria, I have been able to repeat numerous times diverse experiments with these results.

When one separates an arm from the disk, by cutting it for example, at the fourth ambulacral ossicle, one observes sometimes movements of torsion, but this is due to the trouble caused by trauma. These movements soon cease. The arm regains its equilibrium and moves in a perfectly straight direction and attaches to the wall of the aquarium like intact stars do. I have placed arms into the sea in an area where I could easily observe them during calm periods. Not only did they have appearance of animals in good condition but they moved sometimes spontaneously in order to go to shelter under a fragment of rock (Asterias glacialis, Luidia). Most often, arms separated from the disk regain their equilibrium, then remain where they are placed and no longer move (Astropecten, Echinaster).

If one makes a deep cut of the radial nerve cord, the tube feet located on the other side of the cut show uncoordinated movements.

In summary, in relation to the tube feet of the arms, the radial cord plays the role of central coordinator, as one can see a priori by the direction of the fibrils.

On the other hand, if one sections the oral ring of each side of an arm, the arm thus circumscribed executes movements uncoordinated with those of the other arms. The nerve ring plays thus the central coordinating role in relation to the different arms. It is the arm center, while the radial cord is a tube foot center.

Finally, the superficial nerve plexus is sufficient to itself. If, in four cuts with a scalpel, one isolates a rectangle on an arm of Asterias glacialis in good condition, after some time of rest, one can make the papulae of the rectangle contract by irritating the pedicellariae within the same surface. The nerve impulse goes directly to the point excited to the papulae without passing any center. Naturally, the rectangle thus delimited does not feel stimuli of adjacent parts.

History. - I pass over the works of Spix and some others who have mistaken the mesenteric cords for nerve ganglia.

Tiedemann (1815) remarked that when the wall of the orange vessel of the arm (Asterias aurantiacus) was gently raised, one discovered below a very fine whitish, longitudinal filament 
that continued around the mouth with an identical ring. These are the radial and buccal septa of the blood system that Tiedemann took for the nervous system.

Müller (1850) thinks that the very integument of the orange vessel is the nervous system.

Hœckel (1860) began histological investigations. He describes a neurolemma, of simple tubes of the medullary substances. This is a mixture known of all the elements of the nerve strand.

Wilson (1862) took the nuclei of epithelial cells for nerve cells and did not speak at all of fibrils.

Greeff (1871) was the first to approach the truth. One can at least recognize what he describes. He studied sections. Here is what he saw in the nerve strand: ciliated cuticle, flat epithelium formed of small cells, a thick layer perhaps nervous, another epithelium bordering the rdial sinius. Greeff has taken for an epithelial layer the nuclei of the underlying cells. He is not very fixed on the nervous substance that he places both in the thick layer and in the radial septum.

Baudelot (1872) declared that the question remained for him completely obscure in asteroids.

Hoffmann (1874) found in the nerve strand a ciliated cuticle, a pavement epithelium, then the nervous substance of our underlying cells.

Teuscher (1876) was the first to assign a nervous character to the sub-epithelial fibrils but he saw only the nuclei of the underlying cells that he describes as nerve cells.

Finally, if we arrive at more modern works, we see that there are no more than two very different theories, disagreeing on the very place of the nervous system: that of Ludwig that Hamann and I have completed and generalized, and that of Lange that Perrier has reprised recently.

Ludwig recognized that the sub-epithelial fibrils were of nervous nature, confirming the ideas of Teuscher on this subject. He has shown their relation with the filiform cells. Hamann, in a beautiful work, has reviewed the studies of Ludwig. He has discovered in young Asterias rubens the superficial nerve plexus and the nerve layer of the esophagus. I am not of his opinion in a number of points relating to the sense organs and sensory cells, but one cannot disregard the fact that Ludwig and Hamann are the only authors who had some clarity about this very difficult question about the nervous system. A word of explanation is necessary about the theory of Lange. When one examines the section of the radial sinus, one sees that it is limited by a cuboidal epithelium. This epithelium is thickened from place to place on the upper part, either by inherent contractions that results from the procedure used in the study or from some completely different reason. Lange accepted these thickenings were of nervous nature and extended into all the oral ring and the radial sinus, in direct contact with the blood. Finally, the eye rests, according to Lange, on a large optic ganglion. The German author has certainly seen the sub-epithelial fibrous layer and the cells that across it. But for him, it is connective tissue. He called it fibrous Zwischensubstanz.

Perrier, after adopting the ideas of Hoffmann, i.e, that all the arm strand is of nervous nature, has reported (50) recently another point of view that approaches closely that of Lange.

Like this author, he accepted as nerve cells the cuboid epithelium of the radial sinus and those of the septum. At the level of the eye, he likewise said that these nervous pseudo-cells are clearly in relation with the ocular pits. Perrier has incorrectly observed the nerve strand. For him, the fibrous tissue is: "only a membrane of support crossing its thickness by a multitude of fibers already seen in various anatomists that lead on one hand to some cells of the exterior epithelium and on the other hand to the cells that one considers as forming the internal epithelial layer." It is easy to see that the fibers of which Perrier speaks are supporting cells and that he has taken their nuclei for an exterior epithelium, like Greeff and Teuscherl 
Evidence for the nervous nature of the sub-epithelial plexus. - In the studies on the nervous system of lower animals, one meets a grave difficulty. How does one prove that a described part is of nervous nature? Generally it is based on the presence of so-called nerves to demonstrate it. This is wrong. The nerve cells have rarely a characteristic form. They can be confused easily with connective tissue cells. (Lange, Wilson, Romanes and Ewart, etc.). If we put side by side a connective tissue cells and a nerve cell, it is certainly impossible to say, in asteroids and in all other animals, this is certainly of a nervous nature.

But there is a characteristic element impossible to confuse with other histological types that has clear characters. It is the nerve fiber. There is a fibrous layer that Lóven and Prouho have shown in the superficial nerve plexus of urchins and they have correctly not considered the nerve cells as landmarks.

The fibers that we have described are certainly nerves and nothing else. They do not relate to any variety of connective tissue and to the contrary are far from it. Finally, they have a complete identity with the very clear fibrils of the nervous system of holothuroids and urchins. I have found them in ophiuroids with exactly the same characters. The resemblance with the nerve fibers of actinians and medusa is striking. I have already insisted on this point above.

The arguments that one can make from the morphology of echinoderms are no less convincing. It is true that in urchins, holothuroids and ophiuroids, the nervous system is in the interior of the skin and not the exterior as in asteroids. These are embryological questions of highest interest to clarify but the relation with the water vascular vessels and blood vessels is constant.

\section{Blood}

All the internal fluids of asteroids have the same composition, those of the body cavity, the circulatory system and the water vascular vessels. Thus one can give a single description.

The internal environment, following the expression of Claude Bernard, is formed of a fluid having in suspension very numerous structured corpuscles that have been reported for a long time in various echinoderms. There is only one type of corpuscles. These are small cells, 5 to $6 \mu$, whose nucleus is difficult to see alive, with amoeboid extensions that are sometimes very long at its periphery (pl. IV, fig. 11). Their movement is slow. Within one minute, the form obviously changes. These amoeboid extensions, truly amoeboid pseudopods, have the most diverse forms. They are usually slightly isolated or slightly anastomosed. But there are circumstances where they form an extraordinary complex system (Polian vesicles of Asterinidæ and ophiuroids), when the cell is well nourished, for example (pl. VI, fig. 6 shows a very simple system). At other times, the pseudopods anastomose in a way to form rings that touch the circumference. Semper and Geddes report this detail in holothuroids and urchins. The protoplasm that forms the pseudopods is very glassy, although the rest of the cell is granular and contains pigment. This pigment, formed of small colored grains, very refringent, is uniformly distributed in the cell. It is most often yellow, more or less bright, rarely violet (Cribella oculata) or blackish (Astropecten spinulosus). Old corpuscles entirely lack it Young corpuscles have a bright color.

Finally, the cellular protoplasm often has one or more vacuoles filled with a slightly violetmauve color (pl. IV, fig. 11). One finds these vacuoles with a vague color in the germinal spots of the eggs in nearly all species. It is cellular liquid that fills them.

One finds only very few isolated corpuscles. Most often they are united to form plasmodia of a variable size. In these, one still sees vaguely the spherical form of the various cells that 
compose it (pl. VI, fig. 11, and pl. VI, fig. 6). The masses of pigment are no longer mixed. The periphery of the plasmodium emits the usual pseudopods. Often the plasmodium is very large (up to $1 \frac{1}{2} \mathrm{~mm}$, and is visible to the naked eye. One sees them swirling in the tube feet and the papulae, which indicates circulation in these organs. Geddes (14), who described the plasmodia of urchins, thought that they form only when the animal is injured. All the asteroids that I have studied have shown plasmodia at all times, in animals in very good conditions, and I have seen them in living animals without any wounds.

I have seen these same corpuscles, with an identical yellow pigment in ophiuroids and holothuroids (cucumarians and synapatids) where they have the same characters. Fœttinger has given a completely erroneous description of them in Ophiactis virens, where he saw neither the amoeboid extensions nor the constitution of the pigment.

What is the nature of this yellow pigment? Howell and Fœttiger have stated that hemoglobin exists in the blood of echinoderms by means of the microspectroscope. They have localized it in the corpuscles. But it seems to me the question is not resolved in all its details. The pigment is certainly respiratory. There is no doubt there. But is it hemoglobin? It has scarcely any of the microscopic characters. Its varieties, violet in Cribella, brownish or black in some Astropecten, seems to indicate this is a substance near to hemoglobin without doubt, but distinct from the chemical point of view and very polymorphic. To recall its relation and color, I shall call it hemoxanthine. The pigment is destroyed little by little by respiration, because one sees that the corpuscles existing for some time no longer contain protoplasmic granules, without a trace of color.

These are the only structured corpuscles contained in the blood. All those Hoffmann has indicated are the debris of cells that are fallen there accidentally. One never finds them when one take the blood with care. Sometimes, but very rarely, one finds cells full of pigment but not amoeboid. They belong to lymph glands that produce blood corpuscles that have fallen into the blood before complete maturity. But, I repeat, that is a very rare event. I have found it only one time (Luidia ciliaris, water vascular fluid).

The liquid in which these cells are in suspension is sea water, with all the salts that are contained there and with other foreign bodies. When one puts the fluid from the body cavity of an asteroid into a vessel and leaves it alone, one can observe amoeboid corpuscles, no longer moved by cilia, fallen to the bottom of the vessel and that form a very visible layer there. There is no trace of coagulation.

Origin of blood corpuscles or lymph corpuscles. - There is in asteroids a nearly unceasing production of blood corpuscles corresponding to a constant destruction of the same bodies. I anticipate a little here studies that will follow. But I have wanted to have in a single place all the facts relative to the blood that plays a major role in the physiology of echinoderms.

The centers of production of the corpuscles are the glands that I propose to call lymph glands. Their role has been very variously interpreted, often it has been guessed (Teuscher, $\mathrm{H}$. Carpenter, Hamann, Perrier), but none of these author have demonstrated it in a decisive manner.

The lymph glands are extremely numerous in asteroids: the body cavity, the vascular system that is a dependency, and the water-vascular system. The most celebrated is the axial gland that is still the object of many discussions. They are all dependencies producing blood corpuscles to the vascular system and the body cavity. The Tiedemann bodies and the Polian vesicles are related to the water vascular system. I will study here only the production of the cells they contain. Their more detailed histology and their anatomy will be treated in regard to the systems with which the glands are related. 
The schematic of the lymph glands can be defined in the following way: connective tissue frame supporting the cells, rapid multiplication that, once filled with the respiratory pigment can leave the organ the produced it to be spread throughout the fluid (pl. IV, fig. 8 and 10; pl. VII, fig 16; pl. VIII, fig. 8 and 9). The yellow cell has a large nucleus with a refringent nucleolus (pl. IV, fig. 12). The protoplasm is very plentiful and very granular. The pigment begins to be arranged in the form of small spheres of an oily appearance, very refringent, very pale yellow in small numbers in each cell (pl. VIII, fig. 18, j). At this moment, the cell never has amoeboid movements. Little by little, the spheres divide, are multiplied considerably and deepen in color. At this completely ripe state, the cell is entirely filled with fine bright yellow granules that could make one believe the color is uniform (Fœttinger) and one mass in the cell. But with good objectives with immersion, one distinguishes perfectly the separate granules. Well before this state, as soon as the color becomes a little brighter (pl. VII, fig. $9, l$ ), the cell emits into the gland some amoeboid extensions (pl. IV, fig. 10; pl. VI, fig. 7 l; pl. VII, fig. 17). When it has matured, it leaves the gland by pushing through the connective tissue (pl. IV, fig 10, $d$ ) and falls into the fluid. It has some ordinary amoeboid extensions with all their variations. The cells are isolated or form plasmodia like those I described in the blood (pl. IV, fig. 12, cs; pl. V, fig. 4; pl. VIII, fig. 9, l). Sometimes in well nourished cells, at the moment they leave the gland, emit a very complex pseudopodia (Polian vesicles of Asterina and ophiuroid), but these soon return to the ordinary type.

We easily recognize that a lymph gland is at maturity by a deep brown or black (Astropecten spinulosus) or violet (Cribella, Echinaster) color. We only has to detach a fragment with scissors to examine it in aerated sea water, avoiding compression of the coverslip, with a 20 to $1 \mathrm{~mm}$ Nachet to recognize the correctness of my description. We sees very well the connective tissue frame of the gland, the kind of cells and their different characters.

Development of the corpuscle. - The blood corpuscle thus constituted lives for a time impossible to determine, but should be very short. It fills the functions assigned to it and that I am going to examine soon. Little by little, its pigment disappears, the colored granules decrease in number. Soon there remain only a few. Finally it becomes entirely colorless. Its nucleus becomes apparent because of the loss of the pigment that hid it. Abundant vacuoles are in the protoplasm. Then it dissolves and disappears in the blood. It is replaced by another generation of cells from the lymph gland that begin a new cycle.

Origin of the liquid of the body cavity. - We have seen that the asteroid has a large number of papulae with extremely thin walls. I have given the description the anatomy of them in the preceding chapter. Through these organs as through any thin membrane, there is extremely active osmosis between the blood and the sea water. We can thus explain easily by an experimentation as well as what is evident by reasoning. If one places an asteroid into sea water containing aniline, which is harmless to the animal, and leaves it there for some time, we observe that the papulae are very colored. On the internal wall of the body wall, the borders of the papulae is equally colored. The fluid of the body cavity has a coloration like that of the surrounding fluid. If one replaces this asteroid into pure sea water, we observe the inverse phenomenon. All that had been fixed by the blood cells return into the surrounding water. This is no introduction of liquid by the stone canal. I shall reserve the discussion of this important fact to after the anatomical studies. It is thus by way of the papulae that active osmosis occurs between the two liquids. The wall of the tube feet, when they are extended, likewise has osmosis, a little less rapid naturally because of their greater thickness. Finally, in species of small size, there can be some exchange across the horizontal portion of the esophagus. 
Respiration and excretion. - The blood cells are constantly moved by the cilia of the cavities where they are found. Their pigment (hemoxanthini) fixes oxygen like hemoglobin and is distributed throughout the organism. Carbonic acid, produced by metabolism is dissolved in the blood and escapes by diffusion. In fact, we do not find it dissolved in the blood.

The products of breakdown, urate, uric acid, guanine, etc.., are dissolved in the body cavity. As they are salts, they leave the organism likewise by osmosis, across the papulae. Iin fact, we do not find any excretory organ in asteroids. The axial gland is sometimes given this role (Perrier, Koehler, Apostolidès, Hamann) has an entirely different function. It is a lymph gland as we have seen. The stomach caeca are digestive organs and nothing else. A priori, in animals whose organs and internal fluids are in continuous and easy osmosis with sea water, it is not necessary to have an excretory organ because it is by osmosis that the products of breakdown and carbonic acid leave the organism.

The comparative anatomy of echinoderms gives from this point of view a new proof of great value. In each of the five families are organs that provide osmotic communication between sea water and the liquid of the body cavity. In urchins, it is the intestinal siphon (Perrier) and the buccal gills. In ophiuroids, it is the respiratory sacs (Ludwig, Apostolidès). In asteroids, it is the papulae. In holothuroids, it is the respiratory trees. In crinoids, it is the ciliated funnels and the water-vascular system and their extensions (Ludwig, Perrier). These are the different anatomical arrangements all having the same physiological function, to establish continuous and easy exchanges between the two liquids that these organs separate. Perrier's (45) experiments proved that there is a current of water in the intestinal siphon of urchins Those of Apostolidès, which I have repeated at Roscoff, that water is constantly moved into the interior of the respiratory sacs, true invaginated gills, into the body cavity. All those who have observed holothuroids at the sea shore have easily confirmed the entry of water into the respiratory trees. Finally, according to Perrier, Carl Voogt and Yung, water enters by the ciliated funnels of comatulids and goes throughout the organism and leaving by the syzygies.

I know well that the water-vascular system of comatulids is homologous to the watervascular system of urchins, asteroids, ophiuroids and holothuroids. But we have seen many times when homologous organs have different functions. It depends on the anatomical arrangement. I consider it certain there is no entry of water by the madreporite, at least in a useful way. But I do not want to anticipate a following chapter.

Nutrition and assimilation. - We have seen that the respiratory pigment is located in the blood corpuscles. But these corpuscles have another role, perhaps still more important. The products of digestion, peptones or others, pass naturally into the fluid of the body cavity by simple osmosis. But it evident that they do not stay there. We know that they are very soluble substances, with a very great diffusion capacity. They thus would pass across the papulae as they cross the walls of the digestive tract, No particular arrangements stops them. All the digestive work thus would be wasted. This is inadmissible. What is thus the part that absorbs the digestive products? This role can be given only to the blood corpuscles. Very numerous, very active, they absorb all the soluble products that without them would escape into the sea water. We can easily prove this by placing aniline or colored granules into the body cavity. After a short time, the lymph cells have entirely absorbed them, the fluid does not retain a trace. But that becomes of these nutritive products that the corpuscle has thus assimilate. It should use part of it for its own account and return the rest when it dissolves in the blood at the end of its life. It probably restores it in a form very resistant to diffusion, such as albumin. I have not been able to make direct investigations on this subtle point that requires inspired experiments. I have no more demonstrated the absorption 
of peptones by the corpuscle nor their chemical transformation because it is impossible to feed the asteroids with special prey at the moment one desires. In other animals, I hope, in the next work to present a clearer demonstration on this point of physiology, whose importance will escape no one.

Everywhere we find a lymph gland, nutrition is assured for adjacent parts because it will have abundant production of albumin. The organs that have a rapid development, like the ovaries and the testes, are in direct relation with an important system of lymph glands as we have seen in the study of circulation.

What I want to clarify is that the blood strictly speaking contains no substance (other than the salts of sea water) dissolved in a constant state, that the nutritive particles are localized in the amoeboid corpuscles and that respiration and excretion operate by simple diffusion across the papulae.

History. - I shall end this chapter with a historical word. In a note in the Comptes Rendus of 28 June 1886, I reported the function of the Tiedemann bodies, the Polian vesicles and the axial gland, in describing the transformation of blood corpuscles. Perrier has claimed for himself the priority of this discovery with the axial gland (note of 17 January 1887). I want to make some comments on this subject. Numerous authors have sought for a long time a relation between the pigmented corpuscles of the blood and the axial gland. Greeff and Teuscher reported pigmented masses in the axial gland a long time ago. Hamann has given an analogous idea while making a mistake on the true function of the pigment. H. Carpenter (5) has said in a very explicit way that it was probable that the axial gland produced the pigmented corpuscles of the body cavity. Perrier, after a study on Asterias Hyadesi, published 21 May 1886 (50), says without other explanation that the axial gland produces the corpuscles of the body cavity. As the animals he studied were preserved in alcohol, it is only by imagination that he advanced this fact because it is impossible to prove this except in living animals. I pass over in silence the numerous errors that led to this conclusion.

I readily recognize that all the authors cited have approached more or less the truth. But the fact remains that it was I who first saw and demonstrated by direct study in numerous living species the transformation of the cells of the lymph glands into blood corpuscles as well as their correct histology.

As for the name of plastidogene bodies proposed by Perrier (note of 17 January 1887) for the axial gland, it is bad from the specific point of view, because the Tiedemann bodies and the Polian vesicles also produce plastids. If it is a generic name, I shall point out to Perrier that I have used the name lymph glands that appears to me more explicit (note of 3 January 1887). I have preserved the name axial gland, used for the first time by Perrier in 1875 because it is convenient as well as that of the stone canal. These names, meaning nothing, have the advantage of not introducing false ideas into science.

\section{Water-vascular system.}

Asteroids have several vascular cavities constituting two systems that I consider as perfectly distinct and without relation to each other. The first relates to locomotion. It is called the water-vascular system. The second is a dependency of the body cavity but is separate in the other echinoderms. It is the vascular or haemal system, as we shall to call it.

The first has been known in general details for a long time. Tiedemann and Jourdain were the first to elucidate its anatomy. It is composed of an oral or upper ring, with a radial branch in 
each arm and a calcareous tube, the stone canal, that opens to the exterior by a plate riddled with small pores, the madreporite, always located in an interradius. There is a variable number of lymph glands attached to the oral circle. These are the Tiedemann's bodies and the Polian vesicles. The radial branch has small lateral vessels at the intersection of the tube foot and the ampulla. These are the known facts that I summarize briefly.

The second system is formed of an oral ring, located above the water ring and also with an upper radial water canal in each arm. From an aboral ring, it has ten branches that surround the gonads. These two rings are united by a vast sinus that contains the stone canal and the axial gland. Finally, the oral ring opens into the body cavity by five interradial openings. Each radial water canal behaves in the same way with as many openings as there are ambulacral ossicles, less one.

In all my figures, I have represented in red, like Hoffmann, the haemal system and the water-vascular system in blue.

Histology. - I have little to say about the general histology of the radial canals. They are lined with a ciliated pavement epithelium ( $\mathrm{pl}$. IV, fig 7,b). A slightly differentiated connective tissue layer limits it. The constitution of tube feet is the same everywhere (Hoffmann, Ludwig, Hamann): the internal epithelium of the tube foot, a layer of longitudinal muscles, a very thick connective tissue layer and finally the external epithelium with its nervous zone that we have studied previously (pl. VIII, fig. 10). The ampulla has the same makeup except that the muscles are circular and that the external layer is replaced by a peritoneal epithelium.

At the point where the transverse vessel of the tube foot and radial water canal meet ( $\mathrm{pl}$. IV, fig. 6; pl. VII, fig. 10) is a valve discovered by Jourdain and very well described by Lange. The radial water canal has a conical opening whose borders are free in the larger transverse vessel. When the fluid of the tube foot is compressed, it lowers the free borders onto the opening and thus prevents the contents of the tube foot from entering the radial vessel. This is of the greatest importance for the physiology of the ambulacral apparatus. In pl. VIII, fig. 10, the section is directed exactly through the center of the opening. In pl. IV, fig. 6, the section is a little tangential so that it crosses the larger transverse vessel and does not encounter the opening. By comparing these figures with those of Lange, who gave a horizontal section (30, taf. XV, fig. 5), the arrangement of this valve is clear.

In transverse sections, we see that the radial vessel is surrounded by a very thick layer of connective tissue fibers (pl. VI, fig. 1) that are easily broken so that it often appears to be on top of a very spacious cavity that is absolutely an artifact. In longitudinal sections, it is slightly uondulating (pl. VI, fig. 5), concave where it passes between two ossicles, converse when it passes above the muscles of the ossicles.

The radial blood sinus $(s)$ is also undulating, but in the inverse direction so that these two cavities are sometimes very close in the inter-ossicle space (pl. VIII, fig 10). In large species, Astropecten aurantiacus for example, the undulations are so great that we see in the same transverse section two lumina of the radial water canal (Teuscher). This is a simple accident of preparation. We are convinced of this by longitudinal sections.

The oral ring follows the contour of the pieces of the mouth. In an interradius (pl. V, fig. 13), it gives rise to the stone canal. It generally has lymph glands. Some form an irregular spherical mass in the interradii that are very brightly colored. These are the Tiedemann bodies, constant in the species we have studied. The others are Polian vesicles, large transparent bladders with long pedicles. They are missing in some families.

The Tiedemann bodies are formed of a series of tubes that converge toward their point of attachment to the oral ring. These tubes, generally little branched, are lined with a cuboidal 
epithelium that lies directly on the underlying connective tissue layer (pl. IV, fig. 8). We always find, in transverse sections of the tubes, their lumen obstructed by a pack of cells $(l)$. These are parts of the cuboidal epithelium that detach with great ease. The protoplasm of these cells is strongly granular, with a large nucleus and nucleolus. In vivo, we see that they have a yellow pigment and that they produce numerous amoeboid extensions. The Tiedemann bodies are thus lymph glands. The blood corpuscles produced by the detachment of the cuboidal epithelium are distributed throughout the water-vascular system. Hoffmann, Ludwig and Hamann have noticed these cellular masses that fill the tubes of the Tiedemann bodies. But they thought that the cells probably divide at this point. In any case, they are produced by detachment of the cuboidal epithelium. Hamann attributed an excretory function to the Tiedemann bodies.

With a completely different appearance, the Polian vesicles have the same functions as the Tiedemann bodies. I take as my example Astropecten aurantiacus, which has very large ones (pl. VIII, fig. 3,p). The vesicle is always hollow. It is on the internal wall that we find the active part. In its cavity, we notice numerous plasmodia, visible to the naked eye, produced by the vesicle. These plasmodia, not being moved by cilia, fall to the bottom of the bladder and pass into the water ring only by contraction of the organ. In spite of its thinness, the wall is formed of four layers (pl. VIII, fig. 9): an external ciliated (e) peritoneal epithelium; a connective tissue layer formed of elastic fibers with large nuclei $(f)$; in this zone and attached to the external epithelium we find numerous longitudinal muscle fibers $\left(m^{\prime}\right)$ of which we see only the cut end; a layer of slightly intertwined circular muscles $(\mathrm{m})$; finally the secretory part formed of a fibrous net bordering some kinds of continuous cavities, crossed in all directions by connective tissue fibers. The cavities enclose sparse cells $(l)$ that are dividing and have a yellow pigment. They finally become amoeboid in the interior of the fibrous net (pl. VI, fig. 7, l), from where they leave to fall into the liquid of the vesicle.

All the Polian vesicles have nearly the same constitution. In small species, the muscle layer is much less developed and has only the circular fibers.

I have found that the Polian vesicles of ophiuroids have the same role, but these are more compact glands than $t$ hose in asteroids. The Polian vesicles of holothuroids are also the site of production of blood corpuscles, combining this function with that of a reservoir of tentacular fluid.

Stone canal. - The stone canal is in one interradius. It is a tube membranous at its base and containing calcite that makes it rigid. In the interior, we find calcareous folds, whose arrangement is as variable as the exterior of the tube. At the lower or aboral end, the canal is attached to the madreporite. The calcareous folds go up to the madreporite with which it is continuous, so that in some species (Astropecten, Luidia, pl. VII, fig. 1) we cannot tell where the plate begins and where the canal ends. Most of the madreporite pores open into the stone canal, the others into the peripheral cavity of the haemal system (pl. VI, fig 10). In most species with a large madreporite, the stone canal has a peculiar organization (pl. VI, fig. 1; pl. VII, fig. 1). On the internal side it has a long pouch $(d)$, flat and membranous, that collects all the madreporite tubes that otherwise would open into the stone canal. Above this ampullar cavity is another much larger cavity $(h ')$ that encloses the end of the axial gland that belongs to the haemal system. The madreporite pouch is found in Asteias glacialis and rubens and in Astropecten aurantiacus. It is nothing like this in the other species where the stone canal is nearly the same diameter as the plate.

Greeff and Ludwig have described very incorrectly this arrangement. They figure sometimes three pouches, sometimes two. There is actually only a single cavity.

Besides this very simple madreporite with few pores of Asterinidæ and Echinasteridæ, those of the other families are very complicated but the organisaton is always the same. Perrier 
made an error (50) in saying the plates result from folding of the walls of a single original pore. We know from the beautiful studies of Lovén that beside the first pore is hollowed out a second, then a third and so on. Little by little, these perforations anastomose in a way to make an ensemble as complex as we seen in adults. As for the histology of this apparatus, it is very simple. The stone canal is formed of three layers, an exterior peritoneum, a middle calcareous reticulated tissue and an internal layer composed of an epithelium with tall ciliated cells. The exterior epithelium of the body between enters into the pores to a certain depth. All the part between it and the ciliated epithelium of the canal is formed of cuboid cells with small cilia (Ludwig, Hamann). At the surface of the stone canl are attached some membranes that connect it to the walls of the haemal sinus that it surrounds. But, as Perrier (50) and Carl Voogt and Yung have said, there are never perforations making a communication of the stone canal and the surrounding parts, no more at the base than at the top.

We are going to examine the diverse modifications of the water-vascular system in the families that I have been able to study. We can bring together genera that we have believed very far apart. It will be logical to begin the study with the asteroids with two rows of tube feet. But we shall see that the phylogeny is far from agreeing with the ontogeny, and that the relations of these two developments are mixed more than once.

Asteriadae (Asterias rubens and glacialis). — We know that the Asteriadæ with four rows of tube feet have no more than two when young. It is a compression and an arrangement of the tube feet that is far from being regularly arranged, as we can be convinced by looking at fig. 1, pl. IV. Two contiguous arms are generally symmetrical in relation to a vertical plane passing through the interradius between them (pl. IV, fig. 2). But it not always thus.

The tube feet have, when we examine them with great care, two very clear white lines placed opposite each other that go from the base up to the sucker (pl. IV, pl. 4). These are haemal vessels that we can inject. They are apparent especially on the tube feet nearest the mouth. The water ring has two small Tiedemann bodies in each interradius (pl. IV, fig. 1, $t$ ). The interradius of the stone canal most often has only one located to the right when one examines the internal surface from the mouth, as in figure I.

The stone canal has been known for a long time (von Siebold, Jourdain). It has in its interior a fold in the form of a $\mathrm{T}$ whose branches are curled onto itself one and a half times (pl. V, fig. 2, $c$ ). In the young, the vertical lamella is simply bifurcated at its end (pl. IV, fig. 14). It is a form that we will find very often in diverse families. In one section, I have found a stone canal (pl. IV, fig. 13) whose vertical lamella is attached to the opposite wall. It is a form we find again in Gymnasteria carinifera. Finally, a very tall and very ciliated epithelium coves all the concave parts of the calcareous fold and the canal (pl. IV, fig. 15), while a shorter epithelium covers all the convex parts. No author has reported this difference between the two epithelial coverings.

Echinasterida (Cribella oculata, Echinaster sepositus). - Asteroids with two rows of tube feet. I have been able to see only a single vessel placed on the external side of the tube foot (pl. V, fig. 7), but these vessels are so difficult to see in vivo and so difficult to inject, that the second perhaps escaped me. The ampullae are slightly bilobed (pl. V, fig. 8). The water ring is bilobed with nine Tiedemann bodis arranged as the Asteriadæ. The stone canal in Echinaster sepositus encloses a simple vertical lamella slightly swollen at the end (pl. V, fig. 6), not reaching a quarter of the cavity. It is a very rudimentary stone canal. Ludwig described a nearly similar arrangement in Echinaster fallax. In Cribella oculata, the vertical lamella is a little less simple. It has the form of a $\mathrm{T}$ with short arms. The madreporite, in this family, is also not very complicated and has only a small number of pores. 
Linckiadce (Ophidiaster chinensis). — The water ring has the same characters (pl. VI, fig 2). The cylindrical stone canal has, as it seems to me, an arrangement analogous to that of the Asteriadæ. I recall that Viguier has found in Ophidiaster pyramidatus a globular stone canal, filed with a lining of calcareous leaves. In this family we fine a crown of spicules in the tube feet, as in urchins (Viguier).

Asterinidae (Asterina gibbosa and Wega, Palmipes membranaceus, Solaster papposus). As one goes down the series and is separated the most from the type of Asteridaæ, we note a real complexity of the water-vascular system.

The water ring follows the contours of the buccal pieces (pl. V, fig. 13, 14). In each interradius, it has two small Tiedemann bodies $(t)$ and below them a Polian vesicle $(P)$ with a very long pedicle that floats in the fluid of the body cavity. At the interradius of the stone canal, there is no longer the right Tiedemann body, but it is not necessary to believe that this has morphological significance. It is a mechanical fact. The stone canal, attaching onto the wall, prevents the lymph gland from developing. Romanes and Ewart, in their study on Solaster papposus, called the Tiedemann bodies "The first series of ampullae". It is useless to say that the glands have no relation to the ampullae.

I have seen only a single vessel on the external side of the tube foot as in the Echinasteridæ. Each tube foot, instead of a single ampulla, has two, one above the other (pl. V, fig. 15). This is not an apparent division. It is perfectly real. The two ampullae do not communicate completely with each other except at their base (pl. VI, fig. 14). We can burst one without the other deflating. When they are filled with fluid, their duality is still clearer. The first tube foot alone has a single ampulla. The interradial wall fills most of the place. There is no space that is necessary for a second ampulla. Palmipes has double ampullae up to the end of the arms. The body cavity is prolonged up to the angles of the pentagon of this singular animal (pl. VI, fig. 14). In spite of its aberrant appearance, it is a very normal asteroid that has exaggerated the characters of the arms of Asterina gibbosa.

The stone canal is very simple in this family: a simple fold in the form of $\mathrm{T}$, more or less developed according to the age of the individual (pl. VI, fig. $3 c$ and 4 . The madreporite has a small number of pores.

Culcitida (Pentaceros turritus, Gymnasteria carinifera, Culcita coriaceu). - The characters of this family greatly recall those of the preceding, the same arrangement of the water ring (pl. VI, fig. 15), two ampullae for each tube foot except the first, the same lymph glands of the ring, and Polian vesicles with a long pedicle. In these three species, there are calcareouos spincules in the tube feet forming, as in urchins, a cross at the lower surface of the sucker (pl. III, fig. 23). Viguier was the first to report them. Gymnasteria appears to me to have very bizarre tube feet. The sucker has a very denticulated appearance. Is this due to contractions caused by the alcohol? I doubt it. I have represented, fig. 23, the sucker of this species taking account of artificial contractions. We see clearly the calcareous crown and the number of scattered spicules in the body of the tube foot. These spicules usually have the form of two pitted plates connected by a handle (pl. III, fig. 24).

The stone canal has some very great differences. In culcitids, it is filled with a large number of irregular folds (pl. VI, fig. 16, c). In Pentaceros and Gymasteria, the vertical lamella divides into two with two folds turning onto themselves (pl. VI, fig. 19). This recalls the Asteriadæ.

Astropectinidæ (Astropecten, Luidia ciliaris). - There is, so to speak, no absolutely common characters. This is a very curious family by the diverse phases of development that it has, fixed in different species. 
In Luidia ciliaris (pl. V, fig. 19), each interradius has two large Tiedemann bodies, colored brown and so separated that they appear rather to be in the radius. A Polian vesicle is nearby. In the interradius of the stone canal are two Tiedemann bodies.

In Astropecten hystrix, spinulosus, squamatus and Platyacanthus (pl. VIII, fig. 1) are the same two Tiedemann bodies and one interradial Polian vesicle. At the-level of the stone canal are not only two Tiedemann bodies but two Polian vesicles, one on each side of the calcareous tube. We see that this a tendency completely inverse of that we have found up to here.

In Astropecten auranticus (pl. VIII, fig. 3), there is a veriable number of Polian vesicles, two, three and four per interradius, in all without exception. The most frequent and characteristic is three. We sometimes see two vesicles on the same pedicle or only one with two excretory tubes. I refer to the monograph of Carl Vogt and Yung for more details of this arrangement.

The tube feet have some variations. In Astropecten aurantiacus and Luidia ciliaris, I have been able to see and inject the two haemal vessles they have (pl. V, fig. 18), as in the Asteriadæ. Observation is made easier by the large size of the animals. In Luidia ciliaris (pl. VI, fig. 25), the tube feet have a very rounded end without a sucker. However, they are able to attach easily, it is true. We see sometimes, in the aquaria at Banyuls, Luidia climbing on the vertical surface of the glass. This animal mainly uses its appendages to move with some rapidity. The ampulla is strongly bilobed. This is a transition to the form of Astropecten. In these animals, the tube feet are conical at the end, hollow and incapable of attaching (pl. V, fig. 18). There are always two ampullae that are clearly separate, even at the first tube foot.

The stone canal in this family has some interesting peculiarities. Iin Astropecten platyacanthous, spinuiolosous and squamatuos, it is divided into two equal parts by a complete vertical septum with two opposite forms in the form of an anchor (pl. VIII, fig. 4). We can compare this form with two stone canals to asteroids superimposed by their grooved surface. If we study development, we see that in young Astr. squamatus, with $\mathrm{R}=12 \mathrm{~mm}$, it is a tube with simply one fold forming a T (pl. VIII, fig. 5). This is a fixed phase in the Asteriadæ and Asterinidæ. A little after, the fold reaches the opposite side where it fuses. The rest of development is easy to understand. In young Astropecten aurantiacus, according to Carl Vogt and Yung, we find again the fixed form in adults of the three preceding species, i.e., two separate canals, each with an anchor. Little by little, this arrangement is complicated by the addition of other calcareous trabeculae, irregularly arranged. As the animal ages, the original arrangement is masked more and more. The section represented by Carl Vogt and Yung (66) shows perfectly the aspect in an adult. Finally, in Astropecten hyatrix, the stone canal (pl. VIII, fig. 6) is filled with fewer lamellae, but still more irregular than in the preceding species. In Luidia ciliaris, the stone canal begins as a thin, membranous tube (pl. VI, fig. 21 and 23), with some calcareous plates in the walls. Then the tube enlarges, becomes globulose and filled with calcite arranged without any order. The stone canal narrows a little at the madreporite. When we make transverse sections (pl. VI, fig. 22), we see that the cavities are lined with a tall ciliated epithelium, sometimes a simple pavement layer without our being able to note any regularity in their distribution.

We sees that it is not without reason that I said previously that phylogeny does not agree with ontogeny. The Astropecten that have a lower position on the ladder tjam the Asteridæ, have as young the phase that characterizes the stone canal of this latter family, then passes it. Luidia, below Astropecten by characters of the digestive tract and ampulla, has the most complicated canal of the group.

The ampullae begin by being single and then is so greatly bilobed that it really becomes double. It is in the Asteriadæ, perfected animals, that we observe the simple form, and in 
Astropecten, lower animals, that we find the complicated form. I only report these facts in passing, without pretending to make premature conclusions.

Physiology. - The current ideas in science on the subject of the water-vascular system seems to me singularly exaggerated. Jourdain, Perrier etc. seem to think that sea water is introduced into the organism by the madreporite and that it is like this in all asteroids. It is not so. I know there are strong cilia in the stone canal. But these cilia force the surrounding liquid in all directions and do not produce any current. I have often observed under the microscope the detached stone canal and I have never seen colored particles in contact with it enter by one end and leave by the other. On the other hand, if sea water enters into the water-vascular system, where does it go? The watervascular system behaves like a thin-necked bottle full of sea water sealed with a porous barrier immersed in sea water. It is evident that exchange of the two liquids would be minimal.

Observation of living animals shows us that the madreporite is not the seat of any water current, neither in (Jourdain, Perrier etc.) nor out (Williams, Hamann). In fact, when we put an asteroid in an aquarium full of powder, we would see these accumulate on the madreporite, if the water was drawn by the cilia. This is not so. The plate is never covered with foreign bodies. On the other hand, the stone canal of Luidia, Astropecten etc. is truly completely obstructed by its calcareous folds (pl. VII, fig. 1). It is impossible that a current is established under these conditions. Finally, if we place an asteroid into an aquarium filled with colored water, we see that it does not penetrate at all by the stone canal.

I do not suggest that sea water never enters by the stone canal, mostly in small species. But the movement of this water that cannot enter the canal is truly negligible. The volume of water contained in the water-vascular system is always the same, thanks the valvular system discovered by Jourdain and Lange. Moreover, it encloses numerous blood cells. This proves that there is no current of water with the exterior. Finally, in adult holothuroids, there is no madreporite. The stone canal opens into the body cavity.

What is the role of the stone canal? I think it has none in the adult. If we remove the lower wall of an asteroid and we close the stone canal by tying it, the animal moves as before. This does not support any perturbation. The stone canal and the madreporite are a memory of the ciliated chambers of the comatulid and have only a completely secondary function.

All authors agree in giving Polian vesicles a role very analogous to those of the ampullae. These organs contract rhythmically to move the liquid into the circulatory and radial vessels. This is by no means correct. It is true that in Astropecten aurantiacus they have a very strong muscular tunic, but their contractions (that I have never seen) simply have the function of moving the blood cells they produce into the water-vascular system. Their form, their anatomy, their special functions all speak against the preceding idea. Finally, they are lacking in some families. If one stimulates the surface of a Polian vesicle (Astropecten aurantiacus) with a needle, we cause it to contract. All the liquid it contains goes into oral ring that greatly inflates and remains in this state for a long time. This proves two things: $1^{\circ}$ that all the water-vascular system behaves like an apparatus filled with water to which we cannot add any. $2^{\circ}$ that even if the internal liquid is submitted to pressure, it cannot leae by the stone canal, whse calcareous folds complete obstruct the cavity. Romanes and Ewart have equally noted in Solaster papposus that a very strong pressure, prolonged for a long time was necessary for a liquid injected into the radial vessel to reach the madreporite.

\section{Haemal vascular system}


I take as example an asteroid with two rows of tube feet, Asterina gibbosa or any Astropecten. I said previously that this apparatus is composed of two parts, one oral and the other aboral, united by a vast interrdial sinius. We concern ourselves first with the lower or oral part

When we examine an asteroid in the morphological position we hav assigned it, we see (pl. $\mathrm{V}$, fig. 17) that the middle of the ambulacral groove has a wide strand that appears to give a transverse branch to each interambulacral space $(s)$. This is the orange vessel of Tiedemann, the epithelial-nervous strand that we have studied before. Under this strand is a cavity. If we insert a needle of small size, or better a needle of Pravaz, and we carefully make an injection, we see it fills all this radial sinus. Then the injection goes into the oral ring from which it fills the radial sinus of the other arms. The radial sinus has, when one examines the median line with care, a whitish line that the injections has not penetrated. This is the trace of a connective tissue septum that separates its cavity into two. Before each tube foot we find a branch perpendicular to the radial trunk. All these transverse sinuses empty into a marginal sinus $(u)$ that borders the ambulacral groove. The latter, after having slightly passed the level of the first tube foot and receiving the transverse branch that passes above it, is lost in the connective tissue.

At the level of each tube foot (pl. V, fig. 18), a thin vessel is detached from the radial sinius. Another, opposite it, is detached from the marginal sinus (pl. V, fig. 7. They run on the tube foot up to the sucker where they end in a ceacum. We can show by sections that they are found in the connective tissue of the tube foot. In large species, Luidia, Astropecten and Asterias, I have seen two of them that I am going to describe. But in Asterinidæ and Echinasteridæ, I have been able to inject only those that detach from the marginal sinus.

The oral ring forms a large circular sinus located under the nerve strand. We also see on its surface ( $\mathrm{pl} \mathrm{V}$, fig. 17, r) a whitish line, marking a septum that separates its cavity into two superimposed parts. This septum is continuous with that of the radial sinus (pl. VI, fig. 5, $s b$ ). The oral ring sends some short diverticula into the connective tissue layer of the esophagus (pl. V, fig. 17), but this not constant. At each interradius (pl. VII, fig. 2) it has a branch that descends nearly vertically and goes between the abductor muscle and the buccal pieces $(y)$ and the connective tissue that it surrounds on one hand and the supporting interradial or odontophore on the other. This branch then opens widely into the body cavity as we can see in pl. VIII, fig. 2. That represents a vertical section passing by the interradial opening.

We have seen the distribution of the haemal sinius in the arms. At the level of each tube foot, there is an opening limited by the ambulacral and adambulacral pieces that border the ambulacral groove. In each opening (pl. V, fig. 18, o'), the marginal sinus sends a branch that crosses the ambulacral axis towards its base and opens then into the body cavity of the arms. Perrier and Poirer have reported these ambulacral openings in Asterias rubens and glacialis (52). In the figures related to it (pl. IV, fig. 5; pl. V, fig. 8, 15, 18, 19), we see in $o$ ' at the base of the ambulacra above the ampullae a colored net resembling a vessel. This is what we see in the injections. The colored material escapes from the opening into the surrounding tissue, giving it the appearance shown in my figures, but in reality the opening of communication is located a little more deeply. We see thus that at each tube foot is a corresponding ambulacral opening, except at the first. As it crosses a full piece (formed by the fusion of two ambulacra), there is no preformed opening, and the marginal sinus does not send a branch corresponding to the first tube foot. We could believe that the interradial opening corresponds morphologically to the fusion of the two ambulacral openings belonging to the first tube feet of two contiguous arms. It is not so. While the interradial branch comes from the oral ring, the other branch comes from the marginal sinus. Moreover, they do not have similar relationships with the calcareous pieces. I do not insist any longer on this point. 
Sections allow us to confirm and complete this presentation. They are not always very easy to do, especially in large species where they had led to errors. It is better to use Asterina gibbosa or a small species of Astropecten.

In a transverse section of the arm, tangential to a tube foot (pl. VI, fig. 8), we see above the nerve strand $(n)$ that continues onto the tube foot. Below it is the radial sinus $(s)$, separated from the nerve strand by a thin connective tissue layer and by a ciliated pavement epithelium that is the direct continuation of that of the body cavity. Still below it, the section of the transverse ambulacral muscle $(x)$ and finally the lumen of the radial water canal $(b)$. On the sides we see the oval section of the marginal sinus $(u)$ beyond the tube foot. The lumen of the radial sinus is always crossed by a septum with a form that is species specific. In Asterina gibbosa and Palmipes, it is very thin and has scattered nuclei on its surface (pl. VI, fig. 8). In the Asteriadæ and the Astropectinidæ, it is a very thick lamella that is perforated at the level of each ambulacral interval by a wide hole whose borders are connected to the walls of the sinus by an oblique septum (pl. VIII, fig. 10, $l$ ) so that the radial sinus appears to be formed by the superimposition of three cavities.

Whatever its form, this septum is continuous through the radial sinus and is inserted on another septum that runs through the entire oral ring (pl. VI, fig. 5, sb). This is thicker, placed obliquely in a way to separate this circular sinus into two unequal parts. The larger is external. It goes to open into the body cavity by the interradial opening described previously (pl. VIII, fig. 2). The smaller is more internal. It produces the interradial sinus (pl. IV, fig. 16, $r$ ').

In one interradius, we find a large sinus that goes down towards the lower surface. It has several names, Schlauchformige kanal, perihaemal axial canal (Ludwig) and hydrophoric sac (Perrier). I call it the axial sinus or glandular sinus, because it contains in its interior not only the stone canal but also the axial gland. When we make sections of it, we see that it is formed of a connective tissue layer with some muscular fibers, both sides covered with a ciliated pavement epithelium.

How is the axial gland formed? It forms on the circular septum of the oral ring (pl. IV, fig. 16) in various ways by a single or double pedicle. Sometimes this pedicle crosses the septum and goes to be continuous with the connective tissue underlying the nerve strand (Pentaceros turritus). Whatever, it is continuous with the septum. Ludwig had seen it well, but had interpreted it in a very different way, as we see in the history section. If we place the stone canal in front, the axial gland is always to its left. It always keeps this position. From the histological point of view, it is formed by a connective tissue maze and of lymph cells (pl. VII, fig. 16). The maze of connective tissue fibrils forms a very complicated system, bordering the cavities. A large number of cells that we have already described in regard to the haemal fluid, very irregularly arranged, cover the connective tissue tracts. At the periphery, there are two kinds of contiguous cavities (pl. VIII, fig. 8 ), where the mature cells eventually arrive. Also, when we look at this part of the axial gland in vivo, we see it filled with pigmented, very amoeboid cells (pl. VII, fig. 17, $l$ ). These cross the connective tissue wall and escape outside. An epithelium formed of pavement cells cover the axial gland in part. But it is lacking in the areas where the cells cross to the outside. They are identical from the histological point of view with the undifferentiated cells of the connective tissue.

The color of the axial gland is most often brown. The color goes from clear brown to almost brown-black (Astropecten spiniulosus) or violet (Cribrella, Echinaster).

Reaching the lower surface, the axial sinus narrows greatly. From the internal side (pl. V, fig. 1) extends a very large ampulla, hidden in the interior of the body wall, located above the ampullar dilation of the stone canal $(d)$. From the internal side, it goes around the madreporite with the stone canal in the center. The internal ampulla (see pl. V, fig. 1 and 3; pl. VI, fig. 10; pl. VII, 
fig. 1) is separated from the axial sinus by a membranous septum. Its cavity does not communicate freely with that of the latter.

We shall examine now the part of the axial gland. Have nearly reached the madreporite, it sends an extension $(l)$ that perforates the wall of the sinus into the body cavity. This is the lymph gland of the body cavity that takes the most diverse forms according to the species. The axial gland continues to decend towards the madreporite, perforates the septum that separates the ampulla from the axial sinus and, crossing the entire length of this diverticula $(g$ '), attaches to the opposite wall. In a vertical section, this end is a very elongated spindle suspended nearly in the middle of the ampulla, but in reality it forms a horizontal lamella crossing the entire cavity.

In all the species I have studied, I have found the same arrangement. This ending of the axial gland is not very active and not very colored. However, it contains amoeboid cells. The ampulla being completely closed, I have not seen what could be a lymph gland. Embryology would probably show us.

I repeat that most authors have considered the lymph gland of the body cavity as a vascular apparatus from the digestive tract. Hamann has even figured ramifications from the stomach. This is a completely false idea. Injections never penetrate it. All the preceding studies show that it is simply comes from the axial gland that function to produce blood corpuscles of the body cavity.

It now remains for us a question difficult to answer: the communications of the haemal system with the exterior, sometimes affirmed, sometimes denied. It is necessary to address it with species of small size, Asterina gibbosa, for example, that has less complexity in the madreporite (pl. VI, fig. 10). Vertical sections of the ensemble show, with indisputable clarity, that the canals running through the whole plate open in the external part of the glandular sinus. I have seen very clearly the peritoneal epithelium that covers the entire blood sinus is continuous with the cuboidal cells of the madreporite canals, and these increase in size little by little up to the external epithelium. All the canals of the plate are in communication with either other. We cannot, in any figure, show the anastomoses, while we see them very well in the section by varying the microscopic view. This explains the following fact: when with all possible care, we inject a liquid by the axial sinus, the injection goes into the madreporite and then returns by the stone canal. I have found this many times in all species without exception.

I have found by sections of the madreporite canals that open directly into the axial sinus in Echinaster sepositus, various Astropecten, Luidia ciliaris, Asterias glacialis and Asterina gibbosa. In large species, Asterias glacialis and Astropectn aurantiacus, we can by injection and dissection find the openings without need of sections. We see that the fact is perfectly constant in all families.

All that I am going to describe applies only to the external side of the haemal sinus, i.e., between the stone canal and the interradial septum. Do the canals open into the ampulla containing the glandular extension $g$ '? I believe I have shown it in Asterina gibbosa and Echinaster sepositus. In the other species, we have found no pore. Liquids injected into the sinus do not enter it.

The question of whether the haemal system opens to the exterior like the water-vascular system is very controversial. Greeff, Hoffmann and Teuscher, based on injections and the latter on a section, are affirmative. But the figure Teuscher give is so inexact that it has no value for his assertion. Romanes and Ewart, Perrier and Poirier are also of this opinion, according to injections. Ludwig, taking the views of Sharpey, Tiedemann, L Agassiz and Müller, denies any communication between the haemal system and the exterior. Perrier (50) has recently taken another point of view. According to this author, "No small canals go anywhere than into the hydrophore tube. These small canals are only in fact the result of folding of the wall of the ciliated funnel, originally single, by which the hydrophore opens to the exterior, but the hydrophore 
communicates at the point where it connects to the top of the ciliated funnel, with a cavity that, I am meticulously sure of it, is the cavity of the sacciform canal." The small canals are only the result of the folding of the original ciliated funnel, I have shown it above. Moreover, this communication between the stone canal and the sinus does not signify anything important, because in the large species it is impossible to determine where the canal ends and where the madreporite begins (pl. VII, fig. 1). Perrier thus lacks precision. In small species (pl. VI, fig. 10) and even in Luidia ciliaris and Asterias we see perfectly that the stone canal is not perforated and that these are madreporic canals that open into the haemal sinus. Finally, in the figures of Lovén that represent the development of the madreporite in Ast. glacialis, we see pores that pierce the stone canal and are consequently destined for the haemal sinus. Now, it is necessary to make some restrictions. As the animal ages, the haemal pores become very thin. They are insignificant in adult Asropecten aurantiacus where injections often do not go to the exterior. We have greatly exaggerated the importance of this structure. I believe that it has no physiological influence. I can only repeat what I have said regarding the stone canal.

Genital vascular apparatus. - There remains for me to examine the second part of the haemal system, entirely in relation with the gonads. It forms at only a relatively late time, when the asteroid has reached nearly a third of its maximum size. To understand it well, it is necessary to begin with its development. I am going to take as type an Astropecten.

If we take a young Astropecten aurantiacus well before the gonads develop, we that there is on the aboral surface only the glandular sinus. The axial gland merits very well its name. It is extends outside the sinus to form the two lymph glands of the body cavity. There is no trace of the aboral haemal ring.

A young Astropecten of the same species, with $\mathrm{R}=80 \mathrm{~mm}$, shows us the following phase (pl. VII, fig. 2). On the internal suface of the body wall, we find a regular pentagon, starting from the axial sinus. From the angles of this pentagon, marked by the interradial septa, are detached two small vessels that go some millimeters along the septum and then end in a caecum. One can inject all the pentagon and the rudiments of the genital vessels by the axial sinus. These are thus hollow canals. If we make a transverse section (pl. VII, fig. 3, we can see that they are lodged in the connective tissue of the lower wall of the body and covered by the peritoneum with its usual muscle fibers (e). A pavement epithelium lines it. At the center of the canal is a round unattached cord. This cord is covered with ordinary pavement epithelium. It is formed of connective tissue and cells, some isolated and others connected in small groups. These are identical to the young cells of the axial gland, with a large nucleolated nucleus and very granular protoplasm. If we follow sections from the area of the axial sinus, we see that this cord is only an extenson of the axial gland whose various constituent parts are thus extensions in the haemal pentagon. The ovoid has right and left processes. These run the entire aboral surface and have buds in the interradius that enter the genital vessels. They form the pentagon when they meet.

I have never found intermediaries between the two phases that I am going to study because it is too difficult to procure young asteroids. But I think the haemal pentagon and the genital cord are formed and progress at the same time. The cells multiply abundantly in the genital cord, so much that we see an axis nearly completely cellular, surrounded by a connective tissue zone and a pavement epithelium (pl. VII, fig. $1, g$ ') that is always free in the center of the haemal vessel $e$ '. The formation of the gonads begins in Astropecten aurantiacus when $\mathrm{R}=8$ to $20 \mathrm{~cm}$ (in the adult $\mathrm{R}=22 \mathrm{~cm}$ ), in Astropecten hystrix when $\mathrm{R}=4$ to $5 \mathrm{~cm}$ (in the adult $\mathrm{R}=8.5 \mathrm{~cm}$ ), in Echinaster sepositus when $\mathrm{R}=2$ to $3 \mathrm{~cm}$ (in the adult, $\mathrm{R}=12 \mathrm{~cm}$ ). We see that the animal is already very well made in all relations a long time before it reaches sexual maturity. 
In an Astropecten or a Luidia, where the genital vessel is relatively long, the genital cord is relatively long, the genital cord is prolonged up to its end, gradually narrowing. Development begins at the point nearest the disk, then is extended up to the opposite end so that we see it has in the same genital vessel all the phases following each other regularly (pl. VII, fig. 7).

At a determined point, the cells multiply actively (pl. VII, fig. 4), which produces a slight swelling of the genital cord. The lifting pushes back the wall of the haemal vessel, then takes a great development while keeping the same histological makeup (pl. VII, fig. 5).

At this moment, we have a gonad more or less entirely constituted, in direct continuation with the cord that produced it, all surrounded by a haemal sinus. Then comes an important modification. A semi-lunar septum of connective tissue (pl. VII, fig. 6, $f$ ) is interposed between the wall of the sinus and the base of the gonad and the vessel on one side that is applied to the body wall. This septum is attached to the body wall. It is at its interior that will be perforated by the spermiduct and oviduct, or, to express myself otherwise, the communication between the genital caecum and the exterior. To understand this arrangement better, it is necessary to compare figures 6 and 10 from pl. VII. One is a vertical section, perpendicular to the genital vessel. The other is the projection of this same vessel on a vertical plane. The semilunar septum $f$ corresponds to the base of the gonad from fig. 10, this the point where cord $g$ "' is attached up to the point where the gonad perforates the body wall to open to the outside.

We return to the moment when the septum of connective tissue is formed. An invagination of the exterior epithelium goes across the septum to the internal cells. The exit canal is thus formed. I shall concern myself with the cellular transformations in the chapter on gonadal products.

The genital cord is still in communication with the organ it helped form. But the pedicle that connects them is soon constricted. At the same time, the form of the cord changes noticeably (pl. VII, fig. 10, 12, 13).

I shall summarize. We find in the young, immediately after the formation of the genital organs: $1^{\circ}$ A hollow pentagon from the axial sinus, that produces two genital vessels per interradius, These vessels, to each gonad, dilate into a sinus that completely surrounds it. $2^{\circ} \mathrm{A}$ cellular cord, coming from the axial gland, goes through the entire preceding apparatus and attaches at the base of each gonad.

What happens to this complex ensemble in the adult? If we make a section of the aboral pentagon (pl. VII, fig. 8), we see that the genital cord is connected to the wall of the vessel by a large pedicle of connective tissue that extends the entire length of the cord. The form of this latter is likewise modified. It is more or less deeply lobed. The cells it contains multiply greatly. They have a yellow pigment and are transformed into blood corpuscles. By following all the phases that I have described before, the genital cord thus becomes a lymph gland. This is not surprising, because it is an extension of the axial gland. While the center is formed of a mass of connective tissue and cells (pl. VII, fig. 9), the periphery has cavities very similar to those of the Polian vesicle, in which the cells are actively dividing, are full of pigment and become amoeboid (pl. VII, fig. 9, $l$ ), and from where they are finally released into the haemal pentagon.

Up to the gonads, we thus find the genital cord connected to the wall by a strand of connective tissue and transformed into a lymph gland throughout its length. When a section crosses a gonad (pl. VII, fig. 10, 12,13), the cord is in continuity with it and free of any attachment to the rest of its surface. In the adult (pl. VII, fig. 15, we can nearly always recognize the path of the vessels without injection, thanks to the the color of the cord. It has the same variation of color as the axial gland, sometimes brown, blackish or violet, and is apparent through the integument. It is impossible, when one looks at an adult, not to admit that this genital cord is the direct continuation 
of the axial gland. It is only in the family Asterinidæ, whose species are of very small size, that the genital cord is not transformed into lymph glands (pl. VI, fig. 12, $g$ ”). It contains only a few cells and keeps the undifferentiated character (compare with the cord of a young Astr. aurantiacus (pl. VII, fig. 3). As in Asterina, Palmipes and Solaster, it is necessary to have recourse to injection in order to detect the oral ring. It is never apparent in vivo because the genital cord has no color.

What could be the role of the lymph system? It is uniquely related to the gonads because very often there is no communication between the axial sinus and the aboral ring (Asterias glacialis, Astropecten aurantiacus). I have shown that very probably the lymph corpuscles absorb the soluble nutritive substances in the body cavity, in order to change them into a form resistant to diffusion. Peptones can be absorbed by the glandular aboral system. But the albumin produced by the dissolution of its cells cannot escape. They are necessarily used by the gonads that have developed very rapidly and absorb a great amount of yolk.

All the walls of the vessels are covered with a perfectly continuous ciliated pavement epithelium. Hamann does not have this point of view and has considered all the aboral ring and its dependencies as a series of hollow irregular cavities in the connective tissue. It is not so. These sinuses or vessels, as we would call them, are always perfected limited. Nowhere do they open into the interstices of the muscles of various organs. Finally, their internal wall is always covered with a continuous epithelium that with silver nitrate is a polygonal mosaic shown in fig. 9, pl. II.

We can see in vivo the circulation in the genital sinus (pl. VI, fig. 13, v’). By compressing the gonads with some precaution, we distinguish very well the various external and internal epithelial layers. I have never seen cilia in the interior of the haemal sinus. We see numerous pigmented corpuscles move slowly by amoboid movement. We can confirm the same facts in ophiuroids where all parts of the gonads are likewise surrounded on all sides by a haemal sinus. Simple examination of the organ in vivo is sufficient to demonstrate the error of Ludwig who believed that the genital cord was the vascular apparatus destined to be gonads and that it is continuous all around them.

To simplify this description, I have always spoken of the aboral vascular ring as forming a regular pentgon. But it often is very irregular. Often in Astropecten aurantiacus, we see a double vessel on one of the points of the path (pl. VII, fig. 15). This is still more characteristic in Echinaster sepositus (pl. V, fig. 10 and 11), where the aboral ring takes the form a very irregular system, we do not find two Echinaster in which is it alike. Nearly all the complications seems associated with the axial sinus. Whatever the number of vessels (pl. VI, fig. 11), the axial gland is extended into each of them. We see that it is not necessary to consider the aboral vascular apparatus as similar to the oral ring. While the latter is not changeable, the aboral apparatus varies greatly in form. This is a system, of simple form, that goes from the axial sinus to the gonads. Thus considered, it is completely homologous to that which Prouho ${ }^{6}$ found in an urchin, Dorocidaris, and which is found in the mesenteric lamella connecting the five gonads.

Physiology. - The term haemal vascular apparatus is a little pretentious. There is no blood strictly speaking, because the contents of this apparatus is identical to that of the body cavity. I have wanted simply to recall simply that it is functions for nutrition of the organs to which it goes, the epithelial-nervous strand at the upper surface and the gonads at the lower surface, thanks to the numerous lymph glands that it contains in the interior.

The fluid contained in the vessels and sinus is not moved by any current. It is simply mixed by the cilia of the vascular epithelium without a determined direction. I have tried many times to see if there was some current at the ambulacral or interradial openings. My attempts, as varied as

\footnotetext{
${ }^{6}$ Sur le system vasculaire du Dorocidaris papillata, Comptes rendus, n² 24, 16 juin 188698, page 1403.
} 
they were, were negative. With a magnifying glass, we see perfectly particles go into the openings, being mixed for a long time at the surface, then enter definitively.

After having described in general the arrangement of the vascular system, it is convenient to examine its modifications in the different families. It shows very curious things that throw a bright light on its morphology.

Asteriada. - In the studies of my predecessors, it is nearly always Asterias rubens or glacialis that they took as types. It is an unfortunate choice, because these species are very aberrant and show some special arrangements. One of them was the source of an error of Ludwig, who would certainly have had a different opinion if he had studied a simpler asteroid.

If we make an injection by the radial sinus (pl. IV, fig. 2, 4), we see that the interval between the tube feet is occupied by a vascular system that appears, at first, very different from that we have studied. It is not so. We know that in this family the tube foot pores are arranged in four alternating rows. If we consider a pair, one of the pores will approach the sinus, the other will be elongated, etc. It produces likewise a transverse sinus before each tube foot, but it is forced to circumvent the tube foot pore that is in its way. This is the only difference that exists with the asteroids with two rows. We see thus produced, side by side, two parallel vessels that are separated to surround the distal pore, following the English expression, that is in their way. A glance at figure 2 or 4 will say more than a long and painful description. At the edge of the ambulacral groove, all the vessels extend into a very poorly defined marginal sinus $(u)$, This sinus, in turn, at the level of each adambulacral pore $(o)$, has a branch that opens into the body cavity (pl. IV, fig 5, $o$ '). Hoffmann discovered this brachial system. Perrier and Poirier have corrected his description. They are the ones who have reported in the two species that I am concerned with the ambulacral openings (52). At the beginning of the arms, we see the sinus resumes the typical arrangement (pl. IV, fig. 3). The marginal sinus, after having received the first transverse vessel, is lost in the connective tissue intervals. Hoffmann has it connected with the marginal sinus of the next arm, very wrongly. In all my injections, I have seen it ends in a caecum. Moreover, this is a contradiction with what I have previously recognized in simpler species.

The haemal ring (pl. IV, fig 1) opens into the body cavity by five very small interradial openings half covered by mesenteric strands. If we introduce a very fine needle into one of them, we can easily inject the four others. Where the holes open, Hoffmann indicates a small maze of vessels. It is probable that he has injected them, but he has taken for the vessels the connective tissue strands that have a colored material, when it has gone into the body cavity.

Up to here, we find exactly the same arrangements as in the general type. We shall study now sections of the radial sinus and oral ring. A historical word is necessary. Ludwig (1878) has given a theory about the vascular apparatus, which is accepted everywhere. It is however not accurate from the point of view of interpretation. As for the facts, they have been very well observed for the most part. Ludwig, studying an aberrant type, Asterias rubens, with sections of individuals preserved in alcohol, has made the most of his material. Asteroids are poorly preserved in alcohol without special precautions. The epithelia are very delicate and, especially after decalcification, always necessary for sections, instead of a compact gland, we find only the maze of connective tissue that supports it. It is this that led Ludwig to accept vascular systems in organs that, in vivo, are obviously solid. Hamann, who has followed his theory, has made exactly the same error by neglecting studies in vivo. All that I have described as sinuses or vessels is for Ludwig a perihaemal space. The true vascular apparatus of this author is formed by the radial septa and rings, the axial gland and the genital cord. In fact, all these parts are continuous with each other and, in poorly preserved asteroids, have the appearance of a vascular system. We have seen above the 
importance of the genital cord. The axial gland that Jourdain, Teuscher and Hoffmann in asteroids and Perrier in urchins have shown to be only a gland is a lymph organ as I was the first to show. It remains for us to see what which misled Ludwig in the radial septa.

The radial septum is a very thick lamella that between the ambulacra aree large holes, always placed at the lower part. At the edge of these holes is attached the oblique septa, conjunctivo-muscular, that are connected to the walls of the sinus. When the transverse section passes by one of the holes, we have fig. 6, pl. IV. When the section passes by a non-perforated point, we have fig. 7 that shows a simple vertical septum. Ludwig has seen this arrangement very well. We see that the septum then goes to the base of the arm up to its end, complete only at it upper part that is absolutely hollow. It is this cavity that Ludwig interpreted as a haemal vessel. To study it better, here is how to proceed. With a scalpel, raise the entire bottom of the ambulacral groove. We have then a long strand, comprising the septum and epithelial-nervous layer. There is nothing to decalcify and we can make sections then as desired. We see then that the septum, limited by a thin connective tissue layer and a squamous epithelium, missing in places, is absolutely hollow (pl. IV, fig. 9). Its cavity is crossed by a large number of connective tissue strands that divide it into numerous cavities. Cells $(l)$ identical to those of lymph glands are on the connective tissue strands or are free in the cavities that they limit. We see that this septum is completely similar to a lymph gland. To be convinced of this, it is sufficient to detach it in vivo and to look at it at high magnification (oc. 2, obj. 0 with imm. Nachet). Figure 10, pl. IV, is a faithful representation. The septum is full of the usual pigmented cells, some not mature, others already amoeboid $(l)$. We see them in large numbers at certain points predisposed for their release $(d)$, veritable ruptures of connective tissue fibers not covered with an external ciliated epithelium.

In Asterias rubens and glacialis, the upper part of the radial septum is thus converted into a lymph gland. Lange, Teuscher and Ludwig has taken its cavity for a vessel, without seeing either the connective tissue tracts or cells. Perrier and Poirier are mistaken in declaring that the septum is complete and there is no trace of the vascular system described by the previously cited German authors.

The transverse sinus that goes between the tube feet always open into the upper part of the sinus and never into the lower cavity (when it appears formed of 3 superimposed canals. Fig. 6, pl. IV, shows it very clearly, contrary to Hoffmann's opinion.

The radial septum is connected to the buccal septum. Ludwig describes likewise in the latter a vascular apparatus, the haemal ring. This apparatus does not exist. The septum (pl. IV, fig. $16, s b)$ is absolutely solid, the lymph cavities of the radial septum do not go there, at least in a constant way. Sometimes the reagents contract them. It then forms at its surface some blisters of the epithelial thickenings that look like vessels. But, I repeat, this is absolutely artificial. There is no cavity that continues into the oral septum. This limits two cavities in the haemal ring, one smaller and internal that produces the glandular sinus (fig. 16, $r$ '), a larger external one that corresponds to the radial sinus and the body cavity. When we make a gentle injection by the arms, it often happens that it does not go into the glandular sinus. Communication between the various parts of the haemal system thus is not easy.

It is the same for the lower surface (pl. V, fig. 2). If we examine a fresh animal, we easily see the aboral ring and its internal genial cord $g$ ". If we make an injection into the ring, we see the liquid go before the sinus without penetrating it, then passes it and fills the rest of the haemal ring. There thus is no communication between the sinus and the aboral ring. With a careful dissection, we see the axial gland penetrate the wall of the sinus (pl. V, fig. 1), and then pass into the aboral 
ring where it forms the genital cord. Figs. 1 and 2 show clearly this arrangement. A section (fig. 3) absolutely confirms the dissectons.

The genital cord that, thus forming a complete ring, passes before the axial sinus, penetrates in turn the wall of the vessel in which it is contained and spreads out in the body cavity (fig. 1, 2, 3 ), in the form of the very irregular glandular masses $(l)$, slightly yellow, that are the lymph glands of the body cavity. In Asterias rubens, there are the same two lymph glands, but more regular than in Ast. glacialis.

We see, by this description, how it is necessary not to compare the vascular system of asteroids to that of animals higher in organization. In Asteriadæ, it is actually composed of three separate parts, all with a lymph gland that has only one or no communication among them. The first is formed of the radial sinus and the external oral ring. It opens into the body cavity. The second is composed of the internal buccal ring and the axial since and opens into the exterior by the madreporite pores. The third is formed of the aboral ring and its dependencies, uniquely in relation with the gonads. I do not say that some corpuscles do not pass from one system to the other, but the communications are extremely limited, especially in Asterias glacialis. It is not so absolute in Asterias rubens.

Echinasterida, Linckiadae. - Circulation in the arms is the general type (pl. V, fig. 7). The radial sinus is divided into two by the same thin lamella in the young, but thickens in the adult, showing perforations and oblique septa (pl. VI, fig. 1) as in the preceding. There is no trace of the lymph cavity in the radial septum.

The interradial openings are very small and very difficult to inject. All the haemal cavities communicate. We can inject the entire system by injecting a radial sinius. In Cribella oculata (pl. $\mathrm{V}$, fig. 9), the aboral ring has the form of a regular pentagon emitting the usual ten genital vessels. We inject the genital sinus easily. In Echinaster sepositus, the arrangement is completely different. I have already reported it above. The aboral ring (pl. V, fig. 10 and 11) has the form of a very variable system. I have shown a very simple one and another very complicated one. In no Echinaster have I found an absolutely regular form. In each of the branches (pl. V, fig. 5), we find a genital cord transformed into a lymph gland. This permits seeing the aboral system without injection, thanks to its color.

In a note (Comptes-Rendus, 10 January 1887, I said that the Echinasteridæ never have lymph glands of the body cavity. This is too absolute. Actually, they are extremely reduced and very difficult to find. They are reduced to some cellular masses connected by two mesenteric strands (pl. V, fig. 12, $l$ ) that leave the axial sinus and diverge to attach to the body wall. But these cells show to me in the clearest way the transformation into blood corpuscles. In some sections we can show that these masses are in continuity with the axial gland.

In Ophhidiaster Chinensis, the wall of the glandular sinus is filled with very large spicules.

Asterinida. - The septum of the radial sinus (pl. VI, fig. 8, $l$ ) is a perfectly continuous thin lamella that has scattered nuclei on its two sides. If Ludwig had examined this family he would hav better seen that this thin septum had no vascular apparatus.

The interradial openings (pl. V, fig. 13 and 14) are very large and easy to inject. In Asterina gibbosa, the gonads are placed upwards (pl. II, fig. 11), Ludwig was the first to show that genital vessels are very long, cross the interradius (pl. V, fig. 16, and then go up onto the upper surface to the gonads. The aboral ring is very often irregular. Fig. 11, pl. VI, shows the section of three rings. In each of them is a genital cord, not transformed into a lymph gland (pl. VI, fig. 12).

There are two lymph glands in the body cavity (pl. VI, fig. 9), very small and globulous, that we find easily in dissections and sections (pl. VI, fig. 10). 
Culcitidae. - The septum of the radial sinus has peculiarities of the greatest interest. In Gymnasteria carinifera, instead of being formed of a more or less thick membranous lamella, it is entirely calcareous. When we carefully detach it and observe it under the microscope, we see (pl. VI, fig. 20) that it is a long calcareous cylinder with a very dense framework. It narrows slightly up to the end of the arms.It is slightly spinous of the suface and has very numerous articulations arranged in all directions in order to follow without breaking all lthe movements of the arms. It is connected to the lower wall of the sinus by a connective tissue lamella. Although it interrupts a large part of the cavity, we find the lumen of the sinus on its sides. Coming towards the mouth, the calcareous septum that was compact from the end of the arms, dissociates so to speak. Its oral end is enclosed only by isolated calcareous plaes, very numerous to be sure. The septum of the buccal ring also contains many calcareous plates. This peculiarity of Gymnasteria seems to me to be a convincing argument. It cannot have the vascular apparatus in the partition (Ludwig), no more than the nervous system (Perrier), because this is formed of compact calcite.

Pentaceros has a very thick, simple radial septum. In Culcita, the lumen of the radial sinus is crossed by several very irregular septa bordering the cavities that open into each other. Fig 18 of pl. VI gives a good idea of this arrangement.

The interradial openings (pl. VI, fig. 15) are very large and recall those we shall see in Astropecgten. I have found two very thin lymph glands in the body cavity (pl. VI, fig. 17 and 19, l). They are supported by two mesenteric strands that are mixed at their end with cells of the digestive tract. The glandular part is a fusiform mass along the entire mesenteric strand.

Astropectinida. - I shall have little to say about this family that I have nearly always taken as a type.

In Astropecten platyacanthus, spinulosus and squamatus, the radial septum is a thin membrane, having perforations and oblique septa like those we hav aleady studied (pl. VIII, fig. 10). In Astropecten aurantiacus and hystrix, as well as in Luidia ciliaris, the septum is a thick lamella, entirely connective tissue (pl. VI, fig. 24) and continuous all along the arms. We have often spoken of vascular lacunae in the septum of Astropecten aurantiacus. No importance can be attributed to them. We have taken either as tears in the connective tissue or as artifacts in preparation (Teuscher) as lacunae. It is easy to see that they are not lined by any epithelium and, consequently, they should be considered as artifacts. In thin sections, I have always seen the the radial septum does not contain lymph cavities as in Asterias.

The interradial openings are very large (pl. VIII, fig. 3, o), locagted immediately before the interradial or odontophore support. I cannot explain how we have never seen them. We have only to raise or cut the Polian vesicles to see them without injection. They are split in two by a thin partition that is continuous with the interbrachial partition.

In adult Astropecten aurantiacus of large size, we can note nearly the same fact for the aboral ring of Ast. glacialis. The communication (pl. VII, fig. 15) between the axial sinus and aboral ring is extremely reduced. The irregularities (pl. V, fig. 20, very frequently, consists only in a doubling of one of the pentagon sides. This is nearly always on the side nearest the axial sinus. In all this family, finally, the genital cord is transformed into a lymph gland throughout its course, which immediately shows the path of the vessels.

In Luidia ciliaris, thanks to the great development of the stone canal (pl. VI, fig. 21), the axial gland is pressed against it. The glandular sinus has almost no cavity. However, it still gives a connection with injections. This species has only a single lymph gland in the body cavity (pl. VI, fig. 21, l), a large, elongated, and enclosed between two mesenteric strands. In all Astropecten (pl. VII, fig. $1,2,15, l)$, there are two glands of this kind, each hidden under a mesenteric strand. In 
section, they are greatly lobed (pl. VIII, fig. 7). They are far from reaching the point of attaching to the intestine and stop about halfway to it.

Development. - The development of the haemal system is entirely a process of organogenesis. It is perfected constituted in young asterods. The radial sinus arises by separation of the connective tissue. Also, in young animals, we see the lumen that is half obstructed by some connective tissue mesh (pl. VI, fig. 1). Little by little, these tracts are resorbed and the radial septum takes it usual form.

The radial septa thicken and are transformed with age. Thus in young aseroids, they still do not contain lymph cavities.

History. - It remains for me to report the opinions on the vascular apparatus hat have been used in science. I shall not speak here of detailed observations. They have found their place in the preceding studies.

Tiedemann (1816) describes in Astropecten aurantiacus two oral haemal rings, superimposed and separated by the oral septaum that is for him is the nerve ring. One, the more external, is his orange vessel, the other the true haemal ring.For him, the axial gland is a heart, that produces an aboral ring at the aboral surface, ten genital vessels, ten going to the radial caeca and two going to the stomach sac (Sharpey, Greeff and Hoffmann have shown that the ten vessels going to the radial caeca are only mesenteric strands).

I do not refer to the works of Della Chiaje (1825), Volkmann (1837) Müller (1854) that confirm and complement the descriptions of Tiedemann.

Jourdain (1867) considers as unique the vascular apparatus the water-vascular system. He denies completely the haemal system in spite of the preceding works. For him, the heart of Tiedemann is a simple gland.

Hoffmann (1874) made a big step regarding the question by the method of injections. He describes two rings, one oral with five radial vessels, the other aboral with ten genital vessels connected by a sinus enclosing in its cavity the stone canal and a special organ (korper drùsenformige) with contractions similar to that of a heart. Hoffmann was the first to see the vascular system of the arms. The intestinal vessels of Tiedemann are for him glands crossed by a vascular system. He suggests that asteroids do not have genital openings. As one can inject the perigenital sinus through the axial sinus, he believes that the eggs go directly into the dorsal haemal sinus and leave there to the outside by the madreporite pores.

Greeff (1871-1874) discovered that the genital cord continues to the interior of the aboral vascular circle. But he made it the way of releasing gametes that are released by interradial pores, making direct communication of sea water and the vascular system. This author began to find vessels in the different septa. For him, the heart of Tiedemann is a gill.

Perrier (1875), in his studies on urchins, shows that the heart of this animal is only a gland that he equates to a renal or excretory glalnd. About asteroids, he made a proposal according to which the aboral ring and the genital vessels are only canals for the release of sperm or eggs. This is the hypothesis of Hoffmann and Greeff.

The works of Lange (1876) and Teuscher, expecially those of the latter, led little by little to the celebrated theory of Ludwig. Teuscher shows that the axial gland is formed of fibers of colored cells. He thinks that it fills a role in the young, and it degenerates that in the adult without having any function.

Ludwig (1878) is the first who relied on well observed facts. He describes two vascular systems, one embedded in the other. The first, perihaemal, is a dependency of the body cavity. The second is the true blood or haemal system. I have already applied his theory in regard to the 
Asteriadæ. I shall not return to it. He demonstrates the the genital openings are present in all asteroids and the the haemal sinius that surrounds these organs has no communication with their internal cavity. He considers the vascular apparatus (haemal and perihaemal) as perfectly separated from the water-vascular system, to the contrary of Hoffmann and Greef who proposed a connection between the two systems in the region of the disk. For him, the axial gland is a plexiform heart, with rhythmic movements. Finally, he proposed a system of cavities in the body wall, dependencies of the perihaemal system.

Jourdain (1882) returned to the preceding opinions, describes as new the genital cord and the intestinal pseudo-vessels. He assigned to them an excretory funcgtion as well as the axial gland.

He thinks that the perihaemal system of the preceding authors is only a vast excretory apparatus for the products of the gonads and the axial gland that opens to the exterior by a pore in the peribuccal frame.

Perrier and Poirier (1882) confirm the views of Ludwig and Mùller and Troschel on the genital openings of asteroids. They clarify the opinion of Ludwig by showing the openings of the radial sinus into the body cavity of the arms.

Finally, Hamann (1885) considers the theory of Ludwig. Like him, he describes and vascular apparatus in the various septa and in the genital cord. He considers a part of the latter and the axial gland (pigmented organs) as excretory organs whose products are released through the madreporite. Likewise, he confirms the views of Ludwig about the system of cavities in the wall of the body. He accepts the two intestinal vessels of this author whose figures the ramifications on the intestine. Finally, he considers the perihaemal spaces of Ludwig as a schizocoel and the body cavity as an enterocoel. He denies all communication between the two.

Perrier (1886) recognizes in comatulids that the gonadal products develop from an extension of the axial gland. We have seen that I reported the same fact in asteroids. Prouho ${ }^{7}$ is not of this opinion for urchins. He think that the primitive genital bud forms beside the axial gland without communicating with it. I regret to find myself in contradiction with him. But the facts are so clear in asteroids where the genital cord in the adult has the identical histology and functions as the axial gland that to me there is no place for the slightest doubt.

We see how the question is full of obscurity. I have tried to to clarify it by using all means of study in the most diverse species. I stopped only when a result was constant in all the families. I have shown the true importance of the haemal system of Ludwig, the importance of the genital cord and the axial gland, which I have defined and studied its function. Likewise the intestinal vessels are only lymph glands, attached to the body cavity. Neither by injection nor by sections have I found a vascular system in the body wall. We have moreover seen in the histology of the connective tissue, which Ludwig and Hamann have taken for lacunae (schizocoel) the mass of scattered undifferentiated cells in the body wall. Finally, I have shown by injections and sections the constant communication of the true haemal system (corresponding to the perihaemal spaces of Ludwig) with the body cavity in all the species that I have studied.

Importance of the vascular system. - It is not necessary to believe, as Ludwig and Perrier and Poirier, that the vascular system of asteroids, although derived directly from the body cavity is not homologous to the vascular system of other echinoderms. Compared with urchins, for example, in the two families, we find an oral ring; radial sinuses in the arms corresponding to the haemal vessels, below the radial canals that we find in urchins. The axial sinus corresponds to the vascular system that is extended onto the axial gland in the latter; and the genital sinus and aboral ring corresponding exactly to the genital vascular system that Prouho has described in Dorocidaris.

\footnotetext{
${ }^{7}$ Sur le déloppement de l'appareil genital des Oursins, Comptes-Rendus, 3 janvier 1887, page 83.
} 
We can state that everywhere we find in asteroids a vast sinus surrounding the organs corresponding in urchins to a more or less complex vascular system. It is true urchins have a large number of vessels on the surface of the digestive tract. This is absolutely lacking in asteroids, but the fundamental makeup remains the same.

\section{Sexual reproduction.}

Asteroids have two modes of reproduction, sexual in all species and asexual in a small number of types.

Asteroids generally have separate sexes. However, the family Asterinidæ has very clear hermaphroditism in which the phases are are very remarkable. The number of males is nearly the same as that of females. There is no external differences. But the color of the gonads, yellowish white in males, red, pink or brown in females differentiate them as sooon as they are opened.

There are very probably several spawings each year. At Banyuls, I have observed it during winter, in November and December. At Roscoff, during the months of June and July. In captivity, when an asteroid spawns, it generally takes a vertical position, attaching for example to the walls of an aquarium. Then the sperm or eggs flow slowly for a very long period into the sea water.We often speak of a kind of pairing or grouping of animals. I have frequently seen the release of sexual products in various species and have never seen isolated males and females release sperm and eggs. But as they live in localized places whee they are found in large number, we can conceive that fertilization occurs in spite of these imperfect conditions. As we have seen in the study of the haemal system, the gonads are surrounded completely by a sinus. When spawning takes place, this sinus is strongly dilated and easy to inject. Its cavity nearly entirely disappears when the gonad is filled with gametes.

The gonads open to the exterior by special openings. Tiedemann thinks that in Astropecten aurantiacus, the eggs leave by openings located in the corners of the mouth. Müller and Troschel, with the same species, said the gonadal products fall into the body cavity and are released through the pores of the tube feet. I remind you of the opinions of Hoffmann, Greeff and Jourdain, who made the haemal system that path of release of the gametes. Ludwig found the true openings in several species. It is a perfectly constant fact in all asteroids. When we cannot find the openings in living animals, we easily detect them by sections.Before studying the production of the gametes, I believe it is useful to examine the various forms of the gonads in the families I have been able to study.

Astropectinnidae. - The type of the family, Astropecten aurantiacus, is well known concerning this subject. I refer to the figures of Tiedemann (see Bronn. Klassen und Ordnungen, Band II, Actinozoa) and Carl Vogt and Yung. In each interradius, we find a large number of caeca, assembled into around twenty groups. They scarcely go into the beginning of the arm. The openings are very large and simple. This are ten on each side of the interradius, one for each group of caeca. We find them easily in sections (pl. VII, fig. 10). They are located in the lower or aboral part of the arms, immediately after the marginal pieces call dorsals. The testes are whitish, the ovaries pink. The preceding description applies likewise toAstropecten spiulosous, squamatus and polyacanthus. The number of genital caeca and their volume is a little less. In Astropecten hystrix from the Red Sea, the arrangement is a little different. The genital vesicles extend up to the first third of the arm (pl. VII, fig. 7). The groups of caeca are very numerous and regularly distributed. This species is thus a transition to Luidia. 
Luidia ciliaris has likewise groups of caeca extending into the arms, nearly up to the end. They are close to each other. Each ambulacral ossicle corresponds to one or two groups. I refer to the figure of Müller and Troschel, who discovered this arrangement. The genital openings are placed as in Astropecten, all after the marginal pieces.

Culcitidae. - This family, whose water-vascular and vascular systems have many affinities with those of Astropectinidæ, has gonads also formed of numerous groups placed beside each other.

In Culcita coriacea (pl. VIII, fig. 18), the genital vesicles ( $\left.v^{\prime}\right)$ go up the interradial septa in a nearly vertical direction. All along these vessels are gonads, less and less developed toward the upper surface. The ducts for release of the gametes have a special arrangement, related to the great thickness of the body wall. We know that the internal wall of the body is marked with long slits that open into the body cavity. These divide and narrow to finally open by the papulae. We see coming from the caeca clusters of small hollow ducts that go onto the internal suface of the body wall until they reach the slits that we just described. There they go vertically to reach the external surface where they open to the exterior. fig. 19).

The connective tissue walls of the genital sinus contain many calcareous spicules (pl. VIII,

Pentaceros turritus and Glymasteria carinifera have nearly the same arrangement as Culcita.

Asterinida. - In this family, the gonads are reduced and form only a single cluster of very large caeca. In the interradius, there are thus two of these clusters, placed side by side (pl. II, fig. 13; pl. VIII, fig. 16 and 17,og). They open in the lower wall of the body, each by a very large pore, in Palmipes, Asterina Wega and Solaster. In Asterina gibbosa, first described by Ludwig, the gonads open on the upper surface (pl. II, fig. 11), but the peculiarity, unique to this famiy, is related to its special spawning. As Lacaze-Duthiers observed (19), instead of releasings its eggs into the water, Asterina gibbosa places them on nearby rocks. At the beach at Roscoff, in July, we very frequently find the spawn of this asteroid. The eggs, brownish red, arranged beside each other, form small irregular plates. The arrangement of these openings, placed on the ventral surface by which the animal moves, is evidently related to this spawning.

Müller and Troschel have describe in Solaster papposus a perforated plate (Siebplatte) for the release of the gonadal products. This figure is reproduced everywhere. This is a mistake. I have clearly seen very large interradial openings that have no appearance of a screen.

In large adults, the voluminous gonads are bright brown red. We shall see the reason for this special coloration. In young of average size, the much smaller caeca are whitish or yellowish.

Echinasteridae and Linckiada. - In each arm, near the base, are two gonads, formed of a mass of rounded caeca, occupying about a third of the arm. In Echinaser sepositus, the ovaries are brown red. In Cribella oculata, they are they are slightly less deep red. The testes are yellowish white.

The gonadal openings are easy to find in Cribella. They are locaged exactly in the interradial angle, nearly midway between the upper and lower surfaces. The two openings are separated by about $3 \mathrm{~mm}$. Those of Echinaster sepositus (pl. VIII, fig. 13) are hidden in the middle of the fold of the dermis. To see them well, it is necessary to chance on ripe specimens, whose gametes are released naturally. We then see the gonadal openings are more advanced on the arms than in the preceding species. Each opening is separated from the interradial angle by about $4 \mathrm{~mm}$.

This arrangement is still more pronounced in Ophidiaster Chinensis (pl. VI, fig. 2). The gonads, likewise forned of a mass of rounded caeca with calcareous spicules, are more advanced 
in the arm. In this figure, we see that they have not reached complete development. They are still very reduced.

I combine Lindkiadæ and Echinasteridæ for several reasons (water-vascular and vascular systems, gonads). What confirms this point of view is that these two families have at a young age the same arrangement of the gonads. In a young Echinaster whose ovary is just forming, we find two equal, clearly separated lobes (pl. VII, fig. 14). One of these lobes will develop enormously. It is the one towards the end of the arm. The other will remain much smaller. Likewise in Ophidiaster Chinensis, , the external lobe of the young gonad (pl. VIII, fig. 15) will take a much greater development than the other. This transitory phase of the gonads is perhaps fixed in other species. It is for further studies to decide.

Asteriadce. - The general arrangement of the gonads has been known for a long time. They figures that represent them are classic. The color of the ovaries varies from clear pink to a beautiful red (Ast. glacialis, variety from Banyuls).

We can note a great irregularity in the development of these organs. Sometimes in large inndividuals, $\mathrm{R}=22$ to $28 \mathrm{~cm}$, we find testes or ovaries of 2,3 , and $4 \mathrm{~cm}$, although in individuals of average size, they fill completely the arm cavity. Thee variations are probably connected to differences in nutrition.

The question of openings has been very controversial. Müller and Troschel first described them as perforated plates (Siebplate), by the pores from which the gametes were released. We are not used to seeing gonads open to the exterior by perforated plates. This fact until now has been restricted to Asterias and easily finds its explanation when we study development. In urchins, there are opennings that I shall describe as morphological, i.e., perforated calcareous plates, perfectedly determined and consant (genitals or costals). It is not the same in asteroids. There are no genital plates in the strict sense of the word. The gonads open to the outside at very different points, even in related species. We find in stars plates homologous to the genitals or costals of the urchin. But in none of the known species are there perforated genital openings. Always, these are formed instead of a papula. We know that the calcareous pieces of the body wall that Lovén calls the perisomatic tissue encloses from place to place membranous spaces that are occupied by the papulae. The gonad takes advantage of the location of these intervals to make its openings, so that they have an arrangement identical to those of the papular pores whose location it occupies. Thus in Astropectinidæ, Culcitidæ, Asterinidæ and Echinasteridæ a single papula leaves each membranous space (at least in the region where the gonads are found). The sexual opening is single. In Asteriadæ, each membranous space is divided into several parts by strong connective tissue strands, and a variable number of papulae correspond to each perisomatc interval. Also the genital openings are multiple. We see that it is not necessary to speak of a perforated plate. Fig 12, pl. VIII shows clearly that the gonad of Asterias glacialis opens into a membranous interval, completely like those that follow, occupied by papulae (br). Culcita (pl. VIII, fig. 18) is a convincing proof of the truth of my opinion. Based on what I just said, we can see a priori that Solaster papposus (pl. VIII, fig. 16, cannot have multiple pores (perforated plates of Müller and Troschel) for each gonad because the papular openings are single in this regon.

In Asterias glacialis, it is always in the second interradial peristome of the arm that we find the genital openings. They are variable in number, from 3 to 9 for each group (pl. VII, fig. 11, $d$ ). When we have seen them on an asteroid that spawns naturally, we can easily find them. We see then that they are small white tubercles, pierced in the center by an opening. They are especially apparent at the seasons of sexual maturity. 
Some have attributed to the spawn of asteroids venemous properties that it is far from having. I believe that the injuries that it has caused should be attributed to the venomous mucus that asteroids secrete for its defense that have impregnated the gonads. According to Doctor Ozenne $^{8}$, spawn applied to the skin, denuded or not, causes swelling with a severe burning sensation, numbness and reddening. I have often repeated this experiment and have never seen any of the preceding injuries.

Development of gametes. Sperm. - It remains for us to examine the formation of the gametes. To study them well, we fix them in osmic carmine for 24 hours and shred them after an equal time in distilled water.

We have seen that the gonads form from the genital cord extending directly from the axial gland. At a young age, ovaries and tests are identical. The caeca are filled with cells, usually pigmented. They have a large nucleolated nucleus, a very granular protoplasm containing some very pale yellow granules (early form of the respiratory pigment hemoxantine). I have seen in Astropecten spinulosus (pl. VII, fig. 11) cells containing much black pigment (like the axial gland of this same species). Finally, if we examine in sea water the contents of a young caecum, greatly enlarged, we sometimes see cells becoming amoeboid. The identity with typical lymph cells is thus complete.

The differentiation of the gametes begins very early. In Asterias glacialis, organs from 2.2 to $4 \mathrm{~cm}$ already contain mature gametes. We assume the organ will form a testis. There are two types to distinguish. One is that of Astropecten, the other for all the other families. In Astropecten (pl. VII, fig. 14), in the center of the genital cecum, a cavity forms. It is surrounded by a thick layer of cells $(l)$. Only cells that border the cavity will produce sperm. The others remain nearly useless for the life of the animal. If we make a transverse section towards the middle of the length of the caecum, we see first the internal wall of the genital sinus, then a thick layer of cells, and finally the sperm, bordering a cavity in which their products are developed. In the other families, we see parietal cells that are applied against the wall of the genital sinus that develop a little more than the others and are regularly aligned. All cells that remain in the center of the organ, except those that will break down and serve to nourish the parietal spermatoblasts, are lost because they will be released with the sperm. We see that, in one way or the other, there are only a small number of the original cells that are used.

The primordial cell (spermatospore of Sabatier) contains a large nucleolated nucleus (pl. IX, fig. 1). These elongate, the nucleolus divides into two, the nucleus soon follows it. The cell contains at this time two nuclei, each with with a nucleolus. Division continues thus, three, four etc. When they become very numerous, they align into two, three or four rows (pl. IX, fig. 2). We now have a mass of nucleate nuclei, all contained in the same protoplasmic mass. It is the spermatic morula or spermosphere (polyblast de Bloomfield and Sabatier). Development goes from bottom to top so that the most terminal nuclei are also the most advanced. We can follow complete development of the spermatoblast in the same spermosphere. The nuclei are more and more extuded at the surface of the cell and finish by being connected to the central part only by a pedicel that shrinks. The spermatic morula then has the form of a cluster (fig. 2), whose stalk is formed by a protoplasmic spine and the grains by nuclei surrounded by a thin clear zone of protoplasm (these are the spermatoblasts). The tail of the spermatozoid begins to be formed. It is a conical mass of protoplasm (fig. 3) that elongates more and more while thinning. The nucleolus then moves to the periphery of the noucleus. The spermatic morurla is soon made up of a well formed mass of spaermatozoids suspended by a thin pedicel with a cellular spine. The rupture of the pedicel,

${ }^{8}$ Essai sur les Mollusques considérés comme poisons. Theses de Paris, 1858. 
beginning first by the terminal spermatozoid, marks the release of the spermatozoid into the interior of the testes. We have seen that the spermatoblasts are arranged in rows. The initial nuclei of these rows are not developed into spermatozoid and remain alone, so that when the spermatoblast has finished its function, we find in its place, glued against the connective tissue wall of the testis, two or three nuclei that are not transformed. These are those that will be the place of new generations of sperm. They thus correspond to the spermataic blastophore of Bloomfield (protoblastophore of Sabatier).

The spermatozoid has not finished its development when it has left the mother cell. We have seen that the head contains two parts, the original nucleus and a small refringent grain on the border of the nucleus not far from the beginning of the tail that is the nucleolus (pl. IX, fig 5)O. When we examine living sperm, we see the nucleolus (pl. IX, fig. 5) extruded more and more on the surface of the nucleus. It then engers the surround fluid. The head of the spermatozoid is thus reduced to the nucleus. In Cribella oculata (fig. 7), the nucleolus is larger, very refringent. I do not believe in this species that the nucleolus leaves the head of the sperm. I have seen the departure of the nucleolus in all the species of asteroids I have studied. Likewise in ophiuroids, that have exactly the same modoe of development of spermatoblasts and sperm.

When we examine living sperm, at very high magnification, in addition to the sperm, some still with a nucleolus, others reduced to their nucleus, we note in the liquid small refringent corpuscles. These are evidently the expelled nucleoli and cells, very numerous in young, many less in adults (fig. 9), some with vacuoles, others filled with pigment $(j)$. These are the primordial cells not used in development. They are rarely amoeboid. I have seen this only once (fig. 8) in newly released sperm in Echinaster sepositus.

In nearly all asteroids, the head of the sperm ( 1 to $3 \mu)$ is rounded. In Asterina gibbosa it is more often triangular. In Cribella oculata, the second segment or nucleolus is developed. It has a singiular appearance. The tail is allways very long (up to $52 \mu$ ). In spite of the greater magnification (1450 time), I have not seen the duality of the tail as Olaf Jensen, Leydig and Lavalett Saint-Georges have described in various vertebrates, articulates, mollusks and worms.

The mode of development that we just described, common in asteroids and ophiuroids, is limited so far to the lower animals. The original nucleus divides many times and each new nucleus becomes a spermatozoid. In sponges, Halisarea (Schulze) and most hydrozoans, we have seen an analogous development. In higher animals (annelids, nemertiens), the nuclei from these divisions themselves divide into small nuclei. Each of them becomes a spermatozoid. There is another generation.

Eggs. - If we make a thin section of the ovary, although it only filled with original cells. We see that these cells (pl. VII, fig. 11) are in a fine connective tissue network formed of intertwined fibers connected to the thick connective tissue layer that supports the epithelium of the haemal sinus. These connective tissue fibers play a great role in the formation of the vitellus. We also find this connective tissue network in the testes. It is either resorbed or the movement of the sperm breaks it. We no longer find any trace of it in mature testes.

Some cells, especially the parietal, increase rapidly in size. These are the future eggs. The nuceus becomes naturally the germinal vesicle and the nucleolus, the germinal spot or Wagner's spot. The protoplasm loses all its pigment and fills little by littlel with vitelline granules of a very clear pink tint. In completely mature eggs (pl. IX, fig. 10), we note in addition a clear zone that surrounds the egg. This is the zona radiata or zona pellucida, a kid of vitelline membrane secreted by the egg. As the egg develops, it pushes back the connective tissue network that is applied tightly to its surface. The non-transformed primordials are likewise located on the connective tissue fibers 
so that, when we make ovarian sections, we see on the eggs some irregularly arranged nuclei. This is what made Fol and Hamann believe that the eggs of asteroids were enveloped in a follicular epithelium. It is not so.

The nucleolus is a refringent vesicle formed of very condensed protoplasm (pl. IX, fig. 14). It often contains vacuoles (Astropecten aurantiacus), filled with cellular fluid of a very pale mauve violet. Sometimes we see another nucleous take shape in the interior that is exactly concentric (Palmipes). Only in Echinaster sepositus does the nucleolus not correspond to this description. Very difficult to see (pl. IX, fig. 15), it is formed of an irregular mass of protoplasm scarcely distinguishable from the germinal vesicle.

The large germinal vesicle, always transparent, contains only some rare vacuoles (pl. IX, fig. 11, va). Most often it is homogenous. It is only in Asterias glacialis (pl. IX, fig. 10) that I have seen the protoplasmic network as clear as in the eggs of urchins. It does not appear in the other species.

The protoplasm in the egg in all families except Echinasteridæ and Asterinidæ has a very clear pink transparent yolk. It is formed of extremely small vesicles that give the mature egg a very fine dotted appearance. The transparency of the yolk has allowed Fol to make his beautiful studies on fertilization. But, in the two preceding famiies, the egg has a supplementary yolk that goes, as the other, on the conjuctive tissue network (pl. IX, fig. 13) where we see it appear in the form of yellow or clear brown vesicles, very refringent, resembling fat droplets. Because the connective tissue network is applied intimately to the surface of the egg, the yellow yolk is in immediate contact with the latter, and goes into its interior. I do not know by what process. We always see appear in Echinaster sepositus (pl. IX, fig 15) a mass of fine brown granules on one side of the germinal vesicle. Then it forms another mass on the opposite side. As yolk production continiues, these two parts join. The egg fills with brown granules so much that in the mature state it is absolutely opaque and we can no longer see even the germinal vesicle.In the Asterinidæ, the yellow yolk is arranged uniformly in the egg until it is completely opaque (pl. IX, fig 20. This supplementary yolk gives a particular coloration to the eggs and the ovaries of Cribrella, Echinaster, Asterina, Palmipes and Solaster. There is a relation between this particularity and the development of the larva. Lacaze-Duthiers has shown that Asterina gibbosa (Asteriscus verruculatus, M. and Tr.) does not have the pelagic bipinnaria. The embryo is simple, remains at the point where it was born and develops rapidly into a star. In a word, there is direct development without forming a larva. Sars made the same observation with Cribella oculata (Cribella sanguinolenta). We can conclude a priori that in all asteroids with double yolk, there is direct development. It would be interesting to see if embryogenesis will confirm this hypothesis.

As for the zona radiata, it merits the name only in Asterias glacialis, where it shows radiating streaks (pl. IX, fig. 10), especially apparent at the circumference of the egg. In other species, it is perfectly homogeneous and lacks rays. It is secreted only when the egg is completely mature, ready for spawning. In spawning Ast. glacialis, I have seen several eggs stuck together by this kind of vitelline membrane (pl. IX, fig. 11).

In the lumen of the ovary, we very often find amoboid cells (pl. IX, fig. 10), $l$ ). Some are excessively vacuolated, others have the usual aspect and fuoll of pigment. These are the primordial cells, not transformed into eggs, which have followed their development into blood corpuscles. We have not forgotten that they are derived from the axial gland that is the lymph gland par excellence. This transformation seems to me one of the best convincing proofs of the relation of the axial gland with the gonads. In asteroids, the egg is homologous to the blood corpuscle. 
How does replenishment of the eggs occur? In a ripe ovary, we hardly every find young eggs. Most are mature and ready to be spawned. But there remains, stuck against the wall and the strands the cross the ovary (pl. IX, fig.12, some primordial non-transformed cells that actively divide and that will become the new generation of eggs.

Hermaphroditism. - Hermaphroditism is very rare in echinoderms, where it is nearly always reported as exceptional. I have seen it with certainty in Asterina gibbosa. According to the figues of Ludwig, it is possible that he saw them in Asterina pentagona, but I have not been able to study this species. Finally, I have had between my hands very few specimens of Palmipes and Solaster to allow me to confirm hermaphroditism in them.

The most favoral moments to study Asterina gibbosa are the months of May, June and July. We find then, at the seashore of Roscoff, individuals of all sizes and sexually mature. In the youngest (pl. IX, fig. 16), where the gonads measure scarcely some millimeters, they are full of mature sperm. The eggs are beginning to develop. We see some very small ones stuck against the connective tissue.

In individuals of average size, the gonads are yellowish white, with numerous mature sperm (pl. IX, fig. 17 and 18). The eggs are numerous and very developed but the yellow yolk has not yet made its appearance.

Finally, the adults of great size (pl. IX, fig. 19) are absolutely females. We no longer find any trace of sperm. The developed eggs occupy along the cavity of the organ. They are completed mature, filled with opaque yolk and ready to be fertilized. We find at the same time as the eggs, some primordial cells. The connective tissue strands contain residual yellow yolk.

Fertilization has taken place. These are the young or medium-size individuals, with mature sperm that fulfill the role of males. The adults are really females.The adults form eggs again. Mature eggs develop in the individuals of average size and have the appearance of females. Finally, the very young individiuals form again spermatic cells. Thus, the individuals of largest size are always females. The young individiuals, up to a limit impossible to fix, produce sperm. As they advance in age, the eggs that they produce at the same time grow and develop. At a certain age, after spawning, they no longer form spermatic cells and the eggs begin then to fill with yello holk. I have seen the same cycle at Banyuls in the winter 86-87. The adults, $\mathrm{R}=16$ to $26 \mathrm{~mm}$, being females; the young, up to $\mathrm{R}=12 \mathrm{~mm}$, have spermatic cells and the eggs are process of development.

I have seen only one time at Roscoff, a hermaphroditic Asterias glacialis. Perfectly normal in all other aspects, it had well developed gonads containing at the same time mature eggs and active sperm.

\section{Asexual reproduction.}

Asteroids have two different modes of asexual reproduction. In the first, the asteroid divides into two equal parts. Each of these halves regrows what is missing. In the second, one arm detaches and regenerates on its own. The body regenerates the lost arm.

I am going to take as an example of the first mode of division Asterina Wega, Ed. Per. (pl. IX, fig. 21 and 23) from the Red Sea. This is a small Asterina, usually having seven arms. A single madreporite is found inan interradius. At a certain moment it forms between two interradii a lie of rupture so that one side has three arms with the madreporite and half of the mouth, the other with four arms. The digestive tract and the gonads are separated equally between them. The two parts are thus separated abruptly. We study, for example, the half with three arms (pl. IX, fig. 21 and 
22). We see that these come together in a way to close the the arm with a scar tissue. Four new arms soon bud in this free space. In the individual figured in fig. 21 , they are no more than a millimeter. These are only small calcareous mamelons scarecely separated from each other. The scales that cover them are very fine and very small. There are already some well formed tube feet with suckers, but they do not correspond directly. Equalization will probably take place with age. At the end is an unpaired tentacle formed by the elongation of the radial water canal. The last tube feet formed, farthest from the mouth, consequently, still do not have a sucker. They are simply rounded at the end. The radial sinus is wide and well formed. At the base of the arms, it has nearly its final dimensions. The nerve bands are continuous with the nerve ring of the three large arms. Development continues very rapidly up to nearly complete equality of the old and new arms. At this moment, the same phenomenon occurs so that we never find perfectly regular Asterina Wega. Often, instead of three arms, it buts more or less. We have thus specimens with 8 or with 6 arms, but the normal number is 7 .

The second mode of asexual reproduction, or radial division, madreporite is found in an interradius. At some time a line of rupture develops in two interradii so that one side has three arms with the madreporite and half of the mouth and the other has four arms and the other half. The digestive tracts and the gonads are divided equally between the two halves. The two parts separate abruptly. We study, for example, the half with three arms (pl. IX, fig. 23 and 22). We see that these come together in a way to close the wound that is immediately closed by a scar tissue. Soon four new arms form in the free space. Iin the individual shown in fig 2, they are no more than one millimeter. These have only some small scarcely apparent separated calcareous mamelons. The scales that cover them are very fine and very small. There are already some well formed tube feet with suckers but they do not correspond exactly. Equalizatoin will probably occur with ageing. At the end we see the unpaired tentacle form by an extension of the radial canal. The last tube feet formed, the furthest from the mouth, still do not have suckers. They are simply round at the end. The radial sinus is wide and well formed. At the base of the arm, the dimensions are nearly final. The nerve bands are continuous with the nerve ring of the three large arms. Development follow rapidly up to nearly complete equality of the old arms and the new ones. At this moment, the same phenomenon is repeated so that we never find perfectly regular Asterina Wega. Often, instead of three arms, it regenerates more or less of them. We thus have specimens with 8 or with 6 arms, but the normal number is 7 .

This mode of division, that I shall gladly call median, is not restricted to Asterina Wega. According to the studies of Lutken, Astrias tenuispinus (Lmk), acutispina (Stimpson), macrodiscus (Stimpson), calamaria ((Ast. muricata, Verr.) atlantica (Verr.), Stichaster albuus (Ast. problemla, Steenstrup), all in the family Asteriadæ, have median division. Kowalewsky has even seen it under his eyes in a Mediterranean species, Asterias tenuispinus that has from 6 to 8 irregular arms. One specimen of 7 arms divided into two halves, one of 3, the other of 4 . Types with six arms had two halves of 3 arms. Unfortunately, we absolutely lack details on most of the preceding species. The fact is absolutely certain only for Asterias tenuispinus and calamaria. Finally, in ophiuroids, Simroth has shown that Ophiactis virens divides equally into two equal parts.

The second mode of asexual reproduction, or radial division, is much better known. Radial division ends in the comet form. It is known, until now, only in the Linckiadæ. An adult complete Linckia has a variable number of arms. Let us consider five arms. The arms are lost by a circular line of rupture and separate from the disk. This remains with its madreporites and the stumps of the five lost arms. It replaces them little by little by regeneration. Each lost arm, in it turn, produces 
on its end four or five small mamelons. This is the rudiment of the Linckia. It forms a mouth, a disk; the arms elongate and we soon have a small sprouting asteroid by the original large one. This is the comet form. It forms new madrepories on these young arms and the Linckia is thus fully made. Although this mode of reproduction has been known for a long time, we absolutely lack details about the formation of the young arms and the new disk. I refer to the figures of Hæckel (18) for the arrangement of the madreporites in the various species of Linckia. We can state with certainty this mode of development occurs in Linckia multiporis (von Martens), Linckia Guildingii (Ophidiaster ornithopus, M. and Tr.), Linckia diplax, Lickia Ehrenbergii (Ophidiaster Ehrenbergii). In these species only, it is constant and normal. We also cite the comet form in Mithrodia clavigera (Perrier, 46), Brisinga coronata, accoding to Sars, Labidiasger radiosus, according to Studer (family of Asteriadæ) and even in Asterias glacialis, according to Schleiden ${ }^{9}$ I am particularly astonished by this fact in the last famiy. I have seen at Banyuls and Roscoff, a large number of Asterias glacialis and I have never seen the slightest indication of the comet form. The assertion of Perrier (Colonies Animales, Paris, 1881) that an isolated arm of Ast. glacialis can reproduce the rest of the animals appears to me equally rash. The isolated arms live for a very long time, up to a month, but never have I seen the least appearance of regeneration. I do not know that anyone, except for Schleiden, has ever seen the comet form in Asterias rubens or glacialis. Whatever it is, these are accidents of regeneration that do not merit the name of asexual reproduction.

\section{Classification.}

In order to have a natural classification of a family as well defined as the asteroid, it is necessary to use all the variable characters. None of them is perfect, that can serve to exclude the others. The present classifications, those of Viguier and Perrier, based exclusively on the study of the skeleton and some external characters, certainly approaches the truth. But when we know the anatomy of a large number of asteroids, there probably will be some notable changes. In my opinion, the large sections that we can establish in these animals are in no way justified by anatomy. .Viguier and Perrier adopted two large divisions. On one side, asteroids with two rows of the feet and an ambulacral mouth (see the memoir by Vigiuier for the explanation of this term, 67). The difference between these two kinds of mouth is neither as great nor important as Viguier seems to believe. When we study animals covered with their soft parts, we see that this arrangement has no influence on the organism. On the other hand, there is certainly much more resemblance between an Echinaster and an Asterias, than between an Echinaster and a Culcita. Finally, there are transitional types between the asteroids with four or two rows of tube feet. This large division thus is not natural. Similarly, division based on the presence or absence of the anus has no value. The Culcitidæ, which have an anus, have much more resemblance to the Astropectinidæ that lack it than to the preceding families.

Here is the list of species that I have studied, classified according to the affinities:

$\begin{array}{lll}\text { Asteriadæ } & \text { Asterias glacialis } & \text { Roscoff, Banyuls. } \\ & ---\quad \text { rubens } & \text { Coasts of Normandy. } \\ \text { Echinasteridæ } & \text { Cribella oculata } & \text { Very rare at Roscoff. } \\ & \text { Echinaster sepositus } & \text { Roscoff. } \\ \text { Linckiadæ } & \text { Ophidiaster Chinensis } & \text { Roscoff, Banyuls. }\end{array}$

${ }^{9}$ Das Meer, Berlin, 1874, pag. 353, fig 118. 


\begin{tabular}{|c|c|c|}
\hline \multirow[t]{4}{*}{ Asterinnidæ } & Solaster papposus & Roscoff. \\
\hline & Asterina gibbosa & Roscoff, Banyuls. \\
\hline & --- Wega & Red Sea (Aden). \\
\hline & Palmipes membranaceus & Roscoff, Banyuls. \\
\hline \multirow[t]{3}{*}{ Culcitidæ } & Culcita corincea & Red Sea (Gubbet Kharah). \\
\hline & Pentaceros turritus & ---- (Obock). \\
\hline & Gymnasteria carinifera & ---- (Obock). \\
\hline \multirow[t]{5}{*}{ Astropectinidæ } & Astropecten aurantiacus & Banyuls. \\
\hline & spinulosus & Banyuls. \\
\hline & squamatus & Banyuls. \\
\hline & platyacanthus & Banyuls. \\
\hline & hystrix & Red Sea (Obock). \\
\hline & Luidia ciliaris & Roscoff, Banyuls. \\
\hline
\end{tabular}

For the names of the species, I used those that Perrier established in his Révision des Stellérides du Muséum. It is necessary to refer to this work for synonymy.

Certainly the preceding table is not absolute. The classification cannot be considered as definitive until we know the anatomy of the different types. But the list of these species expresses perfectly the lines the connect them. The Asteriadæ is the highest family in organization in many ways. Between it and the Echinasteridæ there is a gap that I cannot fill. Obviously these two families are similar (gonads, water-vascular system) but they are poorly connected. We have seen how I have related Linckiadæ and Echinasteridæ (gonads, water-vascular system). But multiple gonads have been reported by Müller and Troschel in Linckia miliaris and Ludwig in Echinaser fallax. If this is true, these perhaps are transitional types. It is necessary to see other characeristics in order to know where to place these species.

The Asterinidæ are the most natural and most complete transition between the Echinasteridæ and the families that follow. They have gonads and a digestive tract of the first with the water-vascular system and vascular system of the second. We have seen that I have placed Solaster papposus beside Asterina. In fact, this species does not belong to the Echinasteridæ by anatomical characters although they have a skeleton similar to the latter family (Viguier, Perrier, Müller and Troschel, etc.) Solaster shows admirably the low value of an isolated character and the very limited confidence that we can accord the the skeleton to classify asteroids.

The Culcitidæ has still other characters of Asterinidæ but mostly a great affinity with the Astropectinidæ (water-vascular system and vascular system, gonads).

Finally, the Astropectinidæ has anatomical characters a little different for each genus but perfectly connected with each other. Luidia ciliaris appears to by the lowest type of asteroid while Asterias glacialis is the highest.

No character, used alone, can give a natural classification. For the skeleton, Solaster papposus is a convincing proof of this. As for the pedicellariae, not only are they not characteristic of the genera or families, but I even believe that they are variable in individuals of the same species coming from different localities (see the chapter on pedicellariae). The characters that appear to me the most constant are those taken from the water-vascular system and the gonads, provided that we examine the various changes in these organs in the family we consider.

I have believed it necessary to conserve up to now the two genera Cribella and Echinaster, although their anatomy permits combining them into one. There certainly is less diference between these two genera than between Astropecten aurantiacus and Astropecten platyacanthus or hystrix. 
But more studies are necessary to decide if the characters of Echinaster (dermal glands, aboral haemal ring) are common to all species of this genus or to the contrary if they are only accidental, in which case we must combine Echinaster and Cribella into a single genus.

Geographic distribution. - We see in the preceding table how the genus Astropecten is well represented at Banyuls. We find there in addition Astropecten subinermis, pentacanthus and ispinosus. But I have not had between my hands living species of these species.

The spicules show a very singular variation whose causes are absolutely obscure. Thus no species from the Mediterranean or the ocean that I have studied have calcite in their internal organs. In the Red Sea, the Linckiadæ and Culcitidæare truly packed (digestive tract, gonads), especially the latter family where we find spicules even in the tube feet vesicles and the Polian vesicles. Asterina Wega and Astropecten hystrix, belonging to different families, but living in the same areas, absolutely lack them.

General remarks. - Some have often looked for types of asteroids that are transitional to urchins, ophiuroids or crinoids. They have related Culcita and Asterina to urchins because of their pentagonal or globulose form. Palmipes, whose arms contain neither gonads nor radial caeca, have been related to ophiuroids, as well as Luidia and Brissinga because of the length and fragility of their arms. Perrier related crinoids to Caulaster, near to Ctenodiscus and Astropecten. These comparisons are based only on appearances. All these types obviously show characters of asteroids without the least transition to nearby groups. Viguier has likewise shown that Brisinga has nothing of the skeleton of ophiuroids. I am far from denying that are relations between the various classes of echinoderms, but I believe the types that established them have disappeared from present nature.

Finally, nothing in the various anatomical characters supports the theory of Perrier, which sees in the ordinary asteroid a colony of six individuals, a central feeding part and five reproductive parts arranged in the rays. Where are the reproductive individuals in Culcita, Palmipes, Asterina or an ophiuroid? The arms are only extensions of the disk in which are all the organs that found in the radial caeca, the gonads, etc. These are by no means appendages, as we have often said, but lateral parts of the disk, considerably developed. This quality is not astonishing. They can reproduce, in some asteroids, all the rest of the animal. The morphological value of the arms certainly is not fixed, I know this. It is very astonishing to see, in the same family, Asterina with five arms and Solaster with fourteen. Likewise, the variation in number of arms in the same species is not explained at all. In species with five arms, specimens that have six, going all the way to the mouth, have two stone canals and two madrepories (Asterias glacialis, Asterina gibbosa). All the organs follow the same structure. There are twelve gonads, twelve radial caeca etc. The morphological reason of all lthee variations completely escapes me. Perhaps one could find it by studying the development of asteroids with numerous arms, such as Solaster.

Here my task is finished. I have tried to expose as completely as possible the anatomy of asteroids, both young and adult. I would have gladly added an embryological sudy, but circumstances beyond my control prevented it. I hope later to fill this hole, because especially from the ontogenic point of view, there is much new research of the highest interest to do.

Seen and approved:

Paris, 15 May 1887.

THE DeAn OF THE FACUlTy OF SCIENCE, E. HEBERT. 
Seen and permitted to publish:

THE VICE-ReCTOR OF THE ACADEMY OF PARIS.

Paris, 16 May 1887.

GRÉARD 


\section{EXPLANATION OF THE PLATES.}

\section{PLATE I.}

\section{Appendages of the body wall.}

Fig. 1. - Crossed pedicellariae of Asterias glacialis; mag. 100 times; $a$ and $a^{\prime}$, adductor muscles; $b$, abductor muoscle; $g$, basal piece; $f$ fibrous peduncle.

Fig. 2. - Vertical section of a spine with collar of crossed pedicellariae (we have represented only half of the section); $f$, layer of connective tissue fibrils where the peduncles of the various pedicellariae are attached; $p$, pedicellariae encountred in a section; $m$, small muscle going the length of the spine.

Fig. 3-6. - Development of a crossed pedicellariae of Ast. glacialis; $f$, peduncular fibers beginning to form.

Fig. 7. - Tridactyl pedicellaria; mag. 20 times.

Fig. 8. - Another form of tridactyl pedicellaria, but younger; mag. 50 times.

Fig. 9. - Straight pedicellaria of Ast. glacialis; $a$ ', adductor muscle; $b$, abductor muscle.

Fig 10. - Half of a straight pedicellaria, whose jaws have a discoidal form.

Fig. 11. - Section of the straight pedicellaria of fig. $9 ; a$ and $a^{\prime}$, adductor muscles; $b$, abductor muscle; mag. 10 times.

Fig 12. - Epithelial covering of a straight pedicellaria; $q$, mucous cell; $m$, muriform cell; $n$, superficial nerve plexus; $f$, connective tissue fibers and undifferentiated cells forming the substratum of the pedicellaria (oc. 2 , obj. 9 with imm. Nachet).

Fig. 13. - Muriform cell of a crossed pedicellaria showing a polygonal network on its surface.

Fig. 14. - Pedicdellaia of the ambulacral groove, Gymnasteria carinifera; $a$, adductor muscle; $b$, abductor muscle; $f$, fibrous peduncle attached the pedicellaria to the calcareous pieces of the body wall.

Fig 15. - Section of a dermal gland of Echinaster sepositus: $e$, external epithelium; $f$, slit in the connective tissue fibers; mag. 70 times.

Fig. 16. - Very enlarged portion of the preceding section; $f$, connective tissue network bordering the cells; $g$, glandular cells without nuclei; $v$, vesicles pushed to the side of the cells

Fig. 17. Cells of the same gland, isolated after fixation in osmic carmine, mag. 500 times; $g$, glandular cells of all sizes, containing vesicles in the interior; $n$, free nucleus; $r$, vesicles leaving the cells.

Fig. 18. - External epithelium of the arms. Astropecten aurantiacus: $e$, cells with red pigment; $m$, muriform cell; $n$, superficial nerve plexus; (oc. 2, obj. 9, at imm.Nachet).

Fig. 19. - Ciliated spine covering the lower marginal plates of Luidia ciliaris; $r$, calcareous network supporting the spine: mag. 100 times.

Fig. 20. - Vertical section of a papula, Cribella oculata; $c$, general cavity; $l$, lacuna concentric with the papula; $p$, articulating spines on the calcareous pieces.

Fig. 21. - Top of a papula, Asterias glacialis: $e$, external glandular epitheium; $f$ connective tissue and muscle layers; $p$, peritoneal epithelium (arrow indicate direction of the current produced by the cilia).

Fig. 22. - Vertical section of a papula of Luidia ciliaris; $l$, concentric lumen of the papula.

Fig. 23. - External epithelium of a papula of Asterias glacialis; $m$, muriform cell in the granular state; $q$, mucous cell; $n$ superficial nervous netework. 


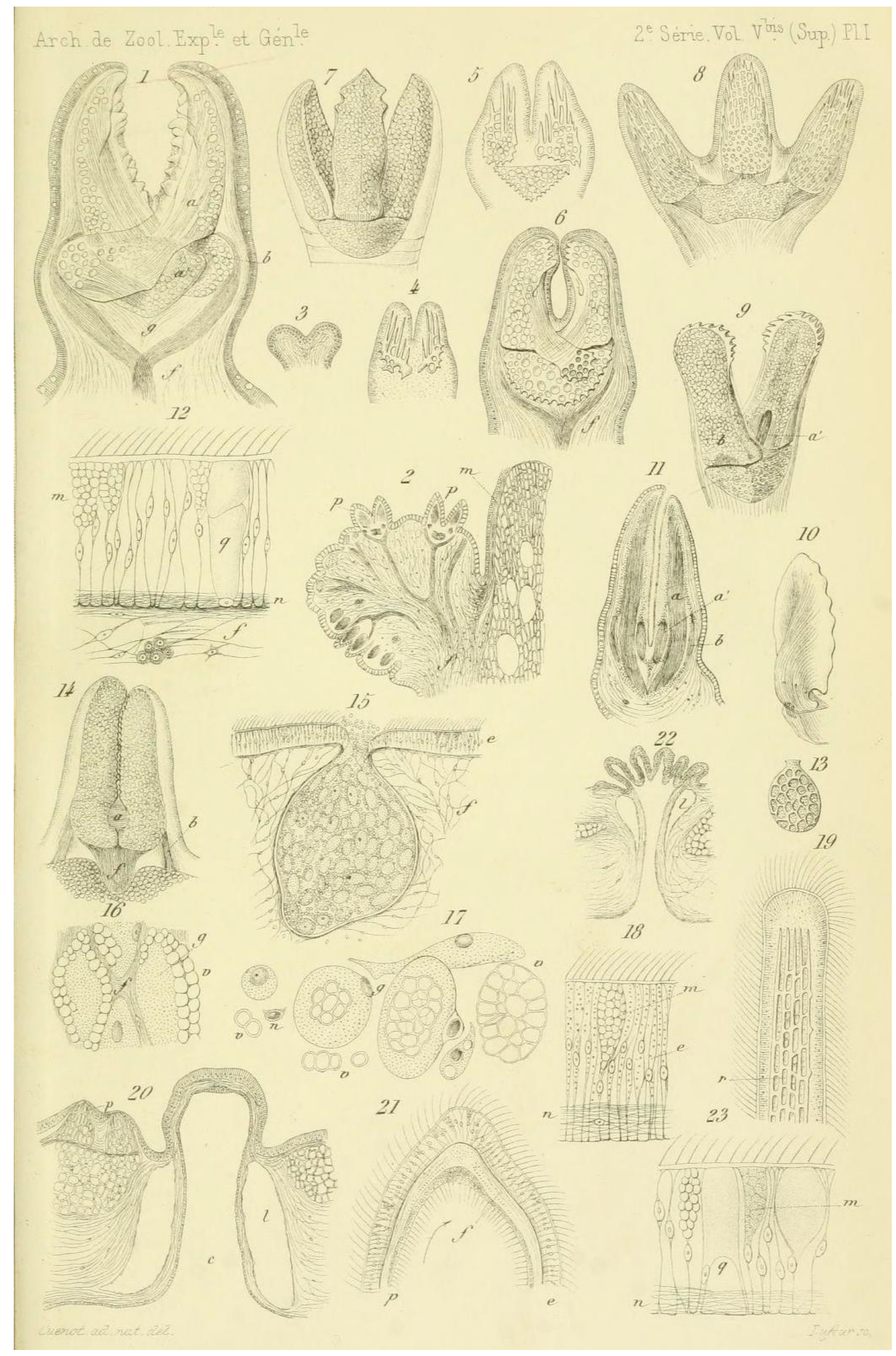




\section{PLATE II.}

\section{Connective tissue, digestive tract.}

Fig. 1. - Didactyle pedicellaria of Luidia ciliaris (Banyuls); mag. 10 times.

Fig. 2. - Undifferentiated cells of the connective tissue, cells in a cluster (straight pedicellariae of Ast glacialis).

Fig. 3. - Undifferentiated star-shaped cells, Asterias glacialis.

Fig. 4. - Elastic connective tissue fibers (tube feet of Asterias glacialis).

Fig. 5. - Elastic connective tissue fiber folded in a zigzag (straight pedicellaria of Asterias glacialis).

Fig. 6. - Connective tissue fibers (fibrous peduncle of crossed pedicellariae, Ast. glacialis).

Fig. 7. - Fibrous fundamental substance, with nucleis and an undifferentiated cell, Echinaster sepositus.

Fig. 8. - Calcaeous nework with its undifferentiated cells, Asterina gibbosa.

Fig. 9. - Peritoneal epithelium, fixed in silver nitrate and stained with carmine, Ast. glacialis.

Fig. 10. - Muscle fiber (radial cord, Ast. glacialis).

Fig. 11. - Digestive tract of Asterina gibbosa, mag 3 times; $b$, mouth; $s$, stomach; $r$, radial caecum with its pouch; $c$, stomach caeca; $a$, anus; $b$, interradial septum; $o$, gonad.

Fig. 12. - Stomach caeca of Asterina gibbosa, seen from the oral side.

Fig 13. - Lower part of the digestive tract of Palmipes membranaceus (same letters as in fig 11), mag. 3

times.

Fig. 14. - Upper part of the digestive tract of Echinaster sepositus; $o$, esophageal pouch; $s$, stomach.

Fig. 15. - Stomach caeca of Echinaster sepositus (we have kept one side of the radial caeca); $s$, opening connecting the stomach caeca and the stomach.

Fig. 16. - Villous aspect of the internal surface of the stomach ceca, Echinaster sepositus.

Fig. 17. - Stomach caeca of Cribella oculata.

Fig. 18. - Radial caeca of Cribella oculata, seen in profile and in its natural position to show the pouch that extends below it.

Fig. 19. - Stomach caeca of Asterias glacialis; one very simple, mag. 2 times, from an indiiduial with $\mathrm{R}=$ $5 \mathrm{w} \mathrm{mm}$; the other very complicated, from an adult; $s$, stomach opening.

Fig. 20. - Radial caecum of Ast. glacialis, seen by the lower surface (mag. 2 times); $p$, median pouch.

Fig. 21. - Transverse section of the stomach caecum of Ast. glacialis; $p$, peritoneal epithelium; $m$, circular muscles; $f$, connective tissue layer; $g$, glandular epitheium.

Fig. 22. - Cells from the lowest part of the stomach, Ast. glacialis; q, mucous cell; $n$, nerve layer of the digestive tract.

Fig. 23. - Cells of the stomach, seen at a great magnification; $a$, part of the cell showing the formation of digestive granules in the protoplasm; $n$, nucleus (oc. 2 , obj. 9 at imm. Nachet).

Fig. 24. - Glandular layer of the esophageal pouches of Echinaster sepositus, with numerous mucous cells.

Fig. 25. - Stomach of Cribella oculata: $p$, peritoneal epithelium; $f$, connective tissue layer with some muscle fibers; $n$, nerve layer of the digestive tract; $a$, isolated cell lacking granules and containing only the protoplasmic mesh.

Fig. 26. - Reservoir of the radial caecum, Echinaster sepositus (preparation taken towards the longitudinal half of the sac), mature cells at the side of cells in the process of developing; $n$, nerve layer. 


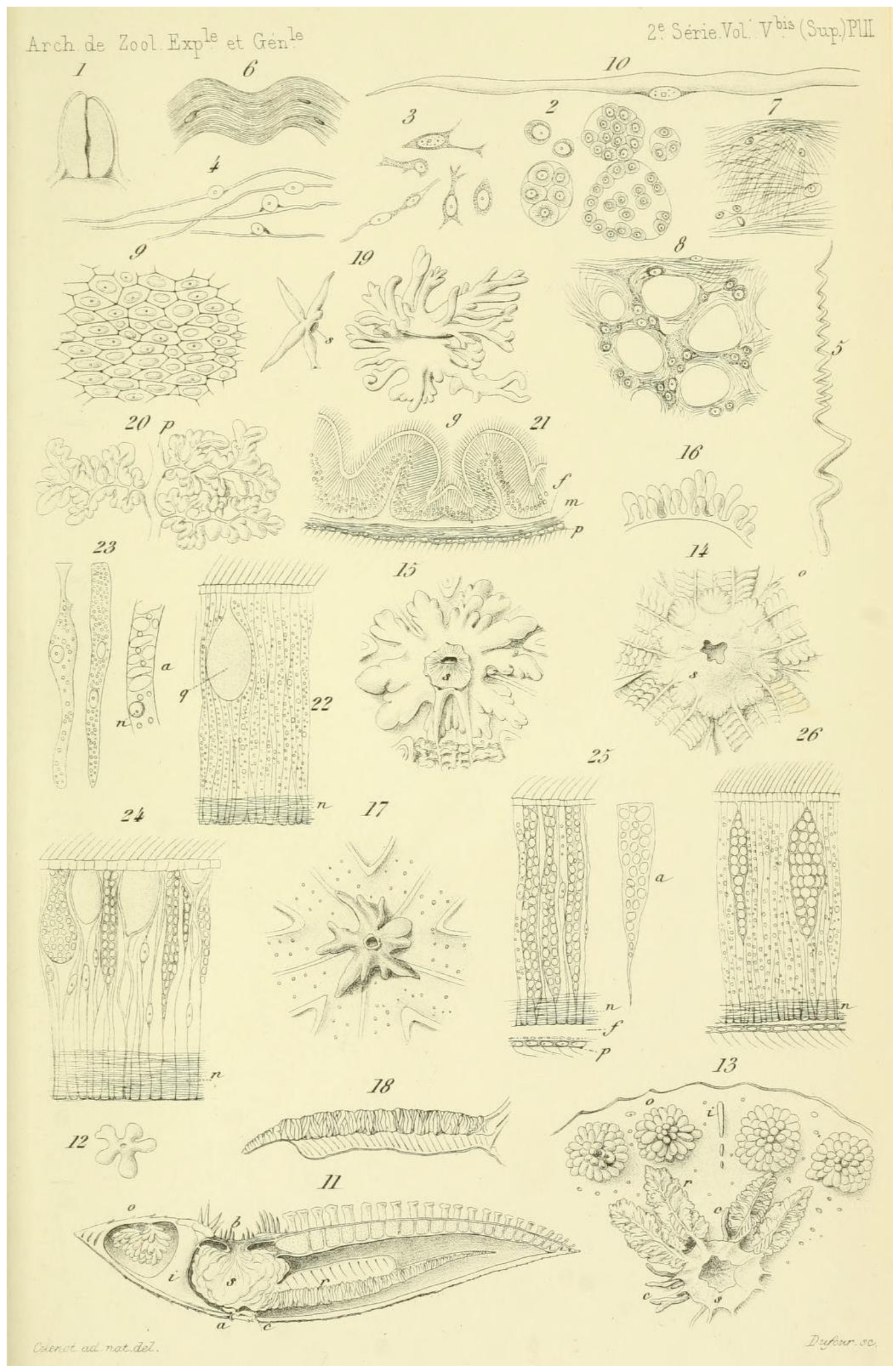




\section{PLATE III.}

\section{Digestive tract, nervous system.}

Fig. 1. - Radial caecum of Astropecen aurantiacus (osmic acid).

Fig. 2. - Stomach caecum of Asropecen aurantiacus; $n$, very reduced nervous layer (osmic acid).

Fig. 3. - Upper end of the cells of the radial caecum: $q$, mucous cell; $c$, cuticle.

Fig. 4. - Development of the stomach caeca (mag. 4 times), Astropecten aurantiacus $(\mathrm{R}=82 \mathrm{~mm})$.

Fig. 5. - Development of the radial caecum (maga. 10 times). Astr. squamatus $(\mathrm{R}=12 \mathrm{~mm})$.

Fig. 6. - Stoomach caeca of Ast. aurantiaacus.

Fig. 7. - Stomach caeca of Astr. squamatus; $m$, mesenteric strap connecting the organ to the body wall.

Fig. 8. - Stomach caeca of Astr. polyacanthus.

Fig. 9. - Stomach caeca of Ast. hystrix; $a$, false anal opening.

Fig. 10. - Spicules of the digestive tract, Culcita coriacea.

Fig. 11. - Radial nerve, Asterias glacialis (osmic carmine); $n$, nerve fibers layer with some cells; $f$, connective tissue layer; $s$, cubic epithelium of the radial haemal sinus.

Fig. 12. - Nerve cell, seen with high magnification (oc. 2, obj. 9 with imm. Nachet).

Fig. 13. - Epithelial cells of the radial nerves; $a$, in Astropecten aurantiacus; $j$, yellowish pigment grains; $b$ in Echinaster sepositus.

Fig. 14. - Tentacle and sensory cushion of Asterias glacialis, seen in profile.

Fig. 15. - End of the arm of Luidia ciliaris; $t$, tentacle; $a$, tactile tube foot.

Fig. 16. - Tentacle and sensory cushion of Echinaster seositus (same letters as in the preceding.

Fig. 17. - Ocular cup of Asterias glacialis, seen in section (osmic carmine); $c$, cuticle; $n$, nervous layer (oc. 2, obj. 9 to imm. Nachet). Lange).

Fig. 18. - Pigmented cell of the eye, of different shapes (osmic carmine); $c$, cuticle (crystalline bodies of

Fig. 19. - End of the arm of a very young Asterina gibbosa $(\mathrm{R}=21 / 2 \mathrm{~mm})$, seen from the lower surface; $t$, tentacle; $a$, tactile tube feet lacking suckers.

Fig. 20. - One of the tactile tube feet lacking suckers of Asterias glacialis.

Fig. 21. - Cells of the tentacle, Ast. glacialis.

Fig. 22. - Cells of the sucker of a tube foot, Ast. glacialis (osmic acid); $a$, isolated cell identical to the Sinnezellen of Hamann.

Fig. 23. - Top of the tube foot of Gymnasgteria carinifera (magn. 20 times); $r$, crown of spicules located on the lower surface of the sucker; $r$ ', spicules in body of the tube foot.

Fig. 24. - One of the spiciules of the tube foot, greatly magnified. 


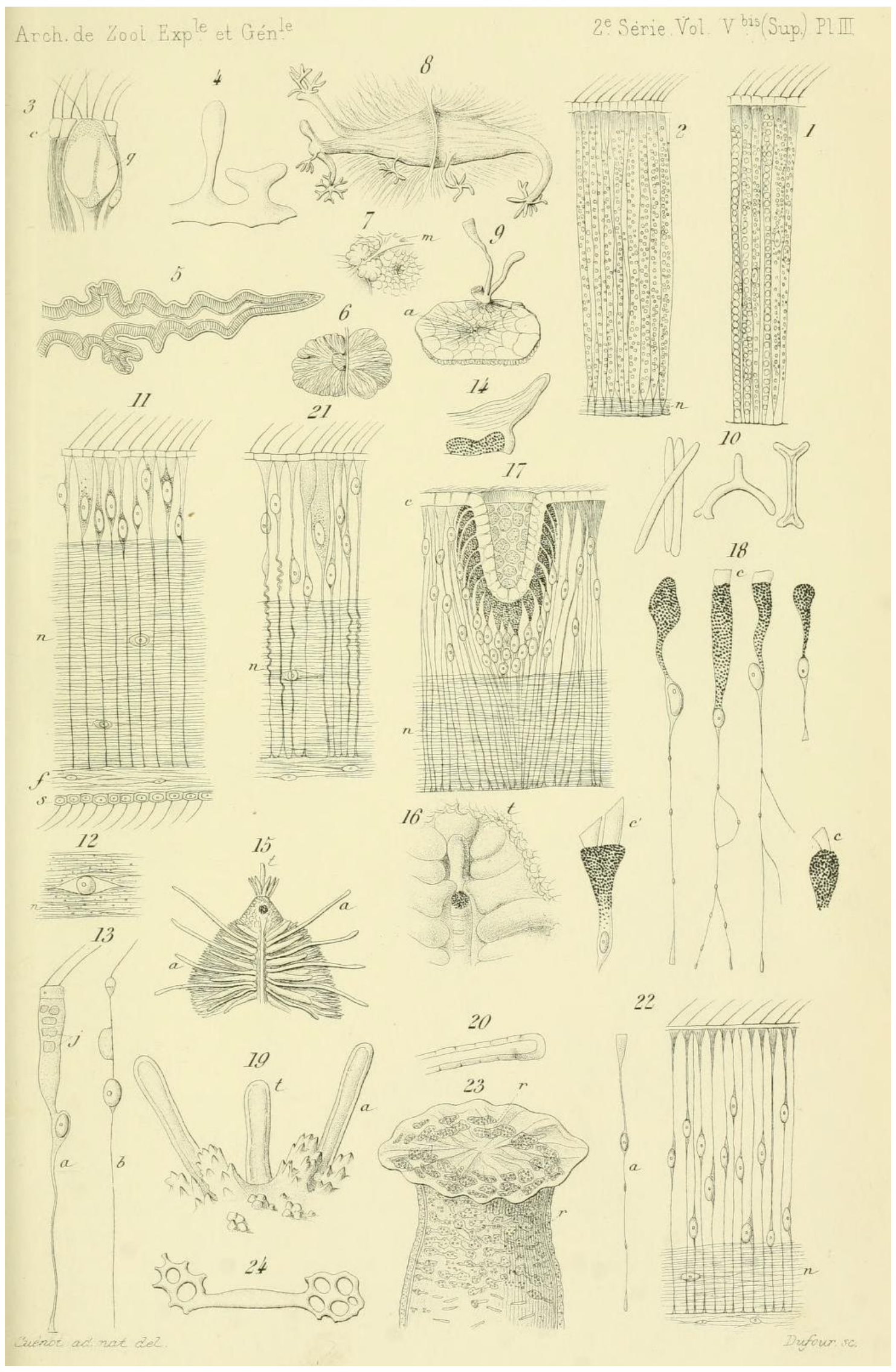




\section{PLATE IV.}

\section{Letters common to this plate and to the following.}

$a$, water ring.

$b$, radial water canal.

$c$, stone canal.

$g$, axial gland.

$g$, end of the axial gland.

$g$,', genital cord.

$h$, axial sinus (glandular sinus).

$i$, interradial septum.

$j$, yellow pigment.

$n$, epithelial nerve cord.

$o$, interradial opening of the haemal ring into the body

cavity. $o$ ', ambulacral openings.

$p$, Polian vesicle.

$r$, oral haemal ring.

$s$, radial haemal sinus.

$s$, transverse branch.

$t$, Tiedemann bodies.

$u$, marginal sinus.

$v$, aboal haemal ring.

$v$, genital vessel.

$x$, interambulacral muscle

$y$, adductoral muscle of the buccal ossicles.

\section{Water-vascular system, Haemal system.}

Fig. 1. - Internal view of the peristome, Asterias rubens.

Fig. 2. - Circulation in the arm (only two are shown that are fully injected, Ast. glacialis.

Fig. 3. - Beginning of the arm, magnified 2 times; va, vessels that go into the tube foot.

Fig. 4. - Portion of the arm, mag. 2 times, with two tube feet showing their vessels, va.

Fig. 5. - Portion of the axis of the arm, Ast. rubens; the ampullae have been partially removed.

Fig. 6. - Transverse section of the axis of the arm passing by a tube foot (mag. 12 times), Ast. rubens; $b$ ', transverse vessel going from the radial water canal to the tube foot.

Fig. 7. - Transverse section of the axis of the arm, more magnified than the preceding, cut tangentially to a tube foot; $l$, radial septum.

Fig. 8. - Transverse section of a Tiedemann body, showing the section of the secretory tubules; $f$, connective tissue; $l$, lymph cells.

Fig. 9. - Transverse section of the radial nerve cord, greatly magnified, Ast. glacialis; $e$, internal epithelium of the radial sinuis; $l$, lymph cells continuous with the interadial septum.

Fig. 10. - Portion of the radial septum seen in vivo, Ast. glacialis; $l$, lymph cells; $e$, internal epithelium of the radial sinus; $d$, area predisposed for the exit of lymph cells (oc. 2, obj. 9 to imm. Nachet).

Fig. 11. - Blood corpuscles of the body cavity: pa, small part of a plasmodium (oc. 2, obj. 9 to imm. Nachet). corpuscle.

Fig. 12. - Cells of the axial gland, prepared with osmic acid; cs, living cell, transformed into a blood

Fig. 13. - Transverse section of the stone canal of Ast. glacialis (very rare form); $k$, mesenteric strand connecting the stone canal to the wall of the axial sinus.

Fig. 14. - Section of the stone canal of a young Ast. glacialis.

Fig. 15. - Transvere section of an internal fold of the stone canal, mag. 250 times; $e$, ciliated epithelium of the canal; $f$, section of the calcareous network.

Fig. 16. - Vertical section of the peristome of Ast. glacialis, showing the beginning of the axial gland: $m$, muscle layer radiating from the esophagus; $f$, connective tissue layer; $n$ ', extension of the radial nerve on the esophagus; $r$, cavity of the glandular sinus; $s b$, septum of the oral haemal ring. 


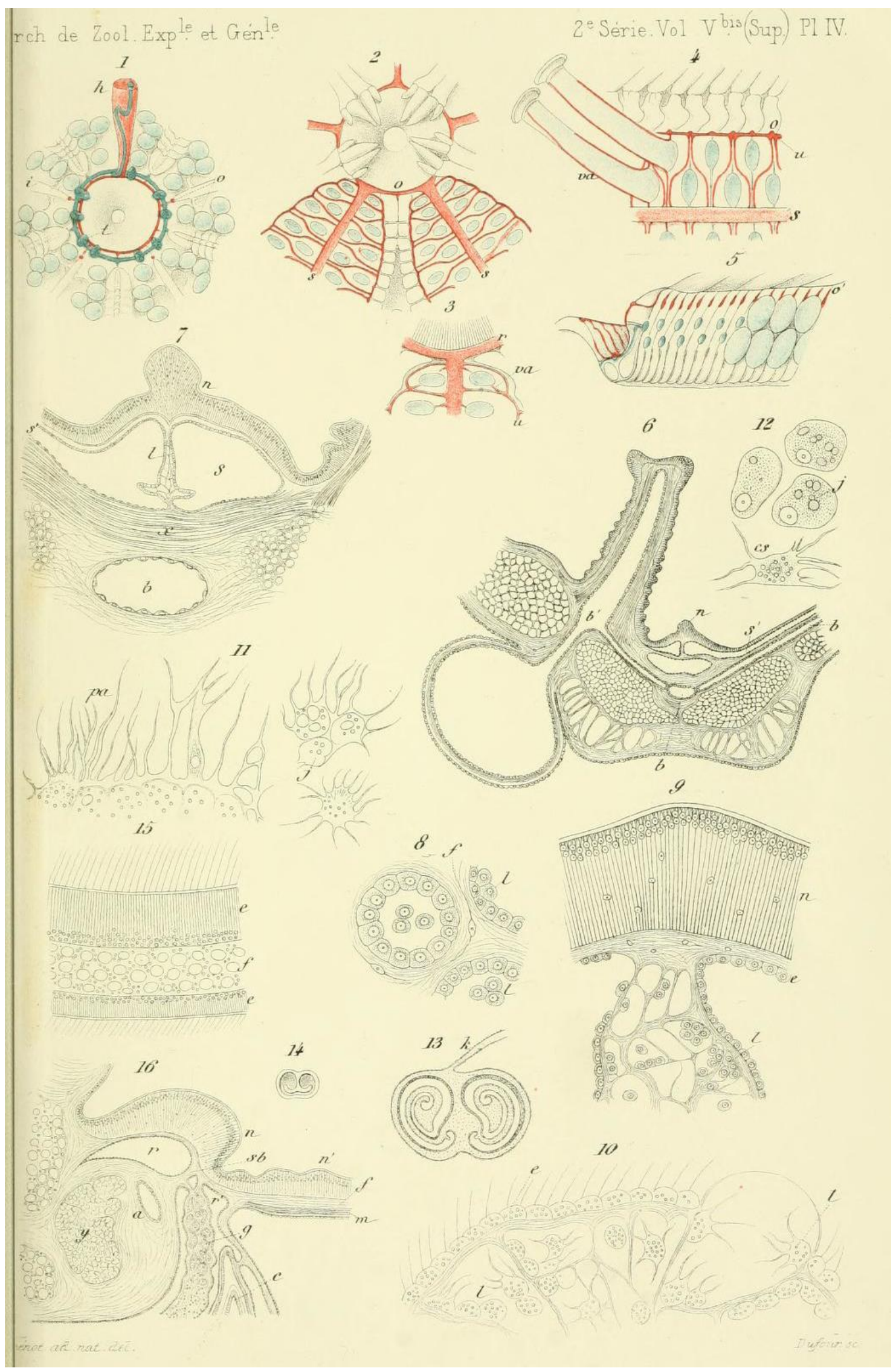




\section{PLATE V.}

Fig. 1. - Section of madreporie and adjacent parts, Ast. glacialis, after dissection of injected specimens, mag. 7 times: $m$, madreporite; $d$, dilated ampoule of the stone canal; $h$, terminal ampoule of the haemal system; $l$, lymph gland of the body cavity; $c$, spine surrounded by its collar of crossed pedicellariae.

Fig. 2. - Internal view of the lower surface of the body wall; $k$, connective tissue blade connecting the stone canal to the wall of the glandular sinus; $l$, lymph gland of the body cavity; $b r$, openings of the papulae.

Fig. 3. - Transverse section showing the continuation of the axial gland with the genital cord $g$ ”. movement.

Fig. 4. - Cells of the lymph gland of the body cavity, in vivo; one is immature; the other has amoeboid

Fig. 5. - Transeverse section of the aboral ring; $m$, peritoneal muscle fibers.

Fig. 6. - Transverse section of the sand canal, Echinaster sepositus; $k$, mesenteric tract.

Fig. 7. - Circulation in the arm, Echinaster sepositus; we have preserved a single tube foot with its haemal vessel.

Fig. 8. - Lateral view of the axis of the arm, Ech. sepositus.

Fig. 9. - Aboral ring of Cribella oculata; we have preserved two injected ovaries; an, anus.

Fig. 10 and 11. - Aboral ring of Echinaser sepositus, one very simple, the other complicated; an, anus.

Fig. 12. - Lymph gland $(l)$ of the body cavity, Echinaster sepositus.

Fig. 13. - Internal view of the peristome, Asterina gibbosa: mag. 5 times.

Fig. 14. - Interradius of Solaster papposus.

Fig. 15. - Lateral view of the axis of the arm of Asterina gibbosa: mag. 5 times.

Fig. 16. - Aboral ring of Asterias gibbosa.

Fig. 17. - Circulation in the arm, Astropecten aurantiacus.

Fig. 18. - Tube foot of Astropecten aurantiacus, with three ampullae and its haemal vessels; nat. size.

Fig. 19. - Peristome of Luidia ciliaris.

Fig. 20. - Aboral ring, Luidia ciliaris. 


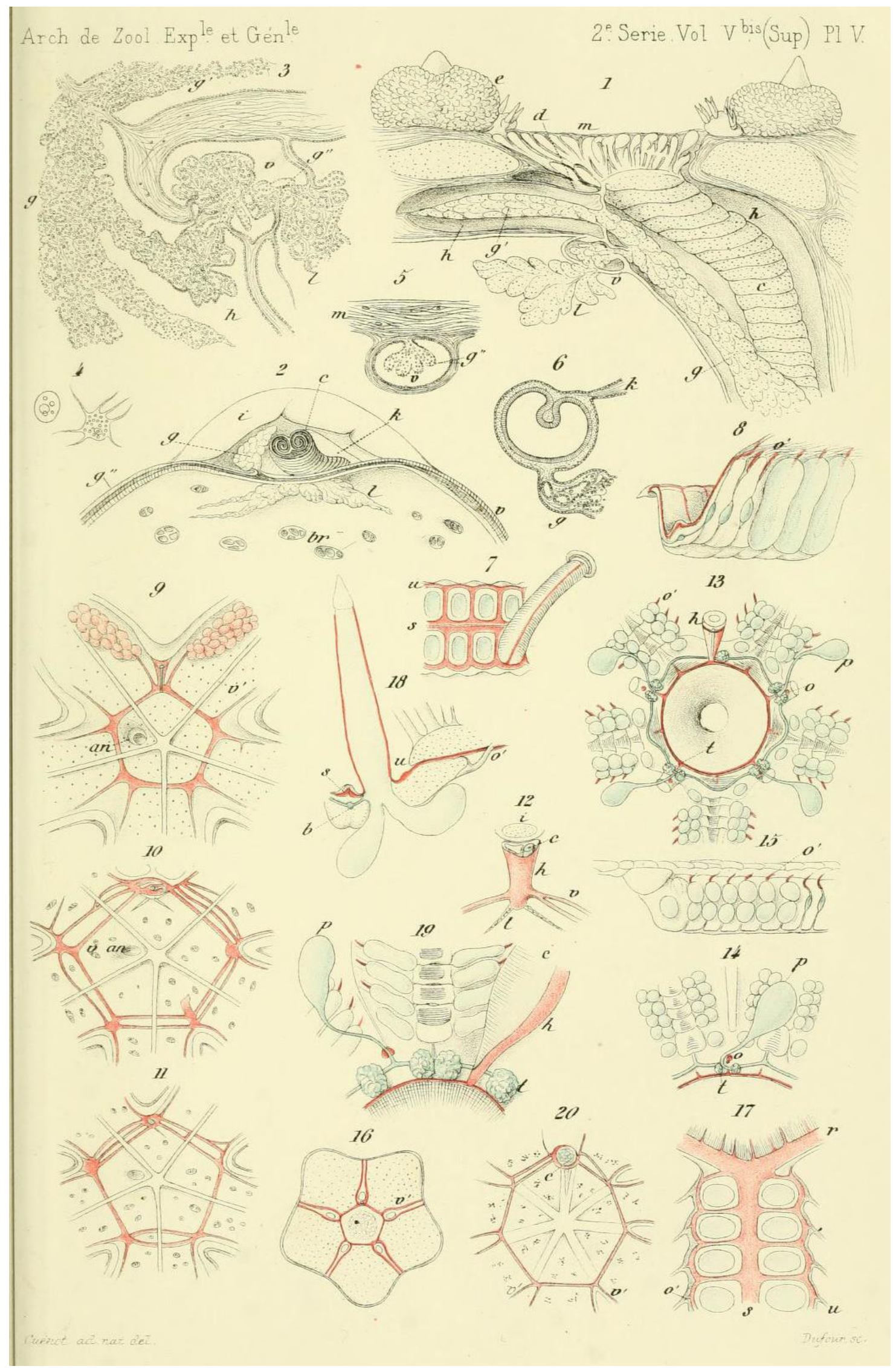




\section{PLATE VI.}

Fig. 1. - Transverse section of the arm of a young Echinaster sepositus $(\mathrm{R}=18 \mathrm{~mm})$; $l$, radial septum.

Fig. 2. - Arm of Ophidiaster Chinensis: og, gonad of small size.

Fig. 3. - Transverse section of the interradial septum corresponding to the madreporite, Asterias gibbosa.

Fig. 4. - Lower end of the stone canal in an adult of large size.

Fig. 5. - Longitudinal section of a radius showing the continuity of the septa of the haemal sinuses; $s b$, septum of the oral haemal ring, Ast. gibbosa.

Fig. 6. - Plasmodium formed in the interior of a Polian vesicle.

Fig. 7. - Portion of a Polian vesicle, seen in vivo, showing transformed cells or blood corpuscles. (oc. 2, obj. 9 to imm. Nachet).

Fig. 8. - Transverse section of the arm, greatly magnified, tangentially cutting a tube foot am; $l$, septum of the radial sinius, Asterina gibbosa.

Fig. 9. - View of the surface of the interradial septum corresponding to the madreporite plate; $l$, lymph glands of the body cavity; $b r$, opening of the papulae.

Fig. 10. - Vertical section of the madreporite and adjacent parts, Asterina gibbosa, mag. 17 times; $m$, madreporite; $l$, lymph gland of the body cavity; $h$ ', terminal ampulla- of the glandular sinus $h$.

Fig. 11. - Transverse section of the aboral ring with 3 canals side by side.

Fig. 12. - Magnified transverse section very magnified of the aboral ring, Asterina gibbosa; $m$, peritoneal muscle fibers.

Fig 13. - Genital sinus in vivo, Asterina gibbosa, with blood corpuscles circulating in the cavity; $e$, peritoneal epithelium (oc. 3, obj. 9 to imm, Nachet).

Fig. 14. - Transverse section of the radius of Palmipes membranaceus in nearly the terminal portion; $e$, lower wall of the animal.

Fig. 15. - Internal view of the peristome of Culcita coriacea.

Fig. 16. - Transverse section of the glandular sinus and the organs it contains, Culc. cor., mag. 18 times.

Fig 17. - End of the stone canal and adjacent parts, Culc. cor.

Fig. 18. - Transverse section of the radial haemal sinus, Culc. cor.

Fig. 19. - Transverse section of the stone canal of Pentaceros turritus.

Fig. 20. - Calcareous radial septum of Gymnasteria carinifera, mag. 8 times.

Fig. 21. - Stone canal of Luidia ciliais, flanked by the axial gland; $l$, lymph gland of the body cavity; og, gonad.

Fig. 22. - Very small part of the transverse section of the preceding stone canal; $e$, peritoneal epithelium; $f$, calcareous network.

Fig. 23. - Longitudinal section of the sand canal of Luidia ciliaris showing the hollow tube shape of the oral part.

Fig. 24. - Transverse section of the axis of the arm of Luidia ciliaris; $l$, very thick radial septum.

Fig. 25. — Tube foot and ampulla of Luidia ciliaris: Nat. size. 


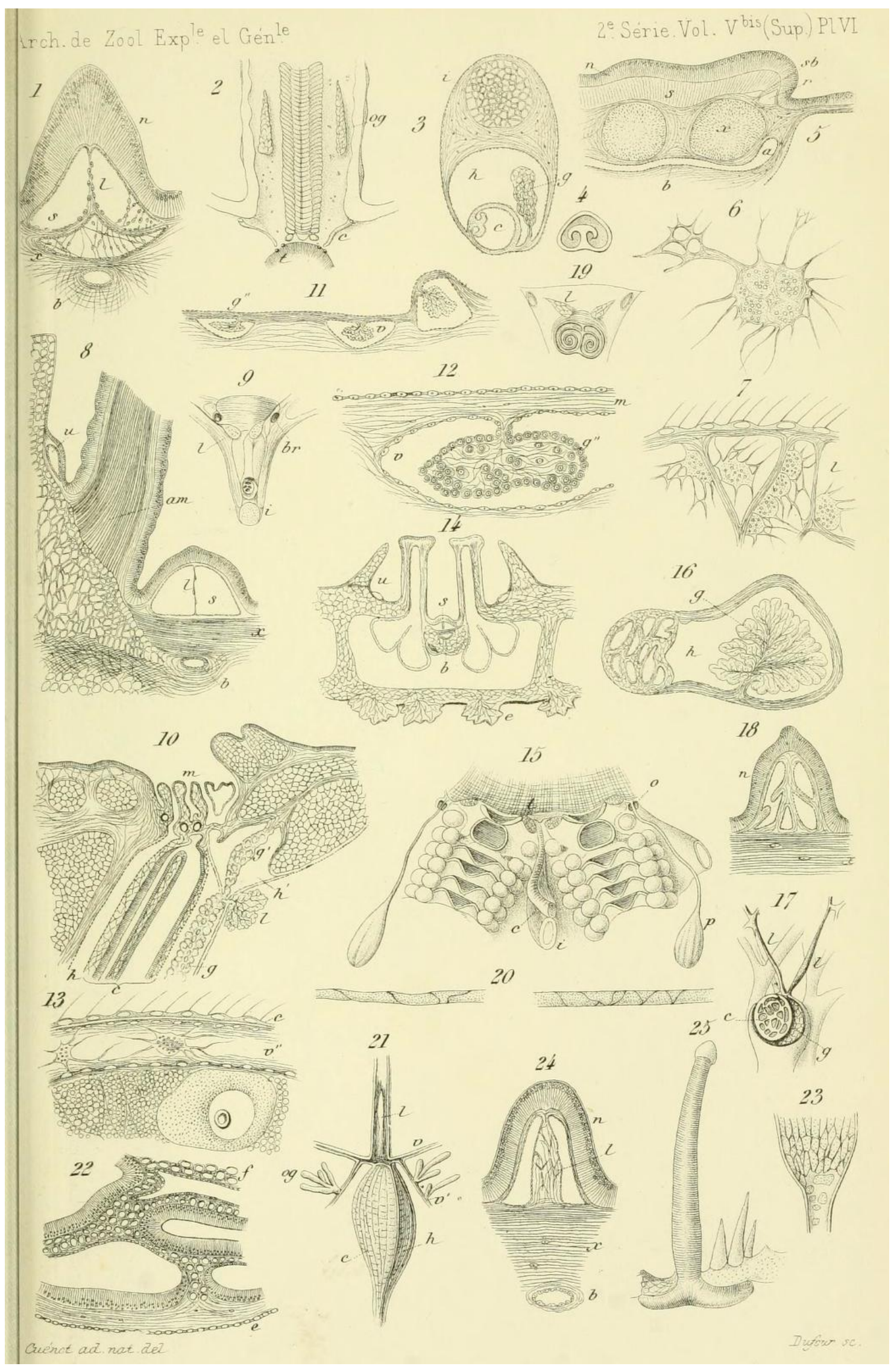




\section{PLATE VII.}

\section{Axial gland; development of the gonads.}

Fig. 1. - Vertical section of the madreporite and adjacent parts of an adult Astropecten aurantiacus after dissection, mag. 3 times; $m$, madrepoorite; $d$, dilated ampoule of the stone canal; $l$, lymph gland of the body cavity; ; $e$, paxillae.

Fig. 2. - Lower suface of an Ast. aurantiacus $\mathrm{R}=80 \mathrm{~mm}$ ) before formation of the gonads, mag. 2 times; $b r$, openings of the papulae; $c s$, stomach caeca left in place

Fig. 3. - Section of the aboral ring of the same individual in the preceding figure; $e$, peritoneal epithelium.

Fig. 4 and 5. - Formation of the gonad, Astropecten hystrix.

Fig. 6. -Development a little more advanced; $o g$, gonad; $f$, semi-lunar connective tissue strand connecting the organ and the underlying body wall.

Fig. 7. - Genital vessel and the gonads, seen in their entirety, mag. 12 times; Astr. hystrix.

Fig. 8. - Section of the aboral ring in an adultAstropecten aurantiacus; the genital cord is connected to the wall by a connective tissue strand.

Fig. 9. - Greatly magnified portion of the genital cord in an adult; $l$, cells of the cord in vivo transformed into blood cells.

Fig. 10. - Section of a testis, perpendicular to the path of the genital vessel and passing by the external opening of the testis, Astr. aur., mag. 3 times; $m$, peritoneal muscle fibers.

Fig. 11. - Peritoneal cells colored black (osmic carmine), coming from a newly formed gonad, Astropecten spinuilosus; $f$, connective tissue network supporting the gonadal cells.

Fig. 12. - Section of an ovary passing by the external opening, perpendicular to the path of the genital vessel, Palmipes membranaceus.

Fig. 13. - Transverse section of the genital cord, at the place where it is attached to the testis, Culcita coriacea.

Fig. 14. - Transvere section of the testis caecum, Ast. aurantiacus; $l$, inactive lymph cells; $s p$, spermatocytes in process of development; $f$, connective tissue layer of the haemal sinus.

Fig 15. - Axial sinus and adjacent organs, adult Astr. aurantiacus; $f$, connective tissue network supporting the lymph cells.

Fig. 16. - Section of the axial gland, Astr. aurantiacus; $f$, connective tissue network supporting the lymph cells.

Fig. 17. - Periphery of the gland seen in vivo; $l$, cells transforming into blood corpuscles; $f$, connective tissue network; $e$, cell of the peritoneal epithelium; Ast. aur.

Fig. 18. - Maturing cells of the axial gland in vivo (oc. 2, obj. 9 to imm. Nachet). 


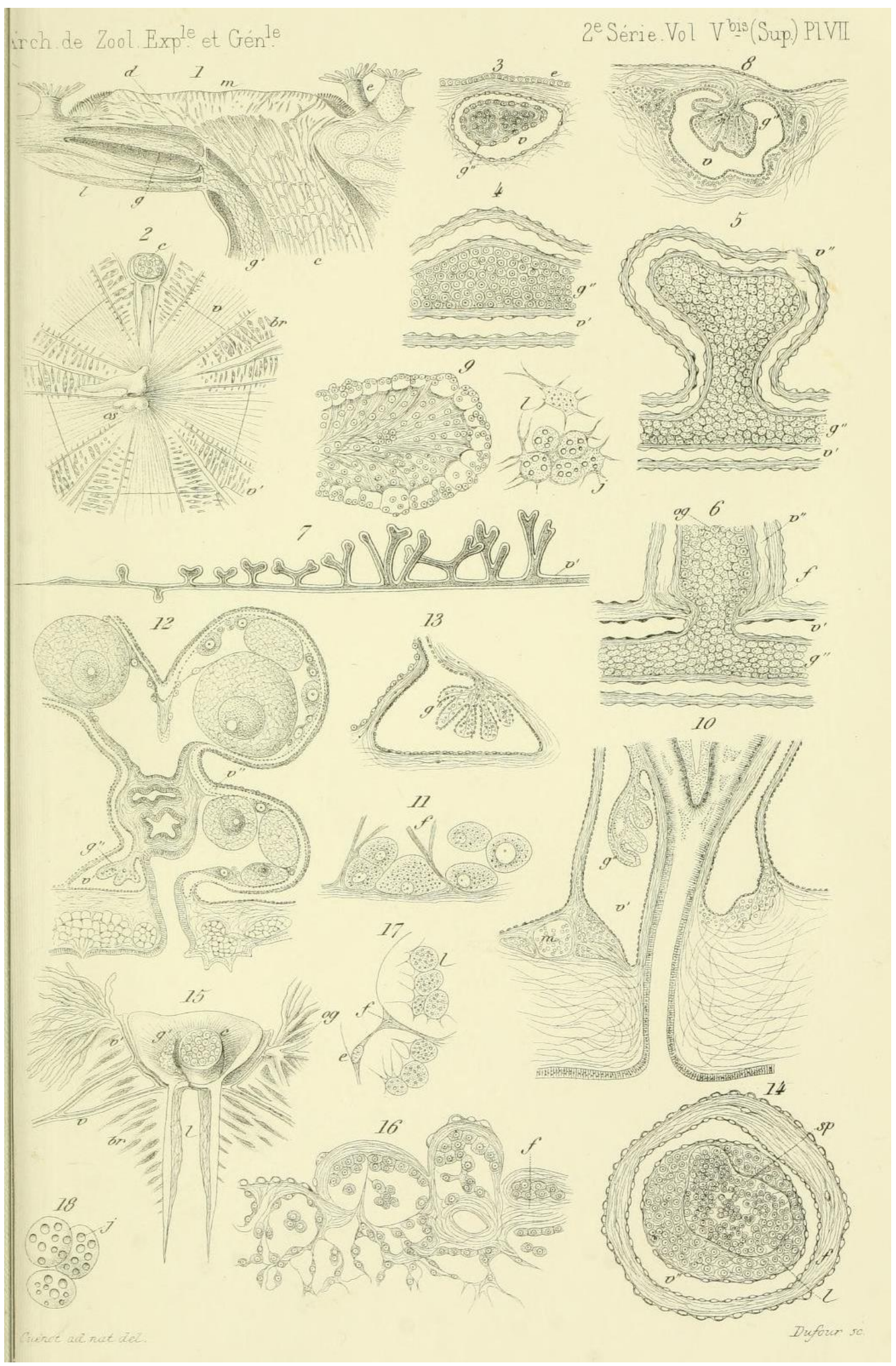




\section{PLATE VIII.}

\section{Water-vascular system, haemal system, gonads.}

Fig. 1. - Internal view of the peristome of Astropecten spinulosus, mag. 2 times.

Fig. 2. - Vertical section of the peristome of Astr. squamatus, passing by an interradial haemal opening $(o)$ and the stone canal; $l$, septum of the oral haemal ring; $n$ ', extension of the radial nerve on the esophagus.

Fig. 3. - Interradius of an adult Astropecteen aurantiacus showing four Polian vesicles ( $p$ ).

Fig. 4. - Transverse section of the axial sinus of Astr. spinulosus.

Fig. 5. - Development of the stone canal of Astr. squamatus; the smaller coming from an individual with $\mathrm{R}$ $=12 \mathrm{~mm}$; the other of an average size with $(\mathrm{R}=30 \mathrm{~mm})$.

Fig. 6. - Transverse section of the axial sinus of Astr. hystrix, in the oral part; $k$, mesenteric fold enclosing the sinus.

Fig. 7. - Transverse section of the lymph gland of the body cavity, Astr. aurantiacus; $k$, thick connective tissue strand to which the gland is attched; $m$, peritoneal muscle fibers.

Fig. 8. - Periphery of the gland seen in section, at a very great magnification; $l$, lymph cells; $f$, connective tissue network; $z$, enigmatic yellow body (zoochlorella?).

Fig. 9. - Transverse sction of a Polian vesicle, Astr. aur., mag. 50 times; $e$, peritoneal epithelium; $m$ ', longitudinal muscle fibers; $f$, connective tissue layer; $m$, circular muscle layer, $l$, glandular part of the vesicle.

Fig. 10. - Transverse section of the axis of the arm of a young Ast. squamatus $(\mathrm{R}=12 \mathrm{~mm}) ; l$, radial septum; $m$, section of the wall of the tube foot; $b^{\prime}$, intersection of the tube foot and the transverse vessel coming from the radial canal $b$.

Fig. 11. - View of the external surface of an interradius in Asterias glacialis; $d$, group of genital openings (riddled plate of Müller and Troschel); $b r$, papulae.

Fig. 12. - View of the internal surface of an interradius of Ast. glacialis; $d$, gonoduct of the rudimentary gonad $o g ; b r$, openings of the papulae.

Fig. 13. - Testis of Echinaser sepositus, seen in profile; $d$, gonad opening; $I$, interradius.

Fig. 14. - Very young gonad if Echinaster sepositus $(\mathrm{R}=33 \mathrm{~mm})$, mag. 7 times.

Fig. 15. - Development of the gonad of Ophidiaster Chinensis, of the same individual, mag. 7 times.

Fig. 16. - Lower surface of Solaster papposus showing the ovaries $o g$, and their single openings, $d$.

Fig. 17. - Gonads of Asterina Wega.

Fig. 18. - Lateral view of an interradius of Culcita coriaca; $d$ ', gonoducts of the testes $o g$; $b r$, openings of the papulae, nat. size.

Fig. 19. - Calcaraeous spicules of a testis of Culcita coriacea. 


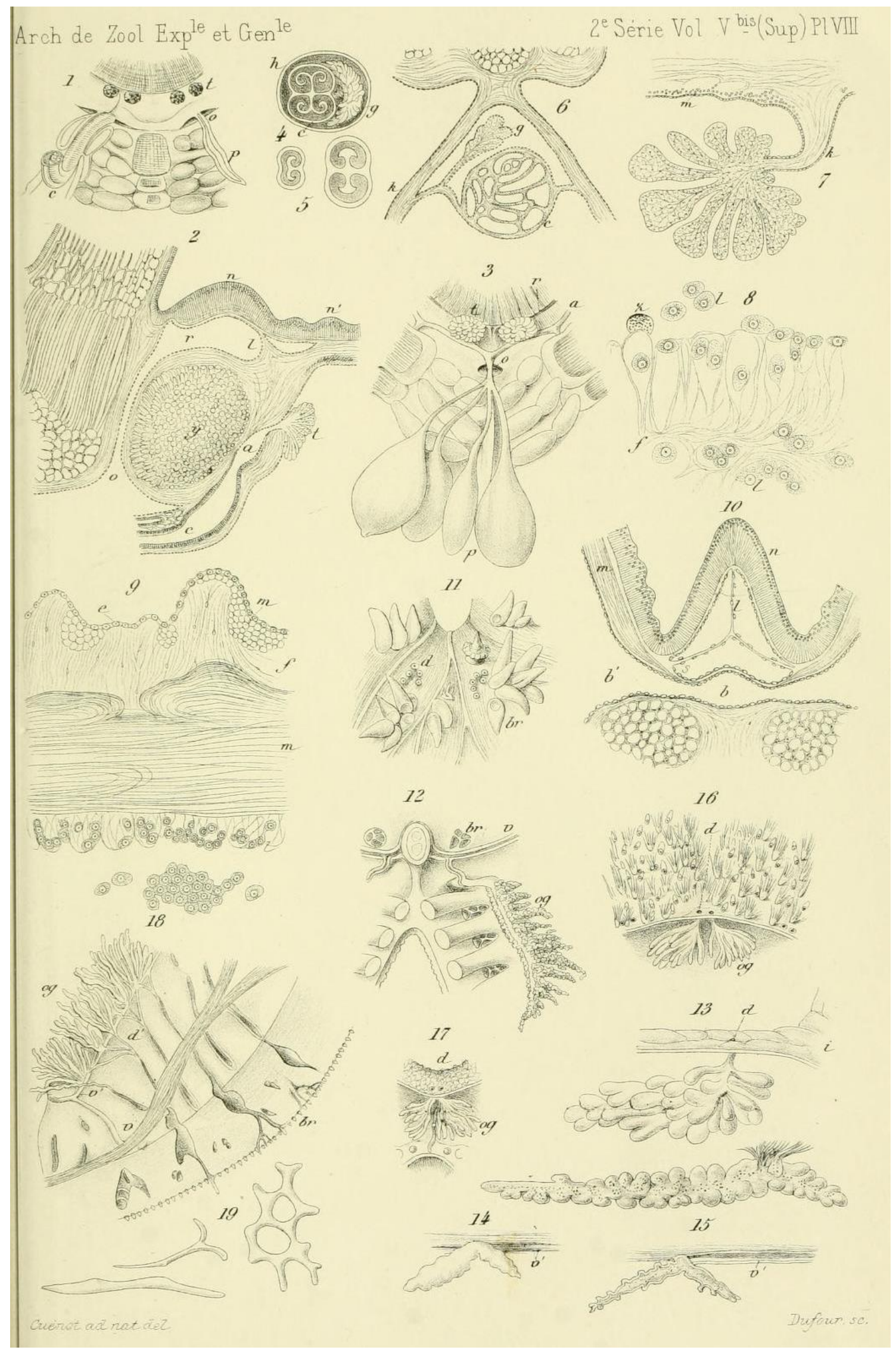




\section{PLATE IX.}

\section{Development of gametes. - Reproduction.}

Fig. 1. - Cells of the testis, showing the various stages of segmentation of the nucleus, Ast. glacialis.

Fig. 2. - Spermatic morulas at various stages of development, Luidia ciliaris (osmic acid).

Fig. 3. - Development of sperm, Ast. glacialis (osmic carmine).

Fig. 4. - Very enlaged portion of a section of the testis of a young Astropecten spinulosus; $l$, inactive lymph cells; $s p$, cells of the testis at various stages. Nachet).

Fig. 5. - Sperm in vivo of Astr. aurantiacus showing the expulsion of the nucleolus $x$ (oc. 2 , obj. 9 to imm.

Fig. 6. - Sperm in vivo with a nucleolus, of Asterina gibbosus.

Fig. 7. - Sperm in vivo, very magnified, of Cribella aculata, with a nucleolus.

Fig. 8. - Lymph cells, one of which is amoeboid, released with the sperm by an Echinaster sepsitus.

Fig. 9. - Primordial cells with pigment; $j$, inactive, found in the lumen of mature testes (Astr. aurantiacus, Cribella oculata).

Fig. 10. - Mature egg of Asterias glacialis, with vitellogenic network, $f$, and primordial amoeboid cells $l$; $m r$, vitelline membrane (zona radiata). vesicle.

Fig. 11. - Spawned eggs of Ast. glacialis, together with their vitelline membrane; $v a$, vacuole in the germinal

Fig. 12. - Section of an ovary of Ast. glacialis; f, vitellogenic connective tissue network; $l$, oogonia cells that will produce eggs.

Fig. 13. - Portion of the vitellogenic connective tissue network of Asterina gibbosa, very magnified; $g$, vesicles of yellow yolk.

Fig. 14. - Germinal spot of a mature egg of Astropecten aurantiacus, mag. 400 times; va, vacuoles.

form.

Fig. 15. - Deposit of yellow yolk $q$ in immature eggs of Echinaster sepositus; $t$, germinal spot of uncertain

Fig. 16. - Gonad of a very young Asterina gibbosa containing mature sperm beside scarcely formed eggs.

Fig. 17. - More developed gonad of Asterina giosa; mature sperm with developed eggs.

Fig. 18. - Transverse section of a gonad in the preceding stage; $f$, vitellogenic connective tissue network; $l$, non-transformed cells; $s p$, cells of the testes. yellow yolk.

Fig. 19. - Transverse section of an organ of a completely adult Ast. gibbosa, containing only eggs with

Fig. 20. - Spawned egg of Asterina gibbosa, made opaque by yellow yolk; $m v$, vitelline membrane perfectly homogeneous and transparent.

Fig. 21. - Asterina Wega (nat. size) with 4 arms that are beginning to be formed. The arrow indicates the interradius where the madreporite is found.

Fig. 22. - Preceding individual showing the new arms, magnified 10 times; ra, radius.

Fig. 23. - Asterina Wega seen by the lower surface; one has 8 arms, the other 7 (nat. size). 


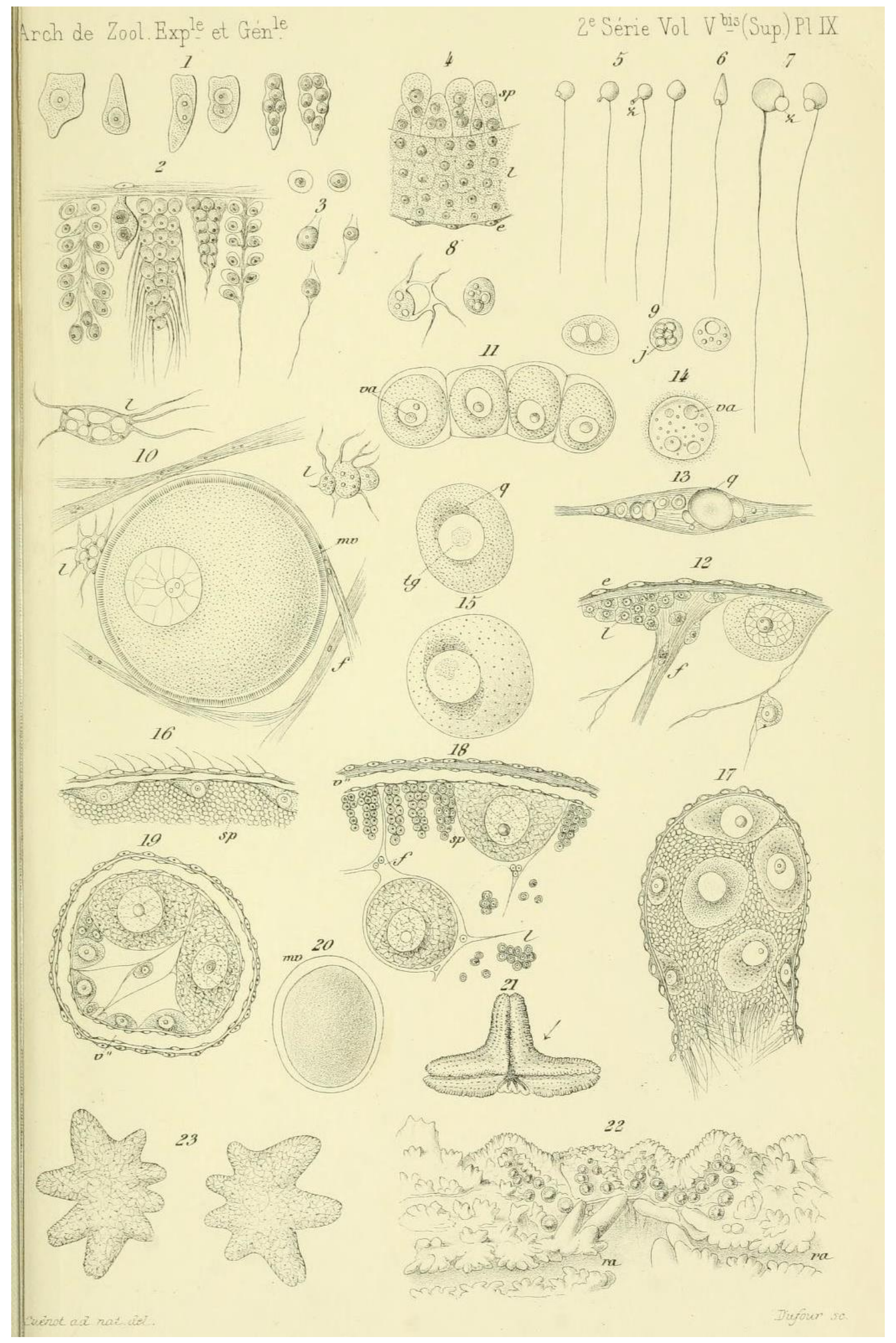

